\title{
Bureaucracies for development: oxymoron or reality? : studies on state capacity in challenging governance contexts
}

Citation for published version (APA):

Cingolani, L. (2014). Bureaucracies for development: oxymoron or reality? : studies on state capacity in challenging governance contexts. [Doctoral Thesis, Maastricht University]. Maastricht University. https://doi.org/10.26481/dis.20141029lc

Document status and date:

Published: 01/01/2014

DOI:

10.26481/dis.20141029lc

Document Version:

Publisher's PDF, also known as Version of record

Please check the document version of this publication:

- A submitted manuscript is the version of the article upon submission and before peer-review. There can be important differences between the submitted version and the official published version of record.

People interested in the research are advised to contact the author for the final version of the publication, or visit the DOI to the publisher's website.

- The final author version and the galley proof are versions of the publication after peer review.

- The final published version features the final layout of the paper including the volume, issue and page numbers.

Link to publication

\footnotetext{
General rights rights.

- You may freely distribute the URL identifying the publication in the public portal. please follow below link for the End User Agreement:

www.umlib.nl/taverne-license

Take down policy

If you believe that this document breaches copyright please contact us at:

repository@maastrichtuniversity.nl

providing details and we will investigate your claim.
}

Copyright and moral rights for the publications made accessible in the public portal are retained by the authors and/or other copyright owners and it is a condition of accessing publications that users recognise and abide by the legal requirements associated with these

- Users may download and print one copy of any publication from the public portal for the purpose of private study or research.

- You may not further distribute the material or use it for any profit-making activity or commercial gain

If the publication is distributed under the terms of Article $25 \mathrm{fa}$ of the Dutch Copyright Act, indicated by the "Taverne" license above, 


\section{Bureaucracies for Development:}

\section{Oxymoron or Reality?}

Studies on State Capacity in challenging governance contexts

\section{Luciana V. Cingolani}

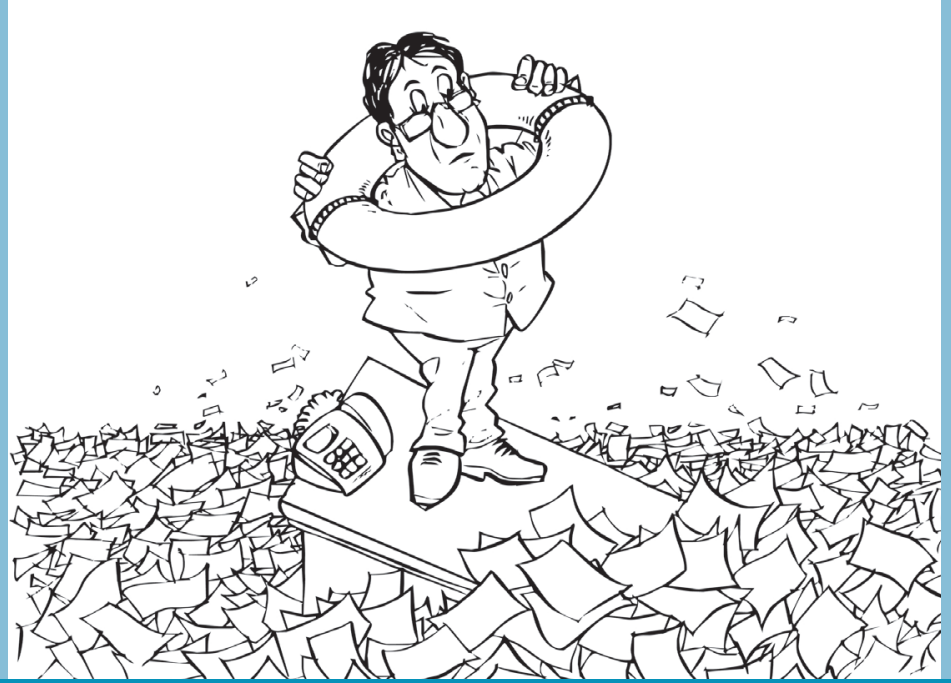




\section{Bureaucracies for Development: Oxymoron or Reality?}

Studies on State Capacity in challenging governance contexts

\section{DISSERTATION}

to obtain the degree of Doctor at the Maastricht University, on the authority of the Rector Magnificus Prof. Dr. L. L. G. Soete in accordance with the decision of the Board of Deans, to be defended in public on Wednesday 29 October 2014, at $14.00 \mathrm{hrs}$.

by Luciana V. Cingolani 


\section{Promoter:}

Prof. dr. Thomas Christiansen

\section{Cosupervisor:}

Dr. Kaj Thomsson

\section{Assessment Committee:}

Prof. dr. Adam Szirmai (Chairman);

Dr. Lutz Krebs;

Dr. Jan H. Meyer-Sahling, University of Nottingham;

Prof. dr. Steven van de Walle, Erasmus University Rotterdam. 
To Alex and our little Lara 


\section{Acknowledgements}

As everyone in the academic industry knows, writing a dissertation is nothing but a collective process masked under an individual effort. I would like to commence by thanking the members of the Assessment Committee for dedicating substantial time to evaluate and help improve this book: Prof. dr. Adam Szirmai, Prof. dr. Steven Van de Walle, Dr. Lutz Krebs and Dr. Jan-Hinrik Meyer-Sahling.

I am also immensely grateful to my promoter Thomas Christiensen and my supervisor Kaj Thomsson for their guidance, patience and priceless time. Thanks to Kaj for being fully and actively involved in my Phd process from beginning to end, and for the fruitful ideas that always emerged from our meetings. Thanks to Thomas for believing in my work at all times, and the (very necessary) boosts of confidence this translated into. The three of us have different backgrounds and interests, and we had to step out of our comfort zones to make the research go forward. I am particularly proud and grateful for this collective effort.

I would like to highlight the role of the management of both UNU-MERIT and the School of Governance in providing a wonderful environment to work in. Thanks to Mindel van de Laar for a great deal of trust and flexibility. Also, the unbreakable professionalism of people like Eveline in de Braek, Herman Pijpers, Eric Engelen and Howard Hudson made everything easier on a daily basis. Thanks in particular to Eveline for acting as a sort of 'academic midwife' towards the last and most exhausting part of the Phd process.

My gratitude is also extended to my colleagues and counterparts in the Project on Institutions and Long-Term growth funded by the French Development Agency (AFD): Bart Verspagen, Franziska Gassmann, Adam Szirmai, Denis de Crombrugghe, Kristine Farla, Biniam Bedasso, Richard Bluhm and Samyukta Bhupatiraju. I learnt a great deal from and with them. Thanks also in particular to Nicolas Meisel and Thomas Roca from AFD for their enormous dedication when reading and re-reading my drafts. This was a luxury that not every Phd fellow gets to enjoy.

Luckily, there are many colleagues who helped in my development as a re- 
searcher, and with whom I had very productive exchanges. Thanks to Bo Rothstein, Carl Dahlström, Marina Nistotskaya and Marcia Grimes from the Quality of Government Institute and their kind invitation to present one of the papers at their institute. I am also grateful to Jörg Faust for his invitation to present at the German Development Institute (DIE), and to Luis Camacho, Armin von Schiller, Lili Banholzer, and other seminar participants for their fantastic feedback. To Carlos Scartascini for his support and our insightful talks, and to Sebastian Dellepiane for our common concerns and ideas on Argentina. To Saskia Ruth, Maria Spirova, Frank de Zwart, Eva Wegner, Julia Fleischer, Jaree Pinthong, Francesco Stolfi, Anka Kekez Kostro and other participants at the ECPR Joint Sessions on Clientelism. To Laurenz Ennser-Jedenastik and James Melton at EPSA. Thanks also to Niamh Hardiman from University College Dublin, Michelle D'Arcy from Trinity College Dublin, Christiane Arndt from the OECD, and to Mary Shirley, Alexandra and Lee Benham, Scott Wallsten and Dean Lueck from the Ronald Coase Institute.

More than anything, I am indebted to my family and friends. Special credit goes to my parents for being as supportive as always, perhaps this time understanding that I had to leave for a long time. Thanks to my sister Ana, for providing an excellent example of how a Phd can be the start of a strong and consistent career, where research contributes to society. At the same time, thanks also to my brother Ernesto for exemplifying that a Phd is just a Phd, and can as well be the start of a complete career shift. We are all ok with our brother Lisandro not having a Phd, although it must be difficult...

I am also immensely grateful to my soulmate Alex and our most precious new arrival Lara. Thanks for the joy and happiness that accompanied the ending of the Phd. Thank you for being smart, cool, generous, and a list of adjectives that would be embarrassingly long. Thanks also to my parents-in-law and Lena for being sweet and welcoming every time.

A lovely and wonderful group of friends made the Phd experience unforgettable. My heart is grateful to Irina, Patricia, Ilire, Andrea and Kristine, with whom I shared nothing but great moments. To Irina and Patricia, I am specially thankful for honoring me with accepting the role of paranymphs. Thanks to the Argentine (and quasi Argentine) crew: Julieta, Agustin, Francesca, Ale and Lilia; and my MERIT and MGSoG friends and colleagues Jennifer, Giorgio, Josy, Samyukta, Omar, Sonila and Cheng. Also to my cohort friends with whom we shared a difficult but fun first year: Silja, Carlos, Guney, Manoj, Ozge, Sonja and Katie. Thanks to Marco for our squash games! Thanks also to my wonderful office mates: Oxana, Sachin, Flo, Ilire and Richard for keeping the office a thought-provoking and good snacking place. Thanks to the 
Iranian sweethearts Sepideh, Shuan and Iman. Thank you dearly, neighbor Shuan, for an almost life-saving strategic intervention one random day at 7 am. Special thanks to Eze for his unparalleled help and support during my first year. Thanks to Antje and Stuart for hosting me when I first arrived in Maastricht.

I already dedicated the dissertation to my partner and our baby Lara. On more impersonal terms, I would also like to dedicate the book to a very strange animal: all those men and women who insist on being part of the solution to something, when all the incentives are to become part of the problem. So what if they cannot be explained.

Luciana V. Cingolani Frankfurt, September 2014 


\section{Contents}

Introduction

Chapter 1: The State of State Capacity: a review of concepts, evidence and measures

Luciana Cingolani

Chapter 2: Minding Weber more than ever? The impacts of State Capacity and Bureaucratic Autonomy on development goals Luciana Cingolani, Kaj Thomsson and Denis de Crombrugghe

Chapter 3: Meddle or Tie your Hands? Bureaucratic technologies for Adaptability and Predictability in Argentina and Brazil Luciana Cingolani

Chapter 4: The Anti-corruption Office of Argentina: Momentous, idle... and momentous again? Luciana Cingolani

Value creation of the research

Abstract (in Dutch)

183

Short biography

185 


\section{Introduction}

$\mathrm{A}_{\text {a particular phenomenon is truly important for the development agenda }}^{\mathrm{N} \text { unorthodox but perhaps extremely time-efficient way to know whether }}$ these days, is to see whether Pope Francis I has already addressed it.

Apart from encouraging breast-feeding and questioning the situation of African migrants in Italy, this man acquainted with an unusually large number of world issues has also spared some time to highlight the importance of equal treatment by the civil service. As he refused to travel on Vatican documents and rather initiated some paperwork to renew his native passport, he publicly requested the national authorities not to enjoy any preferential treatment. Whether the Pope will now be patient enough to queue-up for every visa the Argentine passport requires, remains an open matter.

Papal considerations aside, the importance of the civil service in fostering citizen's well-being has been a long-standing component of the development discourse. The quality, impersonality and professionalism of civil servants in carrying out their policy duties is deemed key in achieving prosperity, as well as equality. The German sociologist Max Weber claimed that "precision, speed, unambiguity, knowledge of files, continuity, discretion, unity, strict subordination, reduction of friction and of material and personal costs" were set at their optimal levels in modern bureaucracies. None of Weber's ideas, however, stopped cartoonists from portraying bureaucracies as sluggish turtles, almost an oxymoron of development.

Although slow bureaucracies are indeed problematic for development, it is the slow institutionalization of civil services themselves that truly represents a bigger hurdle for progress. While the academic literature is rich in theoretical insights favoring professional and insulated civil services, a wealth of empirical evidence suggests that clientelism and low expertise continue to dominate policymaking in most economies. Moreover, it is argued here that the quality of the civil service is the most fundamental component of the now more fashionable concept of state capacity, which only recently started to be incorporated in economic studies as a critical variable determining growth and development paths. 
Yet, the interest in unraveling how different institutional aspects play a role in development is still in its infancy. In the study of national bureaucracies, it is surprising how little we know about the particularities of the political economy factors leading to (or hindering) professional civil services in the context of developing countries. It is also notable how far behind we are when it comes to the measurement and comparison of different aspects of bureaucracies and state capacities, and their adequate use for impact estimations and actionable policy proposals.

This dissertation has the objective to offer new analytical angles about some of these issues. It contributes in answering specific questions such as: which are the tangible effects of bureaucratic features in welfare outcomes? how can novel efficient measures of bureaucratic quality be constructed? how do transition countries achieve better bureaucratic standards? and what are the political economy aspects that can undermine otherwise promising governance processes?

The endeavor is largely inter-disciplinary. While its core objectives would typically fall within the agenda of development economics, it aims to include analytical categories and concepts from public administration studies, comparative politics and political sociology. The book undertakes the difficult task of linking explanatory variables that relate to micro-governance dimensions with macro-developmental outcomes. For this reason, the research encounters the need to include different methodologies and empirical strategies throughout its individual articles. In this respect, it resorts to econometric analyses when examining the impacts of state features on development outcomes, comparative-case analysis when analysing country-level bureaucratic processes, and in-depth case analysis when scrutinizing micro-historical processes that determine state performance in particular areas.

Chapter I is dedicated to delimiting the book's analytical scope by providing a critical assessment of the historical usage, applications and measurements of the state capacity concept, and the importance given to the bureaucracy as a specific sub-component. It shows the great versatility of this concept and the importance of "using with care", as although raw intuition has been the main conceptual compass behind it, a slightly deeper examination might reveal analytical tensions, disciplinary and ideological biases, concept overstretching and problems with convergent and discriminant validity.

The chapter departs from the classic political sociology works of the seventies and eighties of scholars such as Theda Skocpol (1979), Charles Tilly (1975, 1992) and Peter Evans (1989, 1995), all concerned with the mechanics by which state-led initiatives can make a difference in particular development paths both in Europe and emerging economies. It suggests that these authors 
offered an initially consistent theoretical framework for the analysis of state and bureaucratic capacity, while later literature on state capacity departed significantly.

The chapter follows by proposing a systematic and cross-disciplinary analysis of both causes and effects of state capacity, mainly by looking at comparative and rigorous empirical works presenting econometric evidence. It first evaluates the role of state capacity for economic outcomes such as growth, productivity and innovation (Evans 1995, Weiss 1998; Evans and Rauch 1999, Dincecco 2011, Hamm, King and Stuckler 2012, among others), and later its effects on other political outcomes such as conflict management and war onset (DeRouen and Sobek 2004, Fearon 2005, Sobek 2010, among others). While the first effort is dedicated to understanding the importance that development economics granted to state transformative capacity starting in the eighties, the second overviews a more recent strand in political science that relates state features to the dynamics of international relations. Later, the chapter comes full circle by looking at the determinants of state capacity: first its historical and economic ones (e.g. Centeno 2002, Cardenas 2010), and later its political and behavioral ones (e.g. Besley and Persson 2007, 2008, 2009). The latter strand includes political economy and game-theoretic works looking at the micro foundations of state capacity building.

Later on, it provides a wide and systematic overview of conceptualizations and measurements of state capacity, based on a bulk of literature starting in the seventies, and covering several disciplines. It shows a trend from unidimensional definitions towards multidimensional ones, suggesting that the selection of particular aspects of capacity is a more sensitive approach than opting for generic, 'catch all' categories. This is also at least preliminarily supported by latent variable analysis found in the literature.

The chapter finalizes by reflecting upon several methodological challenges the concept entails: lack of clear definitions; lack of consistency between definitions and measurements; fuzzy operationalizations; observability problems with outcome-based measurements; lack of clarification about potential contradictions between multiple institutional sources of state capacity; ideological biases, among others.

The lessons learned from Chapter I encourage us to follow certain standards when working with the state capacity concept: a) choose rather narrow definitions that correspond to a particular state capacity dimension; b) match this definition with suitable measurements that hold construct validity; c) preferably avoid the circularity threat presented by outcome measures; d) favor historical and cross-country comparability; e) whenever possible, distinguish between multiple institutional sources of state capacity; f) discuss upfront any 
potential ideological biases that may arise in the chosen conception of the state.

Chapter II goes a step further and contributes to the study of the role of state capacity and bureaucratic arrangements on specific development outcomes. Given the wide array of possible interpretations of state capacity as shown previously, this chapter starts by proposing a strategy to clarify the nature of the relationship between state capacity and the narrower notion of bureaucratic autonomy. The strategy chosen involves both a theoretical and an empirical assessment of the links, where findings show that this relationship is not linear or straightforward as intuition may suggest. More precisely, it is shown that in less developed institutional contexts such as fragile states or autocracies the association may be inverse, with more state capacity meaning less bureaucratic autonomy, whereas more consolidated democracies reveal a positive linear association. The chapter's proposed theoretical explanation behind this is that more fragile settings require a higher level of political centralization instead of higher delegation towards the permanent bureaucracy, a situation which might actually hinder internal order and control over the territory.

After arguing that state capacity and bureaucratic autonomy need to be differentiated, the chapter continues by measuring both concepts in order to estimate their respective effects on two Millenium Development Goals over a 20-year period (1990-2010): child mortality and tuberculosis prevalence levels. The reason why these two particular health outcomes are chosen is because they represent indisputable universal goals. In this sense, the assumption that governments have actively attempted to reduce them is credible, and therefore, assessing capacity becomes meaningful. For the case of state capacity, several measures are replicated from proposals coming from the literature, classified into different dimensions: legal, administrative, fiscal and coercive capacity, along with some generic indicators. For bureaucratic autonomy, on the other hand, the lack of feasible time-series indicators prompts us to propose a novel minimalist but efficient index. This index is a simple formula based on a solid database on agency independence made publicly available by its authors, and computed through a variable informative of the regularity or irregularity of independent governors' turnovers.

After controlling for a multiplicity of potential co-determinants of child mortality and tuberculosis prevalence, the findings show that while bureaucratic autonomy exhibits a persistent negative and significant impact under different specifications (meaning that lower levels of autonomy predict higher child mortality and tuberculosis), state capacity shows much more unstable results. Other infrastructural and socio-demographic factors also show the expected 
significance. The conclusions of chapter II corroborate the importance of professional bureaucracies in achieving development goals, even in cases where the mechanisms seem very indirect. The article therefore contributes to the literature on bureaucratic autonomy and agencies (e.g. Gilardi and Maggetti 2011, Hanretty and Koop 2009), as well as the very scarce literature linking specific governance aspects with desirable social outcomes in a rigorous cross-country and historical perspective (e.g. Henderson et al. 2007).

While chapter II discusses bureaucracies in a very general way and as determinants of development, chapter III is dedicated to opening up these "black boxes" through a comparative case analysis of Argentina and Brazil during an equivalent time period, 1990-2010. Just as in the previous chapter, the interaction between politics and autonomous bureaucracies lies at the center, only that now the two-country comparison allows an exhaustive exploration of this interaction and its determinants.

This chapter departs from the idea that administrative state capacity is something that requires a mixture of policy adaptability and policy predictability technologies within national bureaucracies. By making this statement, the article takes distance from conceptions of state capacity which lean towards one or the other (e. g. "transformative capacity" as adaptability, versus "legal capacity" as predictability) in favor of a more comprehensive approach. Nevertheless, having explored the great complexity of the state capacity concept, it is argued here that a virtuous balance between bureaucratic technologies for adaptability and predictability is not the sole component of capacity.

A novel, originally compiled database on bureaucratic appointments, organizational chart reforms, agencification patterns and civil servants' career paths in the two countries is exploited for the purpose of the chapter. Argentina and Brazil are chosen because they represent two transition economies sharing many similarities in their institutional profiles, but while Brazil has been deemed closer to the developmental state type, Argentina remains largely neopatrimonial. This work investigates whether some of these differences can be attributed to their respective bureaucracies.

The chapter proposes different strategies to assess adaptability and predictability technologies in both cases through the large amount of empirical data gathered. All in all, the results indicate that Argentina has built its adaptability capacities far more than its predictability ones, while Brazil displays a more balanced interaction. The risk for Argentina is to have an overall volatile and short-termist policymaking matrix, where the political sphere dominates and takes over the permanent bureaucracy.

The final section of the chapter is dedicated to unravelling the various political 
economy factors illuminating the contrast between the countries, including the role of Congress and government majorities, the public administration traditions, different state reform initiatives, and the diversification of the economic structure.

The chapter aims to represent a contribution to both the comparative-empirical assessment of civil services, as well as the understanding of the complexity behind administrative capacity building in transition economies. It therefore establishes a dialogue with three strands of literature described at the beginning of the article: works on principal-agents and bureaucratic politics (Geddes 1996, Huber and Lupia 2001, Alesina and Tabellini 2007), agencification theories and the regulatory state (Majone 1994, Gilardi 2008), and developmental research on "pockets of efficiency" within public bureaucracies (Hout 2007, Roll 2011).

Finally, chapter IV presents an in-depth case analysis of the Argentine Anticorruption Office, as a strategy to illustrate with great level of detail the mechanisms by which ruling coalitions can effectively constrain the work of otherwise independent organizations. The emphasis of previous chapters in quantifying state features with comparative purposes is now turned into a purely qualitative effort that prioritizes the understanding of how causal mechanisms operate between three concepts of interest throughout the thesis: institutions at the general country-level (such as parliamentary dynamics, the constitution and public service traditions), the levels of bureaucratic autonomy related to these, and the way in which autonomy affects organizational capacity building in the field of anti-corruption policies. The field of anticorruption is chosen because it is assumed that some degree of agency independence (formal or informal) is essential to achieve high agency performance, and therefore the interplay between politics and the bureaucracy can be properly observed. In addition, this particular agency is selected because of the variance it displays over time on several organizational aspects, which illustrate the critical role of civil services in securing certain outcomes within an important developmental area such as transparency.

The inclusion of chapter IV is intended to offer a methodologically-balanced view to the book: while the efforts to capture and quantify objective bureaucratic patterns of chapters II and III represent a contribution to the systematization of evidence around these issues, they are less informative of the sequencing or characteristics of causal mechanisms. Chapter IV aims to offer insights in these respects, which are also more relevant for any potential policy implications.

The chapter looks at the 'critical junctures' or key political decisions that set the agency on particular performance paths between its genesis in 1999 
and 2012. It also emphasizes the importance of looking beyond immediate agency performance and capturing more general levels of administrative capacity based on the structural features that remain stable throughout different political cycles. The findings show that agency autonomy, both de jure and de facto play a strong role in performance, and that although multiple political manoeuvres can hinder immediate performance, more structural agency capacity should be analyzed through a longer time perspective and the interaction of multiple dimensions.

The findings and approach contribute to a compact literature on anticorruption agencies, an area more dominated by practitioners than academics (e.g. Meagher 2005, De Sousa 2010). In particular, it helps bridge an enormous gap on Latin American anti-corruption agencies, an area that remains largely descriptive and dominated by legal studies.

The dissertation, therefore, goes from higher abstraction to more specific issues, in order to show not only some general patterns and associations critical to state capacity building, but also more tangible causal mechanisms that determine the fate of governance processes in settings where this is most needed.

The mission of unravelling how power relationships shape a country's development is often a long, complex, yet inescapable journey. The manner in which institutions, organizations, players and rules configure particular decisionmaking matrices can make an unimaginable difference in the results societies achieve when attempting to solve their collective problems.

The present compilation represents an effort to shed some light on potential strategies for state capacity building, considering its pivotal role for wellbeing and the complexity of its determinants. It mainly focuses on transition economies undergoing major reform processes and still in the search for institutional maturity.

The findings of the different chapters also encourage some further reflections regarding policy implications. Perhaps the most obvious one is that in the context of developing countries, the building of higher bureaucratic capacity may result in faster achievements in the socio-economic front. Although it is a well-known fact that building a proficient civil service is highly conducive to development, the results should also encourage experts to handle with greater sensitivity the relations between ruling elites and their autonomous bureaucracies. In other words, it is not only the building of the permanent civil service what is important, but the contribution to the effective separation between the political arena and the bureaucratic one, a separation that has not effectively taken place in many developing countries. 
Also, the research shows that unravelling the particular rules and arrangements that help create a stable and cooperative decision-making arena is an important goal. The detection of these institutions should be taken into consideration when planning comprehensive reforms in countries with a similar profile as the ones selected, and most likely before placing too much hope in policies alone.

Another finding concerns countries' organizational capacity in the anticorruption fight. The in-depth examination of the Argentine Anti-Corruption Office reveals that although the success of transparency initiatives depends greatly on political windows of opportunity and the original powers granted to the relevant stakeholders, the accumulation of expertise and capacity can still occur when the initial momentum is lost. It becomes important to distinguish the factors that negatively affect organizational capacity in a structural way, from those that are potentially easy to reverse. This Argentine agency suffered many subtle attacks, but still an important degree of capacity was built throughout the years. This finding offers an optimistic note regarding the role of anti-corruption agencies more generally, in a context where their effectiveness has been much debated.

To summarize, the book moves the current research frontier forward on several fronts. First, it makes a methodological effort to conciliate macrodevelopmental insights favoring country comparability and historical depth with micro political economy aspects regulating the interactions between key players in domestic policy-making. While the first set some important standards for empirical quantitative analysis, the second often enrich the understanding of causal mechanisms and help detect tradeoffs and tensions.

Additionally, the chapters put forth some novel ideas on how to operationalize and measure relevant bureaucratic aspects, in a way that captures essential details, and at the same time maintains a generality level that allows comparability and replication. The measurement of bureaucratic aspects is still perhaps one of the weakest areas in comparative politics.

Also, an original comparative database for Argentina and Brazil has been compiled gathering information on bureaucratic organizational charts, bureaucratic appointments, career paths and agencification trends for the period 1990-2010. This database is meant to be publicly available so that more analyses can be performed for the post-democratic era of both countries.

More generally, the book draws attention towards state structures and the civil service as fundamental but still marginally explored institutional aspects that affect welfare outcomes and prosperity paths. Our knowledge of domestic bureaucracies in developing contexts remains too low for its importance. 
Fortunately, promising avenues are opening up in the research agenda. More solid evidence, comparative quality and open access to data will contribute to facing this challenge. 


\section{References}

Alesina, A. and Tabellini, G. (2007). Bureaucrats or politicians? Part I: A single policy task. The American Economic Review, 97(1):169-179.

De Sousa, L. (2010). Anti-corruption agencies: between empowerment and irrelevance. Crime, law and social change, 53(1):5-22.

DeRouen, K. R. and Sobek, D. (2004). The dynamics of civil war duration and outcome. Journal of Peace Research, 41(3):303-320.

Dincecco, M. (2011). Political Transformations and Public Finances: Europe, 1650-1913. Cambridge University Press.

Evans, P. and Rauch, J. E. (1999). Bureaucracy and growth: A cross-national analysis of the effects of 'Weberian' state structures on economic growth. American Sociological Review, 64(5):748-765.

Evans, P. B. (1989). Predatory, developmental, and other apparatuses: A comparative political economy perspective on the third world state. Sociological Forum, 4(4):561-587.

Evans, P. B. (1995). Embedded Autonomy. Princeton University Press.

Fearon, J. D. (2005). Primary commodity exports and civil war. Journal of Conflict Resolution, 49(4):483-507.

Geddes, B. (1996). Politician's dilemma: building state capacity in Latin America. University of California Press.

Gilardi, F. (2008). Delegation in the regulatory state: independent regulatory agencies in Western Europe. Edward Elgar Publishing.

Gilardi, F. and Maggetti, M. (2011). The independence of regulatory authorities. In Levi-Faur, D., editor, Handbook on the Politics of Regulation. Edward Elgar Publishing.

Hamm, P., King, L. P., and Stuckler, D. (2012). Mass privatization, state capacity, and economic growth in post-communist countries. American Sociological Review, 77(2):295-324.

Hanretty, C. and Koop, C. (2009). Statutory interpretation, appointment method, and agency independence.

Henderson, J., Hulme, D., Jalilian, H., and Phillips, R. (2007). Bureaucratic effects: Weberian state agencies and poverty reduction. Sociology, 41(3):515532 . 
Hout, W. (2007). Development under patrimonial conditions: Suriname's state oil company as a development agent. Journal of Development Studies, 43(8):1331-1350.

Huber, J. D. and Lupia, A. (2001). Cabinet instability and delegation in parliamentary democracies. American Journal of Political Science, 45(1):18-32.

Majone, G. (1994). The rise of the regulatory state in europe. West European Politics, 17(3):77-101.

Meagher, P. (2005). Anti-corruption agencies: Rhetoric versus reality. The Journal of Policy Reform, 8(1):69-103.

Roll, M. (2011). The State that Works: Pockets of effectiveness as a perspective on stateness in developing countries. Technical report, Arbeitspapiere des Instituts fur Ethnologie und Afrikastudien der Johannes GutenbergUniversitat Mainz.

Skocpol, T. (1979). States and social revolutions: a comparative analysis of France, Russia, and China. Cambridge University Press.

Sobek, D. (2010). Masters of their domains: The role of state capacity in civil wars. Journal of Peace Research, 47(3):267 -271.

Tilly, C. (1975). The formation of national states in europe. Princeton: Princeton University.

Tilly, C. (1992). Coercion, capital, and European states, AD 990-1992. WileyBlackwell.

Weiss, L. (1998). The myth of the powerless state. Cornell University Press. 


\title{
Chapter 1
}

\section{The State of State Capacity: a review of concepts, evidence and measures}

\author{
Luciana Cingolani*
}

\begin{abstract}
What is state capacity and how does it affect development? The concept of state capacity acquired centrality during the late seventies and eighties, sponsored by a rather compact set of scholarly works. It later permeated through several disciplines and has now earned a place within the many governance dimensions affecting economic performance. The present article aims to provide a historical account of the evolution and usage of the state capacity concept, along with its various operationalizations. It examines in particular: a) the growing distance in the usage of the concept by different disciplinary and thematic fields; b) the process of 'branching out' of the concept from restricted to more multidimensional definitions; c) the problems with construct validity and concept stretching, and d) the generalized lack of clarity that exists regarding the institutional sources of state capacity.
\end{abstract}

\section{Introduction}

"The state has been brought back in. It now lumbers through the halls of academe, a great clumsy creature that no one quite knows what to do with." Barbara Geddes (1996) The Politician's Dilemma

The great clumsy creature portrayed by Geddes in her 1996 Politician's Dilemma

*Maastricht Graduate School of Governance - UNU-Merit. Email: cingolani@ merit.unu.edu. An earlier version of this article can be found as: Cingolani, Luciana (2013) "The State of State Capacity: a review of concepts, evidence and measures", UNU-Merit Working Paper 2013-053. United Nations University. 
continues to create puzzlement today. Although it is well acknowledged that state structures and behavior are critical to development, efforts in dissecting and scrutinizing this 'creature' have run short. In an article titled The Strange Absence of the State in Political Science, Fukuyama (2012) contends that while many scholars are keen to do research on power-checking institutions, very few pay attention to the way the state actually accumulates and exercises power through its executive branch and bureaucracy. Part of the explanation, he argues, is that the predatory reputation of states among political economy scholars has turned the attention towards power limitation (Fukuyama 2013), or perhaps simply that assessing checks is methodologically easier than assessing execution potential.

Although much has changed since Geddes' book was published, the versatility of the literature on state capacity is largely reflective of her initial statement. In its various forms, state capacity has been linked to different outcomes: growth and economic performance (Evans and Rauch 1999; Hamm and King 2010; Hamm, King and Stuckler 2012; Dincecco and Katz 2012; Dincecco and Prado 2012), industrialization (Evans 1995), innovation (Weiss 1998), levels of violence (Huntington 1968), prevention of civil wars and conflict (Fearon and Laitin 2003, Fearon 2005; DeRouen and Sobek 2004; DeRouen et. al. 2010), war contagion (Braithwaite 2010); the implementation of peace agreements (DeRouen et. al. 2010), among others. But while empirical works on the determinants and consequences of state capacity have flourished in particular in the recent years, questions about what state capacity truly is, how it should be captured, and other several methodological challenges associated with it are much less resolved.

This article has the objective of providing a comprehensive review of the state capacity literature throughout many years and disciplines. It seeks to better unravel how scholars have conceptualized and measured state capacity, as well as the existing evidence regarding both its determinants and its consequences for development. It hopes to offer a critical analysis of the strengths and weaknesses associated to the concept and a benchmark to disentangle better and worse operational alternatives.

The next section reviews some of the pioneering works, mostly from classic political sociology and economic history. The third section provides a comprehensive analysis of the existing evidence on causes and effects of state capacity, clustered according to the different topics at hand. Section 4 provides a systematic overview of the conceptualizations and measurements in the literature, looking at the many dimensions of capacity. The fifth section discusses some of the methodological and empirical challenges at stake. Section 6 outlines some of the lessons learned. 
Several conclusions arise from this examination. The first and most salient one is perhaps the difficulty of invoking state capacity as a generic concept. There are multiple aspects of capacity, suggesting that a naive understanding of it might overlook important tradeoffs and contradictions. Also, there are broad and narrow definitions, where the former often fail to distinguish themselves from other constructs such as rule of law, governance or quality of government. Issues of concept stretching and construct validity arise as the versatility of the concept increases. In spite of this, there is some convergence in the conceptualization of state capacity over time that looks promising. Finally, measuring state capacity represents the most important challenge for research, in particular for time series analysis and large $\mathrm{N}$ comparisons.

\section{The pioneering works on state capacity: political sociology and economic history}

The concept of state capacity is born out of the interest in understanding the role of the state in development, a highly positioned objective in the agenda of the political sociology of the second half of the twentieth century. Before that, the state as a primary object of study was subject to oblivion. According to Jessop (2001) the state's relevance was reinstated in two waves of political sociology scholarship: in the sixties, through the neo-Marxist theories on the capitalist state, and in the late seventies and eighties through the 'statist' institutional movement. In these works, discussions about state formation and state autonomy act as precursors of more systematic conceptualizations of state capacity.

The first wave took place in Europe, and was motivated by the need to reassess the traditional Marxist view of the state, against the backdrop of an emerging welfare economy. While traditional Marxism takes on an instrumentalist view of the state by which elites make use of it to fully regulate and reproduce the capitalist system to their benefit, there are now renewed concerns regarding state autonomy. The redistributive effects of welfare policies start to suggest that the state apparatus is endowed with 'relative autonomy' from the dominant class (Poulantzas 1974; Miliband 1969, Offe 1972) ${ }^{1}$. In spite of internal disagreements, this neo-Marxist literature agrees that the state acts as a stabilizer of capital-labor relations, helping the elite conceal potential contradictions within the system.

The second wave takes place in the U.S., and adopts a perspective that deviates

\footnotetext{
${ }^{1}$ The argument is that the state needs this relative autonomy in order to truly fulfill the interests of the entire dominant class (Skocpol 1979: 27).
} 
both from previous Marxist and behavioralist approaches in the study of governmental action. It represents a change of paradigm from society-centrism towards state-centrism, and the possibility of autonomic action within the state. It is strongly rooted in the Weberian tradition of modern states (e.g. Weber 1978), where two salient characteristics acquire centrality: the importance of coercive power monopolization by the central administration and the formation of professional, permanent and insulated civil service cadres. The reminder of this section focuses on the 'statist' movement and its derivations.

One salient early work within this scholarship is the highly detailed historical account of Charles Tilly The Formation of National States in Western Europe (1975), a collection of essays that looks into the role of war in the formation of national states in Western Europe ${ }^{2}$. The pivotal objective of the book is to show that variations in state formation processes respond to different countries' military needs for warmaking (mainly in France, England and Germany), by means of securing an efficient and centralized revenue extracting apparatus. These efforts are complemented and extended in Coercion, Capital and European States, AD 990-1992 (1992). In Tilly's work, stateness in Western Europe is defined by formal autonomy, differentiation from nongovernmental organizations, centralization and internal coordination (1975: 35). The level of stateness is in turn determined by the state's capacity to raise tax, that is, the capacity to "build an apparatus which effectively drew the necessary resources from the local population and checked the population's efforts to resist the extraction of resources" (1975: 40). ${ }^{3}$ The importance of conflict and revenue extraction in determining state features initiated a long-lived stream of research more recently reappraised by political economy and conflict studies.

\footnotetext{
${ }^{2}$ Previous classic contributions to the study of state formation in Western Europe include The Civilizing Process. Vol II State Formation and Civilization by Norbert Elias (1982, first edition 1939) and The Social Origins of Democracy and Dictatorship by Barrington Moore (1966). The first provides a detailed account of the long historical evolution in Western Europe from a fragmented network of feuds into centralized absolutist regimes successfully claiming the monopoly of coercive power. The volume narrates the interactive and reinforcing nature of changes in microsocial behavior and culture, and more structural and permanent political transformations. The second resorts to a comparative historical analysis in order to show how endowments and productive structures determine the shaping of different political regimes in modern economies such as the U.S., Germany and France.

${ }^{3}$ The work of Tilly is vast, so his conceptualization of state capacity evolved likewise. In the book Democracy (2007), where he studies the interaction between democracy and state capacity, the latter is defined in a broader way as "the extent to which interventions of state agents in existing non-state resources, activities and interpersonal connections alter existing distributions of those resources, activities and interpersonal connections as well as relations among those distributions" (: 16).
} 
Another prominent early work on the state comes from the classic by Theda Skocpol (1979) States and Social Revolutions: a comparative analysis of France, Russia and China, a book that revives debates about the linkage between state autonomy and development. It analyzes how the state plays a role in the outbreak of revolutions in the three countries, by comparatively and historically assessing the interactions between the state apparatus and the ruling elites, and between bureaucratic actors themselves. The nature of these interactions determines the state's autonomic power. Although Skocpol focuses on the administrative capacity to carry out central policies, she acknowledges other dimensions too, such as coercive and extractive capacity: "Obviously, sheer sovereign integrity and the stable administrative-military control of a given territory are preconditions for any state's ability to implement policies. Beyond this, loyal and skilled officials and plentiful financial resources are basic to state effectiveness in attaining all sorts of goals." (Skocpol 1979: 16). The work shows that state structures affect the nature of revolutions, and these, in turn, shape historical processes of state formation: "strengthened states -more centralized, bureaucratic and autonomously powerful- emerged from all three Revolutions" (: 285). Her work is ground-breaking in the study of revolutions, since it escapes a purposive perspective and looks at deeply rooted structural factors.

A more micro-political approach to state capacity is taken in Skocpol and Finegold (1982), where two U. S. governmental programs of the post-depression in the 30 s are examined in detail: the National Industrial Recovery Act (NIRA) and the Agricultural Adjustment Act. The administration of these two take opposing trajectories: while the first soon collapses under conflict and confusion, the second endures and becomes institutionalized. The explanation of the differences is centered around bureaucratic capacity: while the Agricultural Adjustment Act could rely on a capable administrative leadership, organizational unity and successful political learning, the NIRA run short of all of these.

A similar perspective is presented in Bringing the state back in by Evans, Rueschemayer and Skocpol (1985). This compilation of articles is fully centered around the purpose of showing the mechanisms by which the autonomous power of the state operates. In the introduction, Skocpol (1985) defines state capacity as whether a state is able to "implement official goals, especially over the actual or potential opposition of powerful social groups or in the face of recalcitrant socioeconomic circumstances" (: 9). Autonomy, on the other hand, is present when: "[state] organizations claiming control over territories and people may formulate and pursue goals that are not simply reflective of the demands or interests of social groups, classes or society" (: 9). Although the authors recognize that the state is not a single, monolithic unit, they also 
argue that it is neither a simple arena for resource allocation, as it is portrayed in the pluralist scholarship. They call for an inductive approach to the study of the state, as they contend is the best way to capture the complexity of state-society relations. In this book, Rueschemeyer and Evans (1985) place the effectiveness of state intervention in the economy at the center of the scene. From a Weberian approach, they contend that a balanced combination of professional cadres in the bureaucracy and proper levels of intra-state agency coordination are the key to economic transformative capacity, an idea that would be more extensively explored in Evans (1995).

At the core of the Weberian tradition also lay the debates on the neopatrimonial state, albeit not always placing state capacity at the center. The meaning of neopatrimonialism is highly contested and controversial ${ }^{4}$, but is generally understood as a political setting in which-following Weber's typologies-, principles of both rational-legal and patrimonial state administrations coexist in a complex manner. The concept is often closely related and intertwined with patron-client networks, patronage and the notion of 'rentier state' in political economy studies ${ }^{5}$. Although formal rules have been put in place in neopatrimonial states, informality permeates the system and strong patrons strategically centralize and allocate political and economic resources to maximize private gains and maintain their privileged positions at the same time. In public administration studies, a particular strand has given special attention to the existence of so called "pockets of efficiency" (also "pockets of effectiveness") in national bureaucracies (Evans 1989), administrative strongholds where bureaucratic action is successfully isolated from electoral or patronage politics and reproduces itself over time on the basis of rational-legal rule (see for example Hout 2007, Roll 2011).

Other scholarly endeavors have contributed to the systematization of the state capacities literature. Nordlinger (1982) shows that public officials have the power to define public policy autonomously within democratic contexts. Skowronek (1982) explores how the fragmented and localistic state capacities of the United States in the 19th century shaped the industrialization process. Wildavsky (1986) analyzes the inertial evolution of the public sector. According to Krasner (1984), most of these statist approaches are persuasive in the idea that state structures can constitute valid explanatory variables for development outcomes.

\footnotetext{
${ }^{4} \mathrm{~A}$ critical and systematic discussion on the concept of neopatrimonialism and its derivations can be found in Erdmann and Engel (2007) and for Africa in particular in Bach (2011).

${ }^{5}$ Rentier states are defined as those that rely fiscally on the rents derived from the export of natural local resources (Chaudhry 1989, Karl 1997; Ross 1999, Kohli 2004). Some of this literature is later referenced in conflict studies.
} 
Beyond the most well-known state-centered perspectives on state capacity, other classic works have persuasively framed discussions in terms of the implementation power of the state. In particular, Joel Migdal and Michael Mann present a relational approach on the mechanisms of power execution, by which the interactive and mutually reinforcing exchanges between state and society shape the historical processes of state capacity building.

The books by Migdal, Strong States, Weak Societies (1988) is illuminating in terms of how state capacities are configured in developing countries. In contrast to the statist view, Migdal's sociocentric perspective sees the development of the state apparatus as determined by the type of the social structures it seeks to regulate. He contends that the state-centric perspective is not instructive in developing countries, as the core issue of state autonomy and strength cannot be presupposed. Migdal simply defines state capacity as "the abilities of state leaders to use the agencies of the state to get the people in the society to do what they want them to do" (1988: prologue), or otherwise to "achieve the kinds of changes in society that their leaders sought through state planning, policies and actions." (: 4). In this context, his perspective prioritizes the capacities to extract resources, regulate social relationships and penetrate the territory. He resorts to the dichotomous typology of weak and strong states, the former having high capabilities to complete these tasks, the latter unable to perform them ${ }^{6}$. The main question at stake in the book is why some countries were able to establish effective behavioral rules for societies, while others failed. Methodologically, the work takes on a qualitativecomparative approach to examine the cases of Egypt, India, Israel, Mexico and Sierra Leone through a most-different cases research design. He finds that the key to explaining state capacities is the distribution of social control among many organizations, including the state. In order to build a strong state (for example Israel), it is needed that colonial powers centralize social control and resources within a governmental organization instead of diffusing control through local chiefs. The latter option favors strong societies and weak states, and facilitates state capture. While strong societies are conducive to democracy, they hinder 'stateness', and therefore, the formation of a strong states.

In The sources of social power (1986 and 1993), Michael Mann introduces some innovative concepts in the field of state capacities. He studies power relations in terms of multiple and intersecting networks of influence, which represent organizational means of obtaining human goals. He defines four

\footnotetext{
${ }^{6}$ A similar typology depicting "soft states" was previously introduced by Gunnar Myrdal (1968). The weak-strong classification has been largely criticized for being inaccurate and too simplistic (e. g. Evans and Rauch 1999), but its general terms still persist in the states capacity literature (e.g. Fukuyama 2004, Acemoglu 2005).
} 
so-called sources of social power: ideological, economic, military and political, the latter being the state's domain. He contends, in turn, that states exert two types of power: despotic and infrastructural. Despotic power is the state's power to impose mandates over society, or "the range of actions the state elite is empowered to undertake without routine negotiation with civil society groups" (Mann, 1988: 59), while infrastructural power refers to "the institutional capacity of a central state, despotic or not, to penetrate its territories and logistically implement decisions" (: 59). The distinction introduced by Mann generated new debates, as despotic power was until then the most frequent interpretation of state power ${ }^{7}$.

Relational approaches to state capacity gained important terrain in moving beyond organizational views of the state, which in turn fostered theoretical discussions about governance as a broader concept than government (see, for example, Robinson 2008 as an example of state capacity analyzed in terms of socio-economic engagement).

\section{Determinants and effects of state capacity: de- bates and evidence}

Following the classic literature on state capacity of the eighties, a large stream of works have flourished regarding both the effects as well as the determinants of state capacity. On occasions these works follow the interests and theoretical insights of the early literature, and on others the conceptualizations are somewhat weaker, based on a more intuitive understanding of state capacity.

In general, the interest in state capacity was channeled through four distinct -yet interlinked- thematic/disciplinary fields: development economics and economic history, comparative politics, conflict studies and game-theoretic political economy. At the risk of oversimplifying, it can be said that debates on state capacity, growth and industrialization are examples of the first; the role of state strength in conflict onset is an example of the second; the interest in the effects of micro and macro political factors on state professionalization is an example of the third; and the study of the incentives for actors to invest in state capacity is an example of the last disciplinary field (the last two have tended to converge progressively). The present section examines some of these works and their evidence. It starts by exploring the effects of state capacity on economic outcomes, followed by its effects on conflict and political outcomes.

\footnotetext{
${ }^{7}$ Soifer (2008) makes a detailed account of the ramifications of the different interpretations of infrastructural power in the literature.
} 
It later moves on to assess the literature on the historical and economic determinants of state capacity, and finishes with a review of its political and institutional determinants.

\subsection{How state capacity affects development outcomes}

\subsubsection{Bureaucratic capacity, Innovation and Industrialization}

In Embedded Autonomy (1995) Peter Evans analyzes the ways in which state behavior has the power to shape structural change and promote industrial growth through its transformative capacity. He focuses on the information technology (IT) sector of newly-industrializing countries (NICs) such as Brazil, India, and South Korea during the seventies and eighties. The main question explored is how can the state play an active role in helping modern economies fit the global division of labor. He posits that the range of actions a government can take depends on the kinds of state structures in place. More precisely, the secret to a developmental state is the existence of high levels of embedded autonomy, a combination of internal bureaucratic coherence within agencies and external connectedness with key industrial sectors. The case of Korea is the one that fits more closely the ideal of embedded autonomy, while Brazil and India represent cases of partial success. In predatory states -exemplified by the case of Zaire-, civil servants pursue their own goals, overall individual maximization predominates over collective goals, and frail bureaucracies fail to create a virtuous association with key industrial sectors ${ }^{8}$. Embedded Autonomy manages to enrich discussions on how exactly states intervene in the economy, by bringing forward another typology of state behavior. According to it, states can take on four main roles: a policing role of 'custodian' or general regulator; a 'demiurge' role of providing goods and services, a 'midwifery' role of attracting capital to new sectors; and a 'husbandry' role of nurturing and developing these sectors. Developmental outcomes depend on how these roles are combined. For the IT industry in particular, the book illustrates that a proper combination of midwifery and husbandry steering tends to be more successful than any of the other two ideal types.

Linda Weiss (1998) follows the path of Evans (1995) by exploring the transformative capacity of states against the backdrop of globalization, and challenging mainstream views about the demise of the state in this new type of world (e.g. Strange 1996). Similarly, she contends that the level of state intervention is

\footnotetext{
${ }^{8}$ The typology that depicts states as predatory, intermediate or developmental is extensively explored in a previous work (Evans 1989), where Evans argues largely against the Neo-utilitarian perspective conceiving the state as inherently antidevelopmental.
} 
not informative of its power, but transformative capacity is. The latter is conceived as "the ability [of the state] to coordinate industrial change to meet the changing context of international competition" (: 7). As a step further from Evans, Weiss studies the somewhat contradictory relationship between transformative and distributive capacity through five case studies: Taiwan, Japan, South Korea, Sweden, and Germany. In her cases, transformative capacity dominates the emerging economies of Taiwan and South Korea, whereas distributive capacity remains at the core of the Swedish economy. Germany and Japan, on the other hand, are two cases with a proper combination of both capacities. She finds that while distributive capacity grants high density to state-society relations, it hinders innovation within the industrial sector.

\subsubsection{State capacity and growth}

Following the line of state capacity as bureaucratic professionalization, Evans and Rauch (1999) and Rauch and Evans (2000) represent seminal empirical assessments of the impact of bureaucratic 'Weberianness' on economic growth. They design and construct the Weberian State Dataset, a dataset made of surveys examining bureaucratic features such as meritocratic recruitment, salary arrangements and career paths in 35 developing (semi-industrialized) countries for the period 1970-1990 (time-invariant). The surveys required the assessment of either 2 or 3 experts in each country, who answered questions about objective aspects of the different bureaucratic features. Making use of this novel source of data, they present evidence showing strong associations between 'Weberianness' and economic growth in these emerging economies (Evans and Rauch 1999). Also, Rauch and Evans (2000) find significant associations between levels of bureaucratic 'Weberianness' taken from their survey and notions of state effectiveness, as measured in other sources of data.

Bockstette, Chanda and Putterman (2002) develop an index of state antiquity for a large set of countries that they later associate positively with GDP per capita levels and economic growth, among other things. The article shows and reinforces the idea that early state formation and institution building is an advantage in achieving higher performance for development.

The work by Hamm and King (2010) concentrates on the role of state capacity as a mediating variable between growth and development. They seek to complement debates on the effects of Foreign Direct Investment (FDI) on national economies, where existing evidence has been ambiguous. In this article, they aim at providing an empirical analysis assessing the comparative impacts of FDI and domestic investment in post-soviet transition countries over time, mediated by institutional aspects. They assess the link between 
FDI and growth in a panel of 31 post-soviet transition economies between 1989 and 2004 through a series of fixed effect regressions, and instrument FDI with foreign aid measures in order to minimize endogeneity. Given the lack of relevant data for these countries, state capacity is operationalized through national murder rates, as they argue is a good proxy for the governments' ability to provide stability and good enforcement, following Popov (2001). They find that FDI levels have a positive effect on GDP per capita only contingent upon high levels of state capacity, and moreover, that whenever a well-functioning state is not in place, FDI impacts can be negative. On the contrary, there is no evidence of the same positive effects on growth of domestic investment. They suggest these different impacts occur through several channels: a) the lack of predictable legal systems; b) the state's incapability to regulate capital to enhance national welfare; c) the incapability to protect and enforce property rights, which encourages short-term investments and fast capital repatriation; and d) the lack of a strong bureaucracy, which creates a fertile ground for extended corruption.

Hamm, King and Stuckler (2012) further develop the causal mechanisms by which FDI affects differently transition countries in the post-Soviet era. They challenge traditional market-centered explanations by proposing a neo-Weberian explanation for the variance in outcomes, one that focuses on the bureaucratic capacity of the state. State capacity is understood as the existence of infrastructural power (Mann 1986): the ability of the state to penetrate society and realize its objectives. They pursue two empirical strategies in order to show that reform initiatives such as mass privatization impacted negatively on state capacity and growth. The first one is a time-series analysis for 25 post-communist countries between 1990 and 2000, exploring the effect of mass privatization on two response variables: GDP per capita and state capacity. State capacity is measured here through an objective indicator of fiscal capacity: changes in total government spending between 1992 and 2000 (government spending in $2000 \mathrm{U}$. S. dollars expressed as the share of 1992 spending). Mass privatization is captured through a novel indicator taken from the European Bank for Reconstruction and Development Transition Report Series. The second empirical strategy is a cross-sectional analysis of the impacts of mass privatization and price liberalization on state capacity through logistic regressions. In this case, state capacity is measured through three subjective indicators from BEEPS firm-level surveys from 3550 firms across 24 countries (World Bank/EBRD Business Environment and Enterprise Performance Surveys), as well as total government spending. The survey coded firm managers' answers on whether they thought the state was efficient, whether it respected property rights and whether higher corruption existed. The resulting evidence from both strategies shows that mass privatization programs hindered state 
capacity, and the latter affected growth negatively. The authors argue that shock therapy instrumented through privatization, price liberalization, fiscal and monetary austerity and free trade lowered fiscal capacity in countries where it occurred faster, and subsequently decelerated growth. Mass privatization affected state capacity directly by eliminating profits coming from state owned enterprises, which augmented budget deficits; and indirectly by creating agency problems due to the increasing dispersion of firm ownership, which fostered overall non-compliance by enterprises. Also, mass privatized firms were less likely to be endowed with strategic expertise and resources, and therefore failed to undertake successful restructuring programs. As a consequence of several factors, these firms preferred entering the black market (nonmarket activities), and therefore paid less tax to the state, reinforcing the vicious circle.

The articles by Dincecco and Katz (2012) and Dincecco and Prado (2012) explore the impacts of state capacity on long-run economic performance in Europe. Following the line of Dincecco (2011), they consider that state capacity is a combination of tax extraction centralization and executive power limitation through institutional checks. After arguing that different institutional reforms represented exogenous shocks to these two (uniform tax systems were implemented after foreign conquest, power limitation reforms occurred in a series of historical junctures), they analyze their impacts on a series of economic outcome measures.

Dincecco and Katz (2012) present two sets of simultaneous equation models where state capacity is proxied through levels of tax extraction and productive expenditure. A full-period model accounts for the endogeneity between performance (measured in GDP per capita in 1990) and government revenue (1650-1913). A second partial sample includes government spending as a measure of state capacity in addition to revenue (1816-1913). Both models include regime type dummies (centralized-limited, fragmented, centralized absolutist), arguing that these are exogenous. In their conclusions, they suggest that the causal direction is such that regime type affects tax revenue extraction and spending quality in the first place, and through this channel is then performance affected (: 18).

Dincecco and Prado (2012) present an empirical strategy that uses exogenous variation in fiscal capacity in order to assess its effects on productivity. Their measure of performance is the log of GDP per worker, and their measure of fiscal capacity is the share of total tax revenues from direct taxes (income, social security, payroll, property taxes). In order to find exgenous variance, they instrument fiscal capacity with war casualties, and construct three instruments: total casualties on major external conflicts between 1816 and 1913 another 
between 1700 and 1788 from Clodfelter (2002) and a third with casualties on major external conflicts between 1816 and 1913 from Correlates of War. They argue that through war, states made fiscal innovations that persisted in time and can explain performance. Additionally, they use the ratio of total tax revenue to GDP. After two-stage least squares estimations are run, the evidence suggests strong positive effects of state capacity on productivity.

\subsubsection{State capacity, Conflict and Fragile States}

After numerous incidents of state collapse at the beginning of the 21st century, the conflict literature in international relations started to take a special interest in state strength and capacity as potentially powerful explanatory variables behind the breakout of violence, in particular in Sub-Saharan countries. Several works account for this.

Fearon and Laitin (2003) show that among the factors that facilitate guerrilla warfare and insurgency are low financial, organizational, and political state capacities. Somewhat later, Fearon (2005) responds to Collier and Hoeffler's argument (2004) that the share of primary commodity exports is a determinant of civil war, by showing that this mechanism runs only through low state capacity. DeRouen and Sobek (2004) take a similar perspective. They find that state capacity is at the core of civil war outcomes and duration. They argue, however, that while a more effective bureaucracy favors the government, higher coercive power from the state does not necessarily have the same effect.

The relationship between conflict and state capacity is further and extensively explored in a special issue by the Journal of Peace Research. There, Sobek (2010) shows that more capable states provide lesser opportunities for rebels to initiate violence, as they are able to channel social demands in a way that limits the possibilities of rebels to achieve collective action. In the event of violence, capable states are more prone to choose bargaining as a way out. Braithwaite (2010) contends that state capacity affects the probabilities of contagion from neighboring countries. Lower state capacity gives a lesser chance to resist the spread of regional conflict, as exemplified in the case of the collapse of Zaire after massive influx of refugees during the 1994 Rwandan genocide. Using a simultaneous equation framework, Thies (2010), in contrast, finds no direct effect from state capacity on conflict onset, but an inverse relationship. DeRouen et. al. (2010), in turn, examine the importance of state capacity in the implementation of 14 peace agreements in Northern Island, Indonesia, Burundi, Mali and Somalia. Interestingly, state capacity is here "the states' ability to accomplish those goals it pursues, possibly in the face of resistance 
by actors within the state" (: 335). The authors find that state capacity is indeed an important determinant of both the enactment and implementation of peace agreements, and that the interaction between capacity and third-party intervention is more significant in low capacity countries.

McBride, Milante and Skaperdas (2011) present a dynamic game-theory approach to analyze the role of state capacity as a commitment-enabling institution in conflict resolution. Given a certain conflict, they analyze how different levels of state capacity affect the likelihood for peace to prevail versus the continuation of conflict. State capacity is understood as the quality of institutions that allow commitment enforcement, by protecting a portion of the disputed rents from being captured by war. In this model, each party needs to decide how much to spend in arming, given the expected payoff from winning the disputed rent, versus the protection of rents determined by the level of state capacity. Given these levels of arming and state capacity, each party determines whether to accept peace or not. The article proposes two versions of the model, one with exogenous state capacity and the other endogenizing this capacity, subject to three determinants: the type of intervention exerted by external forces; the history of interactions between the parties; and the past investments made in state capacities by adversaries. The main question at stake is: under what conditions will the parties invest in state capacity in order to reach the needed threshold for peace to be self-enforcing? The derivations of the model show that only when state capacity is sufficiently large peace is self-reinforcing.

\subsection{Determinants of state capacity}

\subsubsection{State formation and the historical determinants of state ca- pacity}

The so called 'bellicist' hypothesis of Charles Tilly (1975 1992) fostered many works on the historical determinants of state capacity, in particular regarding the impact of war in state formation.

The book by Centeno (2002), for example, seeks to unravel the impact of internal and external war in state effectiveness in Latin America. In contrast to the European case, organized violence in the form of state war in this continent is a rare occurrence, while state capacity is infrastructurally weak, presenting an interesting case of analysis in the light of the bellicist approach to statebuilding. In this framework, state capacity is understood as "the ability of the relevant political authority to enforce its wishes and implement policies" (: 3 ). The book first analyzes why violence is a rare occurrence, and then why 
the lack of violence and low state capacity reinforce each other over time. To answer the first, Centeno points at different factors: a) the fact that Latin America fought 'limited wars' instead of mass wars; b) it minimized border conflict by accepting colonially imposed borders; c) external powers mediated in wars; d) domestic elites were more divided than in Europe; e) more caste divisions existed, f) administrative chaos followed decolonization (: 22-23). After these initial conditions in which Latin America went through independence from colonial rule, a path-dependent story followed, where the lack of centralized violence led to weak statebuilding. The bellicist theory suggests several channels through which wars build states: by centralizing power and revenue extraction, by creating a higher level of national belonging that fosters more cooperation from society towards the state; through war success as a way to grant state legitimacy; through mass conscription, which improves organizational capacity and further centralization. Centeno explains why in Latin America these channels are broken. While administrative capacity barely existed at the moment of independence, partial wars did not encourage mass mobilization of armies, therefore discouraging its professionalization. Also, social divisions were above national sentiment and the results of war were mostly negative: debt, breakdown and chaos. Yet, within this universe he finds variations in the continent: the centralizing power of war was stronger in Chile, Mexico and Argentina. In the conclusions, Centeno suggests thinking about treating Europe as an exception instead of a rule. Thies (2005) further explores the relationship between wars and statebuilding in Latin America by empirically testing Centeno's theory. He finds that indeed in Latin America the occurrence of external war does not have a positive impact on taxation, while civil war has a strong negative one.

Cardenas (2010) offers further theoretical insights regarding the determinants of state capacity building in Latin America. In line with Centeno (2002) he argues that the Latin American state has been "extremely weak in terms of the most basic capacity measures" (: 2). Although initially capacity is understood as the "professionalization of the state bureaucracy, its ability to protect property rights and make credible commitments to private investors, as well as its ability to raise revenue from the society" (: 2), later fiscal capacity takes the main role: "state capacity is defined as the state's ability to generate tax revenue from the public" (: 15). The article presents a game-theoretic framework based on Cardenas and Tuzemen (2010 2011) that models the impact of four factors in state building: two traditional ones in bellicist accounts like internal and external war, and two novel ones, political and economic inequality. Capacity accumulation is modeled as investments under uncertainty, in the same vain of Besley and Persson (various). In a nutshell, whoever is in power (the citizens or the elite) has to make decisions on how much to invest 
in state capacity for the future, how much to tax, and the amount dedicated to providing public goods. Investments in state capacity are risky because they take away resources from private consumption, and can be used by the opposition at a later point in time for redistribution. There is uncertainty on how much society will value public goods in the second period, because it is determined by exogenous factors (e. g. internal or external wars). Each sector derives utility depending on the value of public goods and the resources left for private consumption after tax. The government makes the three decisions based on the maximization of the sum of weighted utilities of the two groups (the weight depends on whether the government is utilitarian or group-biased) plus the expected payoff for the second period, for the group who is in power in the first period. The decision on how much to invest in state capacity for period 2 depends on two unknown variables: the future value of public goods, and who will hold power, in addition to the expected net payoff. The result is that the optimal level of investment depends on the value for public goods in both periods, as well as the level of group-bias (the weight given to the value of private consumption for the ruling group). While conflict affects the first, political and economic inequality affect the second. The results show that political and economic inequalities lower the incentives to invest in state capacity. These deductions are contrasted empirically as well. The article resorts to a cross-sectional empirical strategy with 125 countries in order to see how each of the four variables is associated to state capacity. In line with Hendrix (2010) Cardenas retains only administrative and fiscal capacity ${ }^{9}$. The overall results suggest a strong positive association between the eight state capacity measures and political equality and external war; and a negative and significant association with internal conflict. The results for economic equality are more ambiguous. The role of external wars loses some significance when the estimations are run comprising only the last 50 years, therefore challenging somewhat the bellicist argument: while is seems true that intrastate conflict has hindered capacity in Latin America, external conflict does not explain capacity improvements in the region. Cardenas argues that this hypothesis might hold for the US. and Europe, but not other regions, and not for the last 50 years in a cross section of countries.

Cardenas, Eslava and Ramirez (2011) aim to test the hypotheses that external conflict has a positive impact on state capacity and internal conflict has a negative one with time-series data. They run GMM estimations on two panels:

\footnotetext{
${ }^{9}$ There are in total eight measures of state capacity, the first three fiscal, the last five administrative): i) GDP share of total revenue, ii) GDP share of income tax revenues, and iii) total tax share of domestic tax revenue; iv) outright confiscation and forced nationalization; v) ease of doing business; vi) government effectiveness; vii) question 21 from the State Capacity Survey from Columbia University; vii) state capacity measures from IADB.
} 
one covering 188 countries between (1975-2004) and another covering Colombian municipalities, accounting for conflict intensity and conflict type, and using mainly fiscal and legal capacity measures. They find that internal conflict has a negative impact on fiscal capacity and public goods provision, while the intensity of the conflict exerts the expected effect. There is no evidence that external conflicts, on the other hand, have a significant impact.

The work of Dincecco $(2009,2010,2011)$ has extensively studied the historical determinants of fiscal capacity in Europe, in a different vain of war-centered explanations. Dincecco (2009) analyses the mechanisms by which fiscal centralization and limited government reduce sovereign credit risk. Dincecco (2010) argues that the mechanism through which regime type reduces sovereign credit risk is a reduction of budget deficit. Dincecco (2011) explores the historical determinants of fiscal capacity in Europe between 1650 and 1913. The book assumes that states are predatory and that parliaments and institutions help set limits to expropriation. The main hypothesis is that the secret of wealthy countries is to have evolved towards building centralized powerful extractive systems, while developing institutions to control the expenses of the executive power at the same time. He shows and explains that throughout the period there is a passage from weak monarchic control over tax collection and strong control over expenditures towards strong extraction control and limits to spending, and explains how this passage happens. The book also examines empirically through panel estimations and structural breaks models the effects of institutional changes on government revenue and fiscal prudence, showing that both contribute to better fiscal standards.

Charron, Dahlstrom, Lapuente (2012) offer yet another perspective on how state formation affects subsequent types of administrative infrastructure. They observe from the scholarly work on state formation in Europe between the 16th and 18th centuries that different historical processes derived in either patrimonial or bureaucratic state infrastructures, in the terms of Ertman's typology (1997). Patrimonial administrations were directly accountable to the leader (as is the case of France, Spain, Portugal, Poland and Hungary), while bureaucratic ones extended the base of meritocratic appointments (Germany, Britain, Denmark). They argue that the type of functioning state originally instated creates a path dependency that will affect other institutions, and will also shape the effect that any legal framework will have. They do not contradict the legal origins theory of La Porta et al. (1999), but argue that the ultimate cause of institutional quality is the type of administration built. In their opinion, the selection of legal tradition between Common Law and Civil Law, is not entirely exogenous, as it is a voluntary decision that depends on the existing state, and it is therefore politically-motivated. As an example they mention that Latin American states were formed after the legal tradition 
was established in the conquest. Through OLS regressions, the article compares the importance of state infrastructure versus legal origin in explaining 16 institutional indicators grouped in four areas: 1) government regulation; 2) judicial institutions; 3) financial institutions and 4) governance in 31 OECD countries. The findings show positive and significant associations in 11 of the 16 dependent variables when all countries are in the same sample. They also run separate t-tests to assess the statistical significance of the difference in the institutional indicators between groups of legal origin and find mixed evidence.

\subsubsection{Investments in state capacity}

There is a fast growing strand of game-theoretic literature looking at the incentives to invest in state capacity, which partially overlaps with the economic history works on state formation (e.g. Cardenas 2010). Much of this strand is embedded in the 'limited state' literature, were the subject of state capacity is indirectly addressed by the interaction between institutions and property rights enforcement (North 1981 1990). In general, it is assumed that contracting institutions are essential in order to provide the adequate environment for investment and innovation. The enforcement of property rights requires a strong legal system that constrains the ruling elite's expropriation potential, through predictability and rule of law. In this respect, state capacity is understood mainly as legal capacity, and it is associated with less intervention potential.

While Acemoglu and Verdier (1998) and Acemoglu (2005) gauge the effect of enforcement capacity and state strength in the economy, the subsequent works look deeper into how state capacity is built, and what are the incentives actors face in order to invest in it.

Acemoglu and Verdier (1998) study the relationship between investments, bureaucratic corruption and the enforcement of contracts. In contrast to other works within this literature, both the enforcement of property rights and bureaucratic corruption are now endogenized. In this framework, investment decisions are contingent upon the degree of property rights contracts enforcement, and this, in turn, depends on the level of bureaucratic corruption, as enforcement needs a certain degree of non-corruption. More precisely, the decision to invest depends indirectly on three factors regarding the bureaucracy: its size, its degree of corruption, and the probabilities of corruption being detected. Quite clearly, corruption levels depend on the latter variable, plus the level of public wages. If bureaucrats are caught taking bribes, they lose their wages and the bribes. But paying high wages is costly, because it 
attracts talents with no comparative advantage for the public sector. In sum, the paper presents the tradeoff between property rights contract enforcement and the allocation of talent, understood as more people applying to the private sector. The result of the optimization made by a social planner is to set the wages at the maximum degree of bureaucratic corruption that still allows the enforcement of property rights and investment. This is even more pronounced when productivity is lower, as is the case in many of the less developed countries. Only under certain conditions there is a so called "free-lunch" effect, where higher wages result in: a) less corruption; b) a smaller bureaucracy and a larger number of agents who work in directly productive jobs and c) a better allocation of talent.

Acemoglu (2005) presents a model seeking to outline the effects of state strength on the economy. The article attempts to fill the gap regarding the tradeoff between the distortions posed by self-interested rulers with taxation power, and the inefficiencies that arise from the lack of state authority. For this, it builds on the typology by Migdal (1988) on weak and strong states, and the tradeoff between the power of the state versus the power of society. A state can be weak or strong both politically and economically: in politically weak states rulers can be replaced easily, while economically weak states have low capacity to tax. Rulers need to choose between the use of public resources for their own consumption or devoting them to the provision of public goods. In this model, too weak and too strong states (both economically and politically) create distortions. In weak states rulers cannot derive high future benefits from public investments, and therefore choose to underinvest in public goods and state capacity. When states are too strong they can impose such high taxes that the economy can lose vigor. The ideal scenario is somewhere in the middle, a situation in which rulers can tax and have incentives to invest in public goods. An equilibrium named consensually strong state exists if the state is politically weak but high taxes are imposed. This state explains the inverse relationship commonly observed between taxing capacity and executive constraints, and it emerges when decreases in political power raise investments in public goods, and as a consequence citizens agree to pay higher taxes.

Acemoglu, Ticchi and Vindigni (2006 2011) present a model showing some mechanisms by which inefficient states arise and persist as a consequence of patronage politics. They consider that "societies with limited state capacity are those that invest relatively little in public goods and do not adopt policies that redistribute resources to the poor" (: 1). State capacity and state efficiency are somewhat equated and involve the abilities of a central authority to monitor bureaucrats. This capacity is in turn dependent on the previous year investments. Starting from a non-democratic regime, the article claims that a 
transition to democracy might foster the selection of an inefficient state by the rich elite in control. This happens as the elite captures democratic demands through patronage, and avoids redistribution demands. The use of patronage can become self-reinforcing and thus explain the persistence of inefficient states. After democratization, bureaucrats can vote for either the pro-poor or the pro-elite party. The electoral support of the bureaucracy is key to winning elections. Although the bureaucrats are by assumption poor, they find it more convenient to vote for the pro-elite party, as they foresee that the poor will demand changes in the bureaucracy in order to better redistribute rents through taxing policy. If the elite wins, bureaucrats receive convenient rents from the elite that would otherwise lose after efficiency-oriented reforms. The elite also gains from an inefficient state, as it avoids more taxes and redistribution. The emergence and persistence of inefficient states is more likely to occur when inequality between rich and poor is higher, because the rich elite is more prone to avoid redistribution and therefore allow higher rents for the bureaucracy. On the other hand, if rents are too high and become too costly for the elite, the latter might simply prefer to redistribute, pushing bureaucrats to adapt their demands accordingly.

Besley and Persson (2007 2008 2009) do extensive work on unraveling the determinants of state capacity. In this setting, capacity building is seen as an investment made by incumbents as a function of future levels of social valuation for public goods. These levels are allowed to vary exogenously according to different political and historical circumstances, so that capacity building acquires the format of investments under uncertainty.

In Besley and Persson (2008) they analyze how self-interested incumbents decide to use part of the government's revenue to invest in fiscal capacities that enable higher tax extraction from the society in the future. Raising public revenue is key to providing a higher level (or a better quality) of public goods, in this case exemplified by defense against external threats. They analyze how two types of exogenous conflicts, internal insurgency and external war, affect the value that society grants to public goods, and as a consequence, the relevance of investing in fiscal capacities. The model predicts that the expectation of future external conflict will raise today's investments in fiscal capacity, and all sectors of society will be taxed equally, such that revenue raising is optimized. In contrast, the expectation of future internal conflict has the opposite effect: as all fiscal capacity is destroyed when internal conflict occurs, the value of public goods decreases, incumbents favor their own group in society with redistribution, and no public goods are provided.

In an extended model (Besley and Persson 2007, 2009) they also analyze investments in legal capacity as an endogenous policy decision. Legal capacity is 
understood as the capacity to protect and enforce property rights, a marketsupporting institution. Apart from conditioning investments on internal and external conflict, they also show that other political factors can change the value of public goods, such as the level of inclusiveness of institutions (capturing political polarization), the level of political stability, and whether the political regime resembles that of a utilitarian planner or a politically-controlled one. Several derivations arise from their model: investments in legal and fiscal capacity are complementary; wealthier countries choose higher levels of both types of capacity; greater political stability raises investments in state capacity; a more representative political system (meaning, closer to the utilitarian planner ideal) also raises investments in both capacities; and finally, the higher the wealth of the ruling group, the higher the investments in legal capacity, and the lower in fiscal capacity.

One of the novelties of Besley and Persson's (2011) Pillars of Prosperity is that it includes the role of violence in the previous models and seeks to interact more closely with the literature on conflict and fragile states. It further adds complexity on the conceptualization of state capacity, and makes a special effort to distinguish policies from institutions. State capacity is seen as capital investment, and it has four dimensions: a) taxing, b) contract enforcing (called productive capacity); c) coercive (peace and order); d) regulatory/distributive: public goods provision. The authors point out that while most of the economic development literature takes for granted the ability of the state to perform these tasks, this is very much different for the development community on weak and fragile states. The book asks what determines the building of different capacities, and why are they complementary. In this framework, selfinterested governments decide upon policy depending on a set of constraints posed by the political institutions, and always seek to be re-elected. At the same time, their re-election depends on investments on violence, similarly to those who are out of power and maximize their opportunities to re-gain it. The conclusions show that stable politics, along with consensual institutions and a higher demand for public goods are more conducive to greater investments in state capacities. There is a particular emphasis on the importance of cohesive institutions. There are three resulting state types: a) common interest states; b) redistributive states and c) weak states (this typology is closely explored in Besley 2011). At the same time, the book explains the empirical pattern of clusterization of low income, fragile states and violence, by the existence of complementaries between state capacities. One very interesting angle of the book is that it explains how different types of foreign aid can affect state-building. For example, cash aid can help common-interest states, but has no effect when states are redistributive or weak. Infrastructure aid can raise private incomes and help stress the importance to build the state. 
Differently, military assistance can reinforce the power of the incumbent, and increase violence.

\subsubsection{Political and behavioral determinants of state capacity}

During the nineties, political science also advanced discussions on the determinants of state capacity, in this case centered around how different features of the political system such as constitutions, party systems, party discipline, or political survival, affect bureaucratic professionalization and policymaking capacity.

For Margaret Levi (1988), state capacity is the state's ability to provide collective goods by raising revenue. She follows the line of Tilly by studying the determinants of fiscal capacity, not subject to external conflict, but to internal political conditions instead. Taking on a rational choice approach, Levi contends that leaders are self-interested and revenue-maximizers for the whole of their tenure, as revenue "enhances the ability to extend rule" (: 2). The main hypothesis is that the chances to raise revenue and the organizational structures favored are affected by three main constraints. First, the insecurity of the leader's mandate duration. Leaders discount the future based on their expectations to remain in power, and normally political rivalries and insecurity lead to high discount rates. In these settings, extraction policy tends to be less concerned with damaging economic performance. Second, the transaction costs associated with revenue raising. It is assumed that agents will break contracts whenever it is convenient, depending on the costs associated to the changes. Policymakers need to lower transaction costs, as a tradeoff exists between revenue extraction and transaction costs. The latter are defined as "the costs of measuring, monitoring, creating and enforcing compliance" (: 12). A third constraint is the bargaining power of rulers. Rulers have more bargaining power if they can monopolize coercive, economic and political resources. Given these factors, creating compliance is a continuous interaction between rulers and citizens in the form of collective action problem. The book's main hypotheses find support through an empirical strategy that explores the variation in major tax policy choices as a consequence of changes in the three political constraints mentioned above. The historical case studies are chosen according to different levels of state development and the fact that all of them are in the midst of historical change: Ancient Rome, medieval England and France, Britain during the industrial revolution and post-World War II Australia ${ }^{10}$.

\footnotetext{
${ }^{10}$ An interesting operationalization of Levi's model can be found in Young (2009).
} 
Similarly, the book by Barbara Geddes Politican's Dilemma (1996) is a salient initiator of debates on how political institutions shape politicians' incentives to build administrative competence in Latin America. Her model lies somewhere in between intentional and structural approaches, where certain institutions constrain politicians' choices regarding administrative reform, and these choices, in turn, have an impact on the structure of the politics-bureaucracy interaction in the future. Geddes considers state capacity to be equated to the implementation power of the state, a task that falls inherently under the bureaucracy and is as important as decision-making. This implementation power depends on the possibility to count on a politically-insulated bureaucracy ${ }^{11}$, and the advancements in terms of merit-oriented administrative reform: "the capacity to implement state-initiated policies depends on the ability to tax, coerce, shape the incentives facing private actors, and make effective bureaucratic decisions during the course of implementation. All of these abilities depend in turn on the existence of effective bureaucratic organizations." (: 14). It is worth noting that in Geddes' understanding the state is not an actor with relatively autonomous preferences, but an entity consisting of self-interested individuals (presidents, legislators, party leaders and bureaucrats) who seek to maximize their career opportunities, somewhat similarly to Levi (1988). In this sense, the responses of these four types of politicians can be different depending on their career incentives. In unreformed systems, politicians can influence their reelection opportunities by using state resources (primarily jobs) in order to buy loyalties. When analyzing Latin American presidents' efforts to build state capacities, the author introduces the notion of politician's dilemma: a president faces a tradeoff between appointing competent state mangers who increase the chances of fostering growth and development, and appointing partisan managers to reassure their support. Both dimensions contribute to their career prospects, even in systems where immediate re-election is forbidden ${ }^{12}$. Administrative reform is seen as a collective action problem of the type iterated prisoner's dilemma, where cooperation to minimize the role of patronage through reform happens only if others are willing to cooperate as well: "Politicians who might otherwise consider offering reforms as a strategy for attracting support will not be able to afford the cost in lost political resources as long as they compete with others able to use such resources in the struggle for votes. This is the politician's dilemma. A politician might in some circumstances, however, be willing to give up this resource if

\footnotetext{
${ }^{11}$ The political insulation of agencies is a different idea from autonomy from societal and economic interests. Geddes considers that an efficient administration is not an administration that is autonomous from social or class demands, but an administration that is unaffected by particularistic political interests.

${ }^{12}$ The assumption is that presidents will want to run for elections at a later point, and having fostered growth in the past increases their chances of winning office again.
} 
everyone else were also willing."(: 42). Several interesting propositions arise from Geddes' model. First, whenever large parties are evenly represented in Congress -and therefore have equal access to patronage-, legislators will feel more inclined to pass administrative reforms. In the cases when this happens, and parties' strength remains stable over time, the likelihood of furthering and enhancing reforms also increases. In contrast, when some parties have a privileged access to patronage, it becomes rather easy for them to block reform, given the high costs of organizing collective action for the opposition. This situation is exemplified by the Brazilian case between 1946 and 1964, when the PSD-PTB governing coalition had an asymmetric access to patronage, and minority reform-oriented parties such as the UDN failed in bringing about reform. Second, those feeling in a more secure position within their parties will tend to promote reforms, while the weaker ones will need to use more state resources in order to buy or reassure political loyalties. Third, minority parties will always prefer reform preventing big parties from using patronage. Fourth, presidents coming from parties with greater party discipline will tend to favor reform more frequently. Fifth, electoral systems favoring personalized voting grant more value to patronage, and therefore disincentive reform. Sixth, presidents coming from new parties need to rely more on patronage to consolidate their organizational base, and thus the gains from reform are lower. Finally, when patronage is not evenly distributed, but there is strong pressure from society to introduce reform due to some political event, then political entrepreneurs gain substantially from reform in terms of career perspectives, regardless of how asymmetric the access to patronage is, and reform is also likely. Apart from the Brazilian case, Geddes offers empirical test for her predictions with other four Latin American countries: Chile, Uruguay, Colombia and Venezuela after 1930. In order to operationalize capacity, Geddes (1996) resorts to the Appointment Strategy Index, which consists of eight questions applied to forty-four Latin American constitutional governments. ${ }^{13}$

Weaver and Rockman (1993) compile a series of articles that present yet another approach to state capacities. In this case, state capacities are conceived as policymaking / governing capacities, which depend on the constraints and possibilities of the fundamental institutions embedded in the political system. The most important capacities are: a) to establish and maintain priorities

\footnotetext{
${ }^{13}$ These questions assess: a) whether the finance minister was chosen on the basis of partisanship or competence; b) whether at least 90 per cent of ministers belong to the president or coalition's party; c) whether second-tier appointments were concentrated among party or coalition members; d) whether party members voiced complaints regarding appointment strategies; e) whether the public sector jobs of party member were protected; f) whether hiring in previously unpoliticized government entities or recently nationalized industries depend on partisan criteria; g) whether there was progress in insulating previously uninsulated agencies; and h) whether scandals regarding partisan hiring appeared in the press.
} 
among multiple and contradictory demands; b) to allocate resources in an optimal manner; c) to innovate when old policies fail; d) to coordinate contrasting objectives into a coherent whole; e) to be able to impose loses on powerful groups; f) to represent diffuse interests; g) to guarantee an effective implementation of policies; h) to guarantee some level of policy stability; i) to formulate and sustain international commitments regarding trade and national defense; j) to manage societal divisions in order to avoid internal war. These capacities will depend on certain constitutional features of the political system such as power division arrangements, the organizational autonomy of bureaucracies, federalism, the electoral rules, and the number of congressional chambers, among others. A series of case studies illustrate the causal mechanisms at work across several modern economies and different policy areas. In their conclusions, Weaver and Rockman argue that some tradeoffs exist between state capacities, as in the case, for example, of policy stability and policy innovation. Countries with separation of powers or coalition governments offer good opportunities for policy stability but less for policy innovation. In contrast, countries with single party domination (such as the UK), grant opportunities for policy innovation, as a substantial proportion of the political elite changes with every election. The book highlights other important findings: the impact of the political system on policymaking capacity depends greatly on the policy area; and policy inheritances also explain many of these results (: 446-461).

The essay by Guy Peters (1996) The Policy Capacity of Government seeks to offer a comprehensive understanding of the many factors hindering central governments' capacity to design and implement policies that meet their goals, a seemingly contemporary challenge of industrial democracies in comparison to the sixties and seventies. The essay argues that this erosion occurs as a result of increasing globalization, which impedes full domestic control over policies and programs, in addition to increased pressures from the private sector. Another reasons points at the fact that policymaking has become more politicized and ideological over time; that public servants emphasize now implementation goals instead of good policy analysis; and that more public participation leaves less ground for autonomous policymaking.

Parallel to the importance given to autonomous policymaking, the work of Bo Rothstein Social Traps and the Problem of Trust (2005) centers on the relevance of impartial and universal policymaking as critical features of state capacity building and good governance, two concepts largely intertwined. He proposes a series of feedback mechanisms between individual and institutional trust and the ways in which appropriate state intervention can foster both. The argument suggests that corruption and lack of good governance stems from low social capital understood as low inter-personal trust, which leads to 
the failure of cooperation between citizens, even when it could be beneficial for all. This situation is characterized as a 'social trap', a recurrent phenomenon in poor institutional settings spanning many aspects of life, which reinforces the generalized mistrust at the institutional level.

At the same time, these low social capital levels have their origins in low levels of both equality of substance and equality of opportunity, the latter defined as "the establishment of public policies that are intended to create equal conditions for citizens regardless of their income, ethnic/religious background, sex, and race in areas such as health care, education, and social security and legal protection ('equality before the law')." (Rothstein and Uslaner 2005: 42). So although the mistrust is born out of individual beliefs, certain interventions "from above" by state officials can instill more trust by equalizing conditions among citizens, through universal policies and impartial administration. Universal programs increase social trust in three ways: by representing more redistributive options than focal policy; by minimizing bureaucratic discretion and increasing the sense of "equal opportunity"; and by minimizing in-group trust in favor of generalized trust (Rothstein and Uslaner 2005: 43). The rationale is supported by a detailed historical account of Swedish capital-labor relations as examples of corporatist mechanisms for promoting social trust, as well as a set of cross sectional estimations on the link between social trust and trust in institutions.

Van de Walle and Scott (2009) analyze three mechanisms by which public services have an impact on state-building process in Western Europe during the 17th - 19th centuries. A first mechanism is penetration, where public services serve the purpose of consolidating presence and authority over a territory; standarization, helping create a shared set of habits and cultural traits; and accommodation, a mechanism aimed at optimizing the exchanges between the state and the citizens according to different idiosyncratic features.

Bäck and Hadenius (2008) present a statistical analysis of the relationship between democracy and state capacities. There, they find a J-shaped relationship between the two, by which democracy has a negative effect on state capacity at low levels of democracy, and strongly positive at high levels. In a study of the evolution of state capacity in 26 post-communist countries, Fortin (2010) finds that the initial level of state capacity is the strongest determinant of subsequent levels, measured through a five-item index of capacity.

Dahlström and Lapuente (2010) analyze how the separation of interest between those who benefit from public administration incentives (politicians) and those who manage them (civil servants) affects the chances of introducing performance-related pays (PRP), a characteristic feature of New Public Management reforms. They argue that the clearer the separation of interest, 
the higher the probability of engaging in PRP, as it helps overcome timeinconsistency problems. Employers will be more likely to trust and commit to produce whenever they know that the 'owners' cannot manage (in this case change) the payment arrangements ex-post. They test these predictions with data from 25 OECD countries.

Charron and Lapuente (2010) analyze the effect of democracy on quality of government, against the backdrop of the non-linear relationship previously found in the literature. Quality of government is used interchangeably with state capacity and is defined as: "the capacity of a state to perform its activities in an efficient way and without corruption". The article posits that the effect of democracy on quality of government is conditional on countries' wealth. Below a certain wealth threshold, governments have no incentives to invest in bureaucratic endowments, while in richer countries this becomes more sensible. This is tested and supported with time-series and cross-sectional data for a large number of countries, where quality of government is measured through the combination of Control of Corruption and Bureaucratic Quality from ICRG, following Bäck and Hadenius (2008), and democracy is measured through the average of Freedom House and Polity Scores taken from the Quality of Government Institute (Teorell et al. 2008).

The work of Knutsen (2013) links economic and political factors by presenting an empirical analysis of the separate and combined effects of regime type and state capacity levels on growth. It understands state capacity as the successful implementation of public policies through an efficient rule-following bureaucracy. This definition aims to include administrative, legal and fiscal dimensions of capacity (: 4), and is operationalized using the ICRG Bureaucratic Quality Index and the Statehist5 indicator of antiquity from Bockstette et. al. $(2002)^{14}$. Time-series estimations from a group of 45 Sub-Saharan countries suggest that democracy has a higher effect on growth in low-capacity countries than in dictatorships, whereas political regime has an insignificant effect in high capacity states. The interaction effects are also found after testing different linear transformations of BQI and Statehist5. These findings challenge common views pointing at the detrimental effects of democracy in low capacity states (for the African case, for instance, Chabal and Daloz 1999; Lumumba-Kasongo 2005). Knutsen argues that democracy limits survival-oriented behavior in low capacity states, as there is a substitutability relationship between democracy (vertical accountability) and state capacity (horizontal accountability).

\footnotetext{
${ }^{14}$ For robustness purposes it also resorts to a measure of fiscal capacity (1-Trade Tax/Government Revenue).
} 


\section{State capacities: concepts and measures}

The previous section provided an overview some of the most relevant works estimating the determinants and consequences of state capacity in development economics, international relations, political economy and comparative politics. The present section presents a schematic summary of the conceptualizations and measurements, in order to better judge the methodological challenges ahead. The measures of state capacity seen in the literature also show a great deal of variation. Some of them acknowledge the existence of several aspects or dimensions, while others aim to capture state capacity in a generic way.

\subsection{A multidimensional concept}

In general, state capacity refers to one or a combination of the following dimensions of state power: a) coercive/ military; b) fiscal; c) administrative / implementation; d) transformative or industrializing; e) relational/territorial coverage; f) legal; g) political. A chronological list of the conceptualizations can be found in Figure 1, while Figure 2 shows a list of some of the most popular measures used for empirical work.

\subsubsection{Coercive capacity}

The most basic attribute of stateness in virtually every definition, is the state's capacity to monopolize the administration of coercive power. Although this dimension was the center of classic macrohistorical accounts on state formation, it was largely forgotten until it resurfaced in the early 2000's after the world witnessed multiple events of state collapse. The conflict literature in international relations started to reassess the military capacity of states to control the territory by both discouraging internal conflict and protecting the borders from external invasion. Much of the economic literature that looked at limited government as a synonym of institutional maturity started to acknowledge that an effective state has to exist in first place, in order to discuss property rights and executive constraints. For this purpose several sources of information were compiled within the state fragility literature, such as the State Failure Index (Polity IV); the State Fragility Index, the Index of State Weakness, the Fragility Index (from Country Indicators for Foreign Policy), the Failed State Index, Failure of Task Force, Forecast of State Failure (Fortin 2010). 


\section{Figure 1: State capacity conceptualizations in the literature}

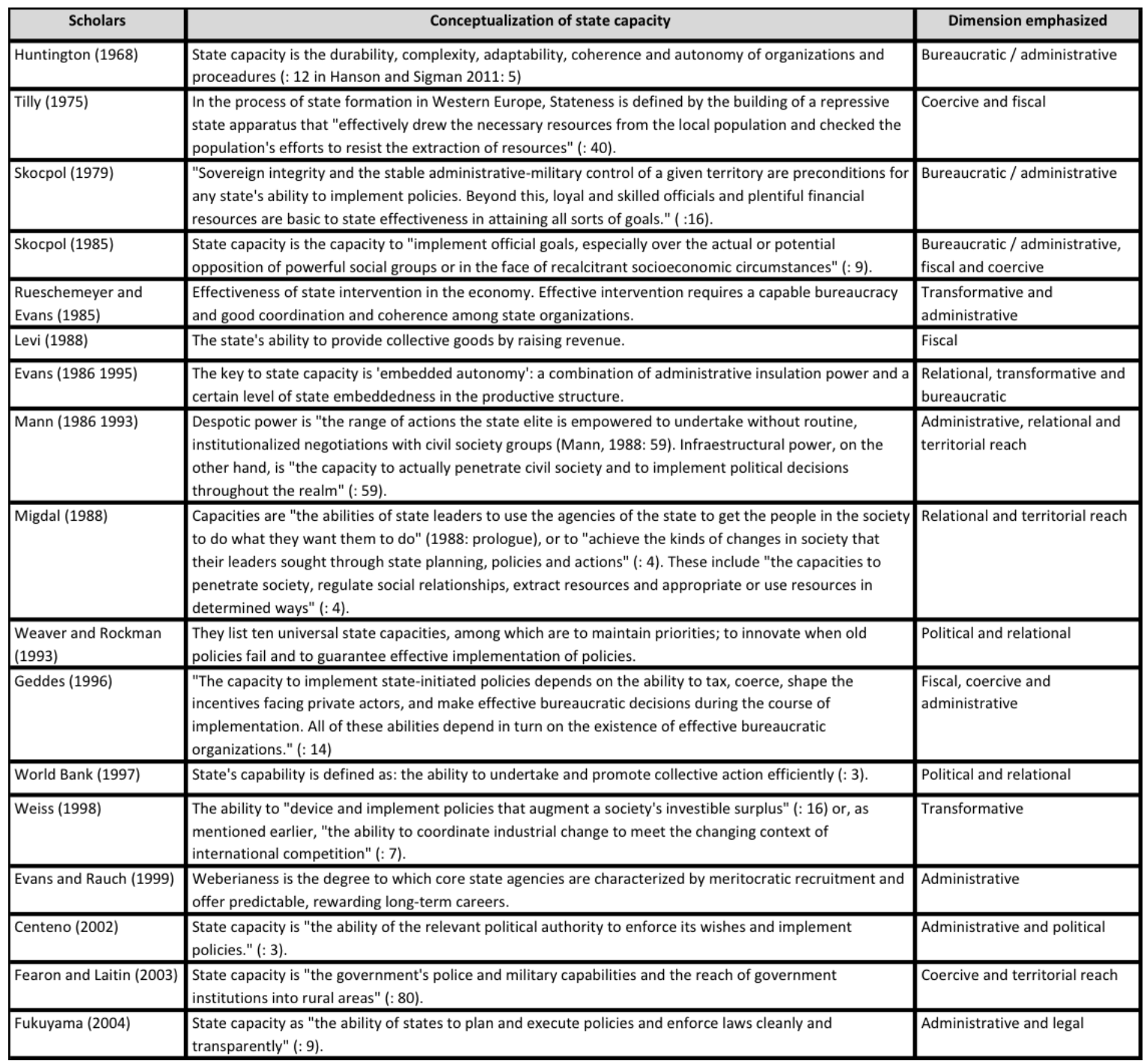


Figure 1: State capacity conceptualizations in the literature (cont.)

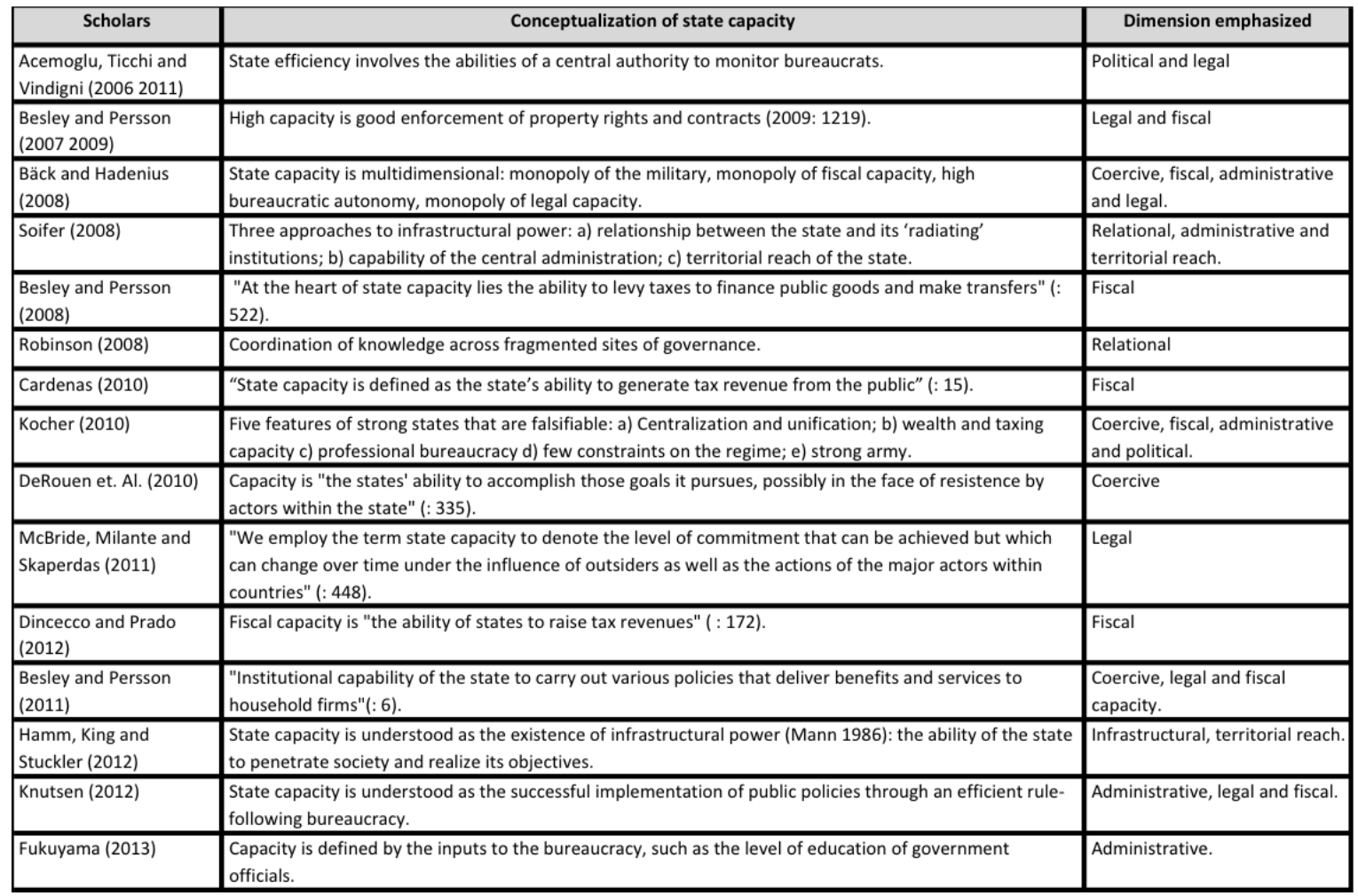

Source: author's elaboration.

\subsubsection{Fiscal capacity}

This dimension emphazises the state's power to extract resources from the society, mainly in the form of tax. Occasionally, it also refers to the efficiency of government spending (e. g. Dincecco 2011). In some strands of literature, the origins of this extractive capacity are closely linked to the building of a repressive apparatus and war (Tilly 1975), while in others it is associated more generally with the provision of public goods (e. g. Levi 1988). The historical processes by which states are able to centralize the tax system and enforce it on the larger population are key to state capacity building in these works, and measures of revenue raising are the usual proxies for capacity (Besley and Persson, various). 


\subsubsection{Administrative / Implementation capacity}

The administrative capacity of the state is rooted in the Weberian tradition regarding the modern state and the existence of a professional and insulated bureaucracy (e. g. Weber 1978). This type of bureaucracy outlives rulers and is deemed as an essential for the impersonal implementation of policies. In general, it is conceived that implementation capacity occurs only after an effective establishment of sovereignty and a stable military control over territory, and requires both skilled officials and financial resources (Skocpol 1985: 16). This dimension of state capacity is perhaps the most widely referred to in the literature, and often times closely related to good governance (E.g. Fukuyama 2004, 2013).

\subsubsection{Transformative, industrialization capacity}

Another strand looks at the state's capacity to intervene in a productive system and shape the economy. From here stems most of the 'developmental state' literature that looks at industrialization capacity. Some of these works are also loyal to a Weberian approach by contending that a balanced combination of professional cadres in the bureaucracy, proper levels of intra-state agency coordination and a certain degree of state 'embeddedness' in the productive structure are the key to transformative capacity (Rueschemeyer and Evans, 1985; Evans 1995). On a similar vain, others look not only to transformative capacity but also distributive and innovative capacity (e.g. Weiss 1998).

\subsubsection{Relational / territorial coverage}

The state's relational capacity is mainly an interest of political sociology studies and is perhaps of a broader nature than other dimensions. It seeks to capture the extent to which the state actually permeate through the society and is able to internalize social interactions within its actions. The work of Migdal (1988) reflects some of this concern by assessing state's strength as a result of the type of interaction with the society. Relational capacity looks at socio-economic engagement, as opposed to the 'command-hierarchy' traditional view of the state (Robinson 2008). For example, the idea of infrastructural power (Mann 1986 1993) -the capacity to implement decisions throughout the jurisdiction- as something opposed to the despotic power to dictate legislation reflects this dimension of state capacity, perhaps closely related to implementation. According to Soifer (2008), Mann's idea of infrastructural capacity had several ramifications (see Soifer and Vom Hau 2008 and 
Soifer 2008). and has been understood as a) the administrative capabilities of the central state; b) territorial reach; c) the power of the state's 'radiating institutions', how the state affects and is limited by civil society. Because of all these interpretations, relational capacity often encompasses several of the other dimensions.

\subsubsection{Legal capacity}

The legal dimension of state capacity has its roots in the 'limited government' strand of the literature, in which special attention is given to the limitation of state's intervention. Limitation happens through the existence of a stable legal system that enables credible commitments and contract enforcement (North 1981, North and Weingast 1989, Besley and Persson 2007, 2009). In this strand, state capacity is usually captured through the levels of bureaucratic corruption (e. g. Acemoglu and Verdier 1998) or executive checks (Acemoglu 2001). In the latest years, however, this tradition has acknowledged the importance of the existence of a strong state as a necessary condition to foster a market economy, and thus has tended to grant paralell attention to coercive capacity in poor or fragile states (a good example is the evolution in the work of Besley and Persson 2011).

\subsubsection{Political capacity}

In some cases, state capacity is equated to political leverage or policymaking capacity. The links with state capacity, however, are conceptually weaker than in other dimensions (see Hendrix 2010). It often refers to the level of power accumulation by elected leaders in order to enforce their policy priorities across the different institutional players (party, Congress, etc.) (Weaver and Rockman 1993; Tsebelis 1995; Gates et. al. 2006). This literature looks at veto points and executive checks, often sharing insights with the legal capacities literature.

\subsection{Tests of dimensionality}

A few works have sought to test the dimensionality of the state capacity concept within the conflict literature by pooling a large set of empirical measures and running factor analyses.

Hendrix (2010) argues that three main types of capacity have been often recognized: military capacity, administrative or bureaucratic capacity and quality 


\section{Figure 2: State capacity measures in the literature}

\begin{tabular}{|c|c|c|c|}
\hline Authors & Measurements of state capacity & Source & $\begin{array}{c}\text { Dimension of state capacity } \\
\text { emphazised }\end{array}$ \\
\hline Geddes (1996) & $\begin{array}{l}\text { Appointment Strategy Index: a composite indicator measuring } \\
\text { wheather the criteria for executive appointments is partisan or } \\
\text { competence-based. Also, state capacity is approximated by the } \\
\text { number of administrative reforms. }\end{array}$ & Author's elaboration. & Bureaucratic / administrative \\
\hline $\begin{array}{l}\text { Evans and } \\
\text { Rauch (1999) }\end{array}$ & $\begin{array}{l}\text { 'Weberianness' of the state: Weberian State Dataset, measuring } \\
\text { meritocratic recruitment, salary arrangements and career paths. }\end{array}$ & $\begin{array}{l}\text { Authors' elaboration: } \\
\text { Weberianess Survey (UCSD) }\end{array}$ & Bureaucratic / administrative \\
\hline \multirow[t]{2}{*}{ Centeno (2002) } & Date of first national census. & Goyer et. Al. (1983) & Infrastructural / generic \\
\hline & Railroad density in 1900. & Mitchell (1983) & Infrastructural / generic \\
\hline $\begin{array}{l}\text { Bockstette, } \\
\text { Chanda and } \\
\text { Puttermann } \\
(2002)\end{array}$ & Statehist5: index of state antiquity. & Authors' elaboration. & Generic \\
\hline \begin{tabular}{|l|} 
Fearon and \\
Laitin (2003) \\
\end{tabular} & Log of GDP per capita. & & Generic \\
\hline $\begin{array}{l}\text { Bäck and } \\
\text { Hadenius (2008) }\end{array}$ & Bureucractic Quality and Control of Corruption. & ICRG-PRS Group. & Bureaucratic / administrative \\
\hline \multirow[t]{3}{*}{ Soifer (2008) } & $\begin{array}{l}\text { National capabilities regarding national revenue and expenditures } \\
\text { in Western Europe. }\end{array}$ & $\begin{array}{l}\text { E.g.: Mann (1993) and } \\
\text { Straus (2006) }\end{array}$ & Bureaucratic / administrative \\
\hline & $\begin{array}{l}\text { Territorial variation in the ability of the state to compel } \\
\text { compliance. }\end{array}$ & $\begin{array}{l}\text { E.g.: Kalyvas (2006), } \\
\text { Goodwin (2001) and Soifer } \\
\text { (2006). }\end{array}$ & Territorial control \\
\hline & Effects of state policy on social identity. & $\begin{array}{l}\text { E.g.: Weber (1976) and } \\
\text { Vaughan (1997). }\end{array}$ & Relational capacity \\
\hline \multirow[t]{3}{*}{\begin{tabular}{|l|} 
Besley and \\
Persson (2008)
\end{tabular}} & Tax collection as share of GDP. & \multirow{3}{*}{ Baunsgaard and Keen (2005) } & Fiscal / Extractive \\
\hline & Income tax as share of total tax. & & Fiscal / Extractive \\
\hline & Average inflation rate. & & Fiscal / Extractive \\
\hline \multirow[t]{8}{*}{\begin{tabular}{|l|} 
Besley and \\
Persson (2009) \\
\end{tabular}} & Private credit to GDP ratio. & King and Levine (1993) & Legal \\
\hline & Access to credit (rank). & \multirow{2}{*}{ Doing Business } & Legal \\
\hline & Investor protection (rank). & & Legal \\
\hline & $\begin{array}{l}\text { Index of government anti-diversion policies (sum of five different } \\
\text { indicators). }\end{array}$ & ICRG-PRS Group. & Legal \\
\hline & One minus the share of trade taxes in total taxes. & \multirow{4}{*}{ IMF / WDI } & Fiscal / Extractive \\
\hline & One minus the share of trade and indirect taxes in total taxes. & & Fiscal / Extractive \\
\hline & Share of income taxes in GDP. & & Fiscal / Extractive \\
\hline & Share of taxes in GDP. & & Fiscal / Extractive \\
\hline
\end{tabular}


Figure 2: State capacity measures in the literature (cont.)

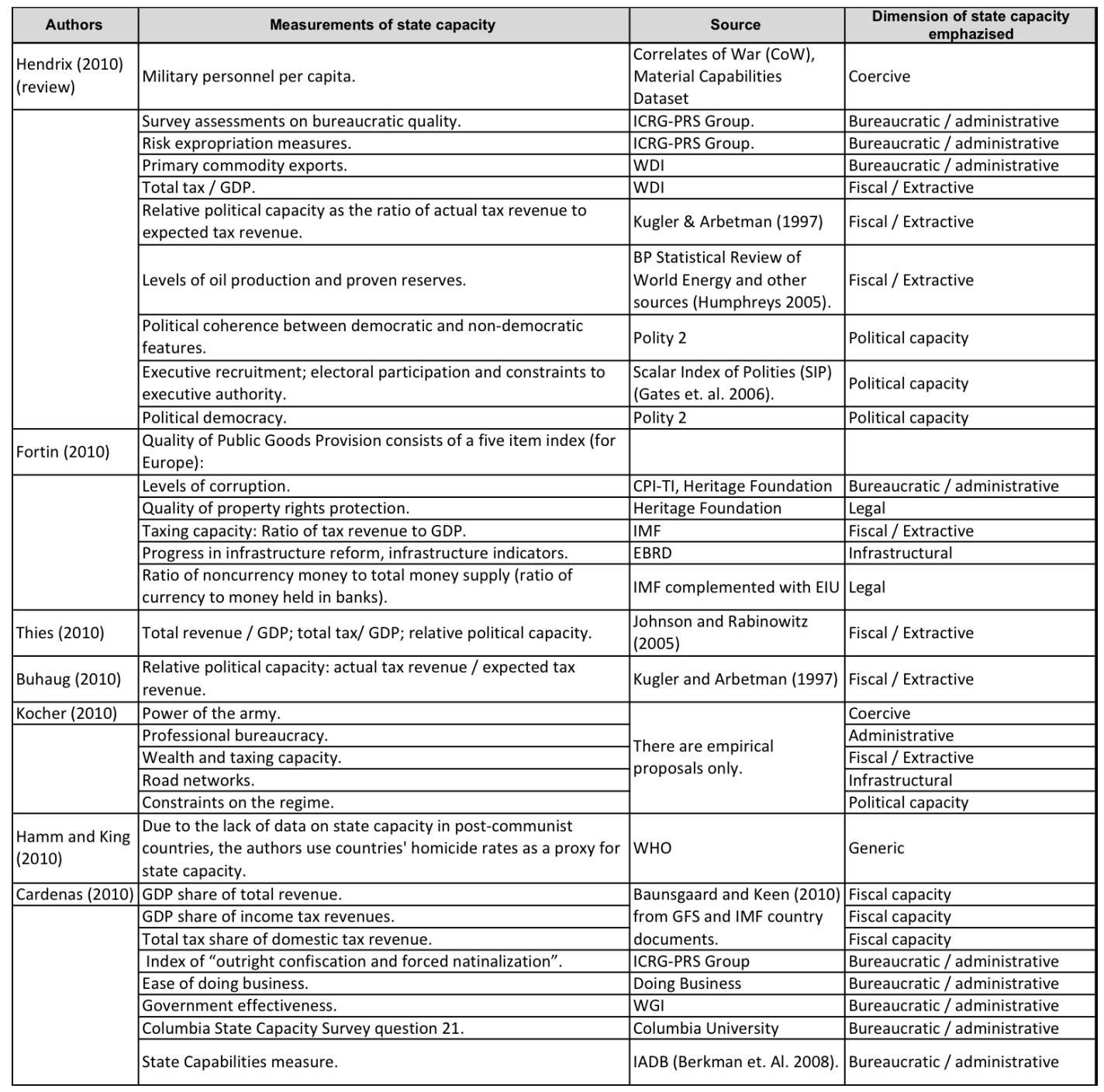




\section{Figure 2: State capacity measures in the literature (cont.)}

\begin{tabular}{|c|c|c|c|}
\hline Authors & Measurements of state capacity & Source & $\begin{array}{c}\text { Dimension of state capacity } \\
\text { emphazised }\end{array}$ \\
\hline \multirow[t]{2}{*}{$\begin{array}{l}\text { Cardenas, } \\
\text { Eslava and } \\
\text { Ramirez (2011) }\end{array}$} & $\begin{array}{l}\text { Cross country analysis: Total tax revenue as a percentage of GDP; } \\
\text { income tax as a percentage of GDP; Quality of Government Index } \\
\text { (average of law and order, corruption and bureaucratic quality } \\
\text { from ICRG). }\end{array}$ & $\begin{array}{l}\text { Baunsgaard and Keen } \\
\text { (2010); IMF (GFS); Quality of } \\
\text { Government Insitute; ICRG. }\end{array}$ & Fiscal and legal capacity \\
\hline & $\begin{array}{l}\text { Sub-national analysis for Colombia: tax revenue and expenditure } \\
\text { in roads. }\end{array}$ & Drazen and Eslava (2010) & Infrastructural / generic \\
\hline \multirow{11}{*}{$\begin{array}{l}\text { Hanson and } \\
\text { Sigman (2011) } \\
\text { (review) }\end{array}$} & Census frequency & UN Statistics & Territorial control \\
\hline & Proportion of Contract Intensive Money (CIM) & WDI online & Legal \\
\hline & Road density & $\begin{array}{l}\text { International Roads } \\
\text { Federation - WDI }\end{array}$ & Infrastructural \\
\hline & State Antiquity Index & Bockstette et. Al. (2002) & Generic \\
\hline & Total tax revenue & IMF - WDI & Fiscal / Extractive \\
\hline & Income tax revenue & IMF - WDI & Fiscal / Extractive \\
\hline & Tax revenue from goods and services & IMF - WDI & Fiscal / Extractive \\
\hline & Taxes on international trade & IMF - WDI & Fiscal / Extractive \\
\hline & Military personnel per capita. & $\begin{array}{l}\text { Correlates of War (CoW), } \\
\text { National Material } \\
\text { Capabilities v.3.02 }\end{array}$ & Coercive \\
\hline & Military spending (as \% of Government Expenditures) & CoW and CNTS & Coercive \\
\hline & Military in politics & PRS - ICRG & Coercive \\
\hline \multirow[t]{3}{*}{\begin{tabular}{|l|} 
Besley and \\
Persson (2011)
\end{tabular}} & State Fragility index. & Polity IV & Coercive \\
\hline & $\begin{array}{l}\text { Legal capacity: index of protection of property rights in } 1997 \text { (ICRG } \\
\text { data). }\end{array}$ & ICRG-PRS Group. & Legal \\
\hline & Fiscal capacity: total taxes as share of GDP in 1999 (IMF data). & IMF & Fiscal \\
\hline \multirow[t]{2}{*}{ Knutsen (2012) } & Index of Bureaucratic Quality & ICRG-PRS Group. & Administrative \\
\hline & State Antiquity Index - Statehist5 & Bockstette et. Al. (2002) & Generic \\
\hline \multirow[t]{2}{*}{$\begin{array}{l}\text { Hamm, King } \\
\text { and Struckler } \\
(2012)\end{array}$} & $\begin{array}{l}\text { Changes in total government spending between } 1992 \text { and } 2000 \\
\text { (government spending in } 2000 \text { U. S. dollars expressed as the share } \\
\text { of } 1992 \text { spending). }\end{array}$ & WDI & Fiscal / Extractive \\
\hline & $\begin{array}{l}\text { Survey questions capturing firm managers' perceptions on state } \\
\text { efficiency, property rights compliance and corruption levels. }\end{array}$ & $\begin{array}{l}\text { EBRD Business Environment } \\
\text { and Enterprise Performance } \\
\text { Surveys. }\end{array}$ & Generic \\
\hline $\begin{array}{l}\text { Dincecco and } \\
\text { Katz (2012) }\end{array}$ & $\begin{array}{l}\text { Government revenue (1650-1913) and government spending } \\
(1816-1913) \text {. }\end{array}$ & $\begin{array}{l}\text { Data compilation in } \\
\text { Dincecco (2011). }\end{array}$ & Fiscal / Legal \\
\hline $\begin{array}{l}\text { Dincecco and } \\
\text { Prado (2012) }\end{array}$ & Share of direct taxes. & IMF & Fiscal \\
\hline
\end{tabular}

Source: author's elaboration. 
and coherence of political institutions. The results of principal factor analysis on 15 cross sectional measures suggests three dimensions: administrative capacity (includes fiscal capacity), rentier autocraticness and neopatrimoniality. He concludes that state capacities should be assessed in a multidimensional way, where survey questions about the bureaucracy and tax levels are the best alternatives. In particular, he argues that bureaucratic quality is a more satisfactory measure of bureaucratic capacity than other popular measures, such as repudiation of government contracts or expropriation risk (: 278).

Hanson and Sigman (2011) undertake a similar endeavor, by departing from the observation that the state capacity concept has been poorly systematized. A first question that arises and should be addressed with more clarity is the nature of the referred capacity, in other words, the capacity for what. They consider that the universe of states have at least six state functions: maintenance of order, protection of property rights, enforcement of contracts, provision of public goods and services, technical competence, and coordination of information and measures. At the same time, these functions can be encompassed in three state capacity dimensions: extractive, coercive and administrative (although the latter is broad enough to include the ability to deliver services, enforce contracts, and protect property rights, thus combining bureaucratic expertise and territorial reach). They assess whether these functions can be captured in 13 common measures of state capacity through factor analysis pooling observations from 116 countries for the period 1984-2007. The results allow to identify six capacity factors: a) administrative, b) territorial reach, c) trade, d) income tax, e) goods and services tax and f) coercive potential. In this sense, the three hypothesized dimensions can be captured, as the first two correspond broadly to administrative capacity, the next three refer to extractive potential and the last to coercion power.

\section{Methodological challenges}

After revisiting some of the most salient works on state capacity coming from multiple theoretical lenses, a series of methodological considerations can be pointed out regarding concept consistency, construct validity and observability among others ${ }^{15}$.

\footnotetext{
${ }^{15}$ For other critical appraisals of state capacity conceptualizations and measurements see Kjaer, Hester and Hansen (2002), Soifer (2008), Hendrix (2010), Kocher (2010), Savoia and Sen (2012).
} 


\subsection{Concept consistency or divergence?}

According to DeRouen et. al. (2010) state capacity is a term that has been used extensively, but often without a firm definition (: 334). When looking at a wide range of works, however, it can be observed that conceptualizations of state capacity have been rather consistent, with a majority of works pointing at the implementation power of the state stemming from a professionalized bureaucracy. This consistency is probably owed to the strong theoretical legacy of Weber, along with the follow up by the statist movement of the late seventies and eighties. Whenever definitions drift from the dominant one, they usually remain loyal to one or more of the dimensions analyzed. A slight drift occurs in the case of extractive capacity, and perhaps a bigger one with legal capacity. Coercive, extractive and implementation capacity are generally intertwined in the early literature (for example in Evans et. al. 1985), and consider higher state intervention power as higher capacity. The focus on legal capacity, property rights and contracts, on the other hand, comes from a different theoretical tradition that equates higher intervention potential with greater risk of predation and therefore lower governmental quality. This apparent contradiction between legal and implementation capacity is for the most part not really addressed, although some works have been able to offer insights that bring them together as substitutes (Acemoglu 2005) or as compliments (Besley and Persson 2009, Dincecco 2011). To a big extent, this difference is due to disciplinary and ideological differences (which are discussed later), and have implications for empirical work.

The focus on legal capacity maintains some commonalities with the mainstream definition by considering effective enforcement of property rights and contracts, also a type of implementation capacity. However, this apparent similarity masks a more fundamental question: whether the source of implementation capacity comes from power deploying institutions or from power limiting ones. Contract enforcement and property rights are linked to a sound legal system, which in turn stems from an independent judiciary and a strong legislative. Normally, these are considered power-limiting institutions, and from there the persistent emphasis on executive checks and legal security. The extractive and administrative dimensions tend to be more interested in a power-deploying institution like the bureaucracy. To some extent, what we could call the confusion between the capacity to do and the capacity to refrain from doing, also leads to an overlap between state capacity and good governance, where state capacity is proxied through common good governance indicators such as rule of law, transparency, democracy, etc. ${ }^{16}$. There is even

\footnotetext{
${ }^{16}$ The work of Savoia and Sen (2012) is a good example of this: it considers state capacity in a broad manner by incorporating measures of well-known 'good' governance indicators
} 
another angle to the conceptual complexity. In some cases the source of implementation capacity is not specified, often mixing up two types of powerdeploying sources, such as the circumstantial strength of elected leaders, and that of the permanent bureaucracy. The stress on coercive capacity in fragile contexts, or some of the works on political or institutional capacity might point at the first ones, while administrative or infrastructural capacity point at the second. The methodological problem arises when all the different sources lead to implementation capacity, but the sources have contrasting incentives and what makes one weaker makes the other stronger.

\subsection{Measurements}

\subsubsection{Multidimensionality}

There are in general three types of approaches to measuring state capacity: choosing single generic measures; choosing a narrow one-dimensional definition with matching proxies; and choosing a composite multi-dimensional index (or various separate measures for separate dimensions).

The first strategy is the most often encountered in economics and international relations literature, where large- $\mathrm{N}$ statistical studies are predominant. Some of these are rather far from the common conceptualizations of state capacity, such as the use of GDP per capita by Fearon and Laitin (2003) or murder rates (Hamm and King 2010). Kocher (2010) offers a critical analysis of generic measures of state capacity. Other generic measures, however, are more successful at capturing bureaucratic structures or some form of implementational aspect, such as railroad density (Centeno 2002), censuses conducted (Centeno 2002) and similar measures of statistical capacity (Lee and Zhang in Fukuyama 2013; Hartie School governance indicators) or some of the latest experiments, such as the one testing cross-country courier service quality (La Porta et. al. 2012). State antiquity (Bockstette et. al. 2002) is also a generic measure that has been quite extensively used as a generic proxy of state capacity.

The second strategy is perhaps the most common, where the focus of the study is bounded by the literature and the interests belonging to one aspect of capacity. Sometimes the dimension of interest matches the measures with clarity (as is normally the case of fiscal capacity), while other times the match is less straightforward (for example when legal capacity is proxied through executive constraints).

In some cases, the acknowledgment of multiple dimensions of capacity has led

(property rights, regime type, checks and balances, etc.). 
to composite or aggregate indicators accounting for many different aspects, a strategy to overcome the inherently broad nature of state capacity. Fortin (2010) combines corruption (often seen as administrative capacity), property rights protection and noncurrency money (legal capacity), taxing measures (fiscal capacity), infrastructure reforms (infrastructural aspects). Similarly, Kocher (2010) resorts to power of the army (coercive), bureaucratic professionalism (administrative), taxes (fiscal), road networks (infrastructural) and constraints to the executive (legal).

In any case, the lack of good conceptual frameworks can create important problems. On one hand, it can lead to blunt contradictions (for example, is the power of the army directly or inversely related to state capacity?). On the other, it can lead to the use of theoretically opposed outcome variables as alternative measures of the same concept (as for example in the case of legal and fiscal capacity in Besley and Persson 2008 2009), even if they are positively associated in the real world.

\subsubsection{Dimensionality tests: problems}

The latter point leads to favor cautious interpretations of dimensionality test results, which may lead to amorphous constructs (constructs containing very different attributes inside) on the mere basis of strongly positive associations. For example, although Dincecco (2011) shows that in Europe extractive capacity and limited government evolved in parallel, the two are different things, from any conceptual perspective. Also, the fact that the existing dimensionality tests on state capacity (Hendrix 2010; Hanson and Sigman 2011) derive such different results, suggests that there is a need for further exploration. In addition, these results may be highly sensitive to changes in the temporal scope of the variables ${ }^{17}$, which raises questions about robustness and the need to run additional sensitivity analyses.

\subsection{Observability and circularity}

On a more subtle level, the state capacity concept faces some logical challenges. Since any capacity is the potential of doing something rather than a realization, the direct observability of this ability is a concern. Output measures are normally taken as proxies, but this strategy has raised persistent criticism (see Hanson and Sigman 2011 for the problems of output measures of state capacity and Fukuyama 2013 for output measures of institutions more generally).

\footnotetext{
${ }^{17}$ As is the case in Hendrix (2010).
} 
As Kocher (2010) suggests, the main problem is the resulting quasi-tautology of the kind: "why is there high insurgency in this country? Because there is low state capacity. How do I know that there is low state capacity? Because I observe high insurgency". Generic measures of state capacity reproduce this problem (e.g. GDP per capita, road density, murder rates). Similarly, Soifer (2008) highlights circularity problems in the measurement of state infrastructural power: "scholars need to measure infrastructural power in a way that distinguishes power from its effects, and this is often difficult to do". And moreover, "Because we have no independent measure of the increased weight of the state apparatus from its effects, a convincing demonstration that the state has had an effect requires the elimination of alternative explanations for the observed effects" (: 247). Given these problems, the literature is left with the paradoxical task of having to measure implementation capacity without being truly able to look at implementation results whenever other factors exist which mediate between these two.

\subsection{State functions: contextual, ideological and disciplinary lenses}

As several authors point out, a first important question to address regarding state capacity is: capacity for what? (Hanson and Sigman 2011). Different works define state capacity depending on the type of state function they are interested in, and sometimes capacities and functions are used interchangeably (e. g. Weaver and Rockman 1993). A careful handling of this connection is important in order to place state capacities in a broader perspective. The determination of which state functions matter depends on contextual, ideological and disciplinary aspects.

Regarding the first, certain functions can be more important in certain contexts than others, depending on the stage of development. The interest in coercive capacity, for example, becomes of relevance only in scenarios of total state collapse, although these are rare occurrences world-wide (Fortin 2010: $656)$.

Discussions on state functions are also largely ideological: to which extent is state intervention important and how should it be executed depends on notions of equality and freedom, among many others. Whether the state should be developmental or liberal will shape definitions and operationalizations of state capacity.

Finally, disciplinary boundaries matter in a similar fashion. According to Acemolgu (2005): "A tension has existed between political economy and polit- 
ical science regarding the state: whereas the former tended to promote less state intervention, the latter focused on the limitations arising from the lack of power to regulate the economy" (2005: 1199). A similar remark is made by Hanson and Sigman 2011: state capacities have been analyzed in economic development as protecting market exchanges by enforcing property rights, while in political studies, it has been associated to the maintenance of internal order. This consideration is in line with the distinction between legal capacities and the other dimensions that was outlined before.

\subsection{Temporal scope, determinism and policy implications}

It is possible to observe in the state capacity literature a noticeable lack of cross-national time series indicators, albeit some exceptions (e. g. Bureaucratic Quality from ICRG). This has to do with the difficulty in finding comparable and reliable data in time, in particular that are highly informative on relevant aspects of state capacity such as detailed bureaucratic structures and behavior $^{18}$. Another reason is that much of the literature has simply focused on largely deterministic factors that by nature entail very low intertemporal variance if any at all, or a trend that makes them difficult to work with in panel estimations. The strand that focuses on war prior to the modern state, for example, is illustrative of this. The measurement of state capacity through state antiquity is another example (Bockstette, Chanda and Putterman 2002). Other proxies such as road density or statistical capacity entail similar problems.

In contrast to the historical deterministic factors, much less attention is given to the microdeterminants of state capacity, and in particular to those with potential policy implications. Works on investments in state capacity are promising, but they remain highly close to deterministic theories on war and state formation (Besley and Persson, various) and barely look at the internal structures of states ${ }^{19}$. The focus on microdeterminants might be more frequent in studies of public administration, where output variables relate more to administrative reform or NPM measures, but where the concept of state capacity

\footnotetext{
${ }^{18}$ It has been pointed out that the lack of comparable empirical measures of the bureaucracy represents the main weak point in comparative public administration (Brans 2003, Lapuente 2007, Dalström et. al. 2010).

19 "Apart from this focus on legal capacity as a somewhat exogenous feature, works on the internal organization of states is scarce in the game-theoretic development economic literature" (Acemoglu, Ticchi, Vindigni 2006: 5). A partial exception to this is the literature on principal-agent issues in policymaking that looks into the politics-bureaucracy relation in a largely game-theoretic fashion. Yet, these are mostly micro-behavioral works not often translated into more structural arguments for development.
} 
becomes rather vague and all-encompassing. A good balance between concept richness and comparability anticipates the need to find a middle ground between the variables used in public administration, and the ambitions of larger-scope state capacity works to be counted in large $\mathrm{N}$ empirical studies on development.

\section{Lessons learned}

Research on state capacity is flourishing fast, perhaps faster than what is required to achieve consistency and construct validity. Because the term 'state capacity' invokes an idea that can rather easily be interpreted from common sense, there is a temptation not to define it or measure it with enough care, but resort to intuitive considerations. An extensive review shows that the resulting variance in conceptualizations is rather high, although it can be circumscribed within a limited and interrelated framework of categories. A series of lessons can be drawn from the works analyzed.

First, it is important that state capacity research explains with clarity which aspects of capacity will be assessed, and that scholars acknowledge the theoretical foundations of these aspects. This allows for a clearer understanding of potential weaknesses and limitations. Second, to achieve construct validity it is advisable that operationalizations match their concepts, and thus avoid capturing the wrong phenomena. Whenever the choice favors generic measures of state capacity, it is convenient that these measures do not overlap with other aspects of governance such as democracy, rule of law or power concentration. Third, it is analytically important that measures of capacity are suitable for time-series analysis, avoiding excessive path dependency. Fourth, whenever the choice favors multiple dimensions of state capacity, it is important that works bear in mind the primary source of this capacity (bureaucratic, political, judicial, etc.) in order to address potential contradictions between dimensions. Addressing the different incentives and mechanisms of different dimensions can prevent biases when outcome variables belonging to contrasting dimensions are used in empirical analyses. In particular, research should be careful in distinguishing what we called the 'capacity to do' and 'the capacity to refrain from', that separates power deploying from power checking sources of capacity.

The outlook looks promising nevertheless. The need for methodological improvements in the measurement of capacity will likely lead to take a richer and closer examination of national and subnational bureaucracies. More even as the mainstream definition continues to follow the notion of implementation 
power and professionalized civil service. In that sense, the literature might encounter the limitations of comparative public administration, a field that has failed in providing powerful empirical measures for comprehensive comparative analysis. This is of course, due to the great complexity involved in finding objective benchmarks for all administrations in the world, given the largely idiosyncratic nature of administrative apparatuses. To overcome some of these problems, a middle ground will need to be reached, even at the risk of loosing world-wide comparability. The famous tradeoff between methodological extension and intension flagged by Sartori (1970) is likely to play a role, where including more or new cases to be explained under the concept of state capacity requires that definitions are adjusted correspondingly. This might favor regional level studies, where the stage of state development tends to be more comparable. 


\section{References}

Acemoglu, D. (2005). Politics and economics in weak and strong states. Journal of Monetary Economics, 52(7):1199-1226.

Acemoglu, D., Ticchi, D., and Vindigni, A. (2006). Emergence and persistence of inefficient states. National Bureau of Economic Research Working Paper Series, No. 12748.

Acemoglu, D., Ticchi, D., and Vindigni, A. (2011). Emergence and persistence of inefficient states. Journal of the European Economic Association, 9(2):177-208.

Acemoglu, D. and Verdier, T. (1998). Property rights, corruption and the allocation of talent: a general equilibrium approach. The Economic Journal, 108(450):1381-1403.

Bach, D. C. (2011). Patrimonialism and neopatrimonialism: comparative trajectories and readings. Commonwealth and Comparative Politics, 49(3):275294.

Bäck, H. and Hadenius, A. (2008). Democracy and state capacity: Exploring a j-shaped relationship. Governance, 21(1):124.

Baunsgaard, T. and Keen, M. (2005). Tax Revenue and (or?) Trade Liberalization. International Monetary Fund.

Baunsgaard, T. and Keen, M. (2010). Tax revenue and (or?) trade liberalization. Journal of Public Economics, 94(910):563-577.

Berkman, H., Scartascini, C., Stein, E., and Tommasi, M. (2008). Political institutions, state capabilities, and public policy: an international dataset. Washington, DC, United States: IDB Research Department.

Besley, T. (2011). Pathologies of the state. Journal of Economic Behavior 83 Organization, 80(2):339-350.

Besley, T. and Persson, T. (2007). The origins of state capacity: Property rights, taxation, and politics. National Bureau of Economic Research Working Paper Series, No. 13028.

Besley, T. and Persson, T. (2008). Wars and state capacity. Journal of the European Economic Association, 6(23):522-530.

Besley, T. and Persson, T. (2009). The origins of state capacity: Property rights, taxation, and politics. American Economic Review, 99(4):1218-1244. 
Besley, T. and Persson, T. (2011). Pillars of Prosperity: The Political Economics of Development Clusters. Princeton University Press.

Bockstette, V., Chanda, A., and Putterman, L. (2002). States and markets: The advantage of an early start. Journal of Economic Growth, 7(4):347-369.

Braithwaite, A. (2010). Resisting infection: How state capacity conditions conflict contagion. Journal of Peace Research, 47(3):311-319.

Brans, M. (2003). Comparative public administration: from general theory to general frameworks. Handbook of Public Administration, Londres, Sage, pages $424-439$.

Buhaug, H. (2010). Dude, wheres my conflict? LSG, relative strength, and the location of civil war. Conflict Management and Peace Science, 27(2):107128 .

Cárdenas, M. (2010). State capacity in latin america. Economa, 10(2):1-45.

Cárdenas, M., Eslava, M., and Ramrez, S. (2011). External wars, internal conflict and state capacity: Panel date evidence. Latin America Initiative.

Cárdenas, M. and Tuzemen, D. (2010). Under-investment in state capacity: The role of inequality and political instability. Research working paper, The Brookings Institution.

Cárdenas, M. and Tuzemen, D. (2011). Under-investment in state capacity: the role of inequality and political instability. Research Working Paper RWP 11-07, Federal Reserve Bank of Kansas City.

Centeno, M. A. (2002). Blood and Debt: War and the Nation-State in Latin America. Penn State Press.

Chabal, P. and Daloz, J. P. (1999). Africa Works: Disorder as Political Instrument (African Issues). Indiana University Press.

Charron, N., Dahlstrm, C., and Lapuente, V. (2012). No law without a state. Journal of Comparative Economics, 40(2):176-193.

Charron, N. and Lapuente, V. (2010). Does democracy produce quality of government? European Journal of Political Research, 49(4):443-470.

Chaudhry, K. A. (1989). The price of wealth: business and state in labor remittance and oil economies. International Organization, 43(01):101-145.

Clodfelter, M. (2002). Warfare and armed conflicts: a statistical reference to casualty and other figures, 1500-2000. McFarland. 
Collier, P. and Hoeffler, A. (2004). Greed and grievance in civil war. Oxford Economic Papers, 56(4):563-595.

Dahlstrom, C. and Lapuente, V. (2010). Explaining cross-country differences in performance-related pay in the public sector. Journal of Public Administration Research and Theory, 20(3):577-600.

Dahlstrom, C., Lapuente, V., and Teorell, J. (2010). Dimensions of bureaucracy. a cross-national dataset on the structure and behavior of public administration. QoG Working Paper Series, 13.

DeRouen, K., Ferguson, M. J., Norton, S., Park, Y. H., Lea, J., and StreatBartlett, A. (2010). Civil war peace agreement implementation and state capacity. Journal of Peace Research, 47(3):333-346.

DeRouen, K. R. and Sobek, D. (2004). The dynamics of civil war duration and outcome. Journal of Peace Research, 41(3):303-320.

Dincecco, M. (2009). Fiscal centralization, limited government, and public revenues in europe, 1650-1913. Journal of Economic History, 69(1):48.

Dincecco, M. (2010). The political economy of fiscal prudence in historical perspective. Economics \& Politics, 22(1):136.

Dincecco, M. (2011). Political Transformations and Public Finances: Europe, 1650-1913. Cambridge University Press.

Dincecco, M. and Katz, G. (2012). State capacity and long-run performance.

Dincecco, M. and Prado, M. (2012). Warfare, fiscal capacity, and performance. Journal of Economic Growth, 17(3):171-203.

Drazen, A. and Eslava, M. (2010). Electoral manipulation via voter-friendly spending: Theory and evidence. Journal of Development Economics, $92(1): 39-52$.

Elias, N. (1982). The Civilizing Process: The history of manners. Oxford: Blackwell.

Erdmann, G. and Engel, U. (2007). Neopatrimonialism reconsidered: Critical review and elaboration of an elusive concept. Commonwealth and Comparative Politics, 45(1):95-119.

Ertman, T. (1997). Birth of the Leviathan: Building States and Regimes in Medieval and Early Modern Europe. Cambridge University Press.

Evans, P. and Rauch, J. E. (1999). Bureaucracy and growth: A cross-national analysis of the effects of "Weberian" state structures on economic growth. American Sociological Review, 64(5):748-765. 
Evans, P. B. (1989). Predatory, developmental, and other apparatuses: A comparative political economy perspective on the third world state. Sociological Forum, 4(4):561-587.

Evans, P. B. (1995). Embedded Autonomy. Princeton University Press.

Evans, P. B., Rueschemeyer, D., and Skocpol, T., editors (1985). Bringing the State Back In. Cambridge University Press.

Fearon, J. D. (2005). Primary commodity exports and civil war. Journal of Conflict Resolution, 49(4):483-507.

Fearon, J. D. and Laitin, D. D. (2003). Ethnicity, insurgency, and civil war. American Political Science Review, 97(01):75-90.

Fortin, J. (2010). A tool to evaluate state capacity in postcommunist countries, 1989-2006. European Journal of Political Research, 49(5):654-686.

Fukuyama, F. (2004). State-building: governance and world order in the 21st century. Cornell University Press.

Fukuyama, F. (2012). The strange absence of the state in political science. The American Interest. Blog entry, February 2012.

Fukuyama, F. (2013). What is governance? Working Paper 314, Center for Global Development.

Gates, S., Hegre, H., Jones, M. P., and Strand, H. (2006). Institutional inconsistency and political instability: Polity duration, 1800-2000. American Journal of Political Science, 50(4):893-908.

Geddes, B. (1996). Politician's dilemma: building state capacity in Latin America. University of California Press.

Goodwin, J. (2001). No Other Way Out: States and Revolutionary Movements, 1945-1991. Cambridge University Press.

Goyer, D. S., Domschke, E., and Draaijer, G. E. (1983). The Handbook of National Population Censuses. Greenwood Press.

Hamm, P. and King, L. (2010). Post-manichean economics: Foreign investment, state capacity and economic development in transition economies. Working Paper 227, Political Economy Research Institute.

Hamm, P., King, L. P., and Stuckler, D. (2012). Mass privatization, state capacity, and economic growth in post-communist countries. American Sociological Review, 77(2):295-324. 
Hanson, J. and Sigman, R. (2011). Measuring state capacity: Assessing and testing the options. Paper presented at the American Political Science Association conference.

Hendrix, C. S. (2010). Measuring state capacity: Theoretical and empirical implications for the study of civil conflict. Journal of Peace Research, $47(3): 273-285$.

Hout, W. (2007). Development under patrimonial conditions: Suriname's state oil company as a development agent. Journal of Development Studies, 43(8):1331-1350.

Humphreys, M. (2005). Natural resources, conflict, and conflict resolution uncovering the mechanisms. Journal of Conflict Resolution, 49(4):508-537.

Huntington, S. (1968). Political order in changing societies. New Haven.

Jessop, B. (2001). Bringing the state back in (yet again): Reviews, revisions, rejections, and redirections. International Review of Sociology, 11(2):149173.

Johnson, K. and Arbetman Rabinowitz, M. (2005). Relative political capacity model \& data description.

Karl, T. L. (1997). The Paradox of Plenty: Oil Booms and Petro-States. University of California Press.

King, R. G. and Levine, R. (1993). Finance and growth: Schumpeter might be right. The Quarterly Journal of Economics, 108(3):717-737.

Kjaer, M., Hansen, O., and Thomsen, J. (2002). Conceptualizing state capacity. Democracy, the State, and Administrative Reforms Research Report No, 6 .

Knutsen, C. H. (2013). Democracy, state capacity, and economic growth. World Development, 43:1-18.

Kocher, M. (2010). State capacity as a conceptual variable. Yale Journal of International Affairs, 5(2).

Krasner, S. D. (1984). Approaches to the state: Alternative conceptions and historical dynamics. Comparative Politics, 16(2):223-246.

Kugler, J. and Arbetman, M. (1997). Political capacity and economic behavior. Westview Press.

La Porta, R., Lopez-De-Silanes, F., Shleifer, A., and Vishny, R. (1999). The quality of government. Journal of Law, Economics, and Organization, 15(1):222-279. 
Lapuente, V. (2007). A Political Economy Approach to Bureaucracies. Doctoral dissertation, University of Oxford.

Lumumba-Kasongo, T. (2006). Liberal Democracy and Its Critics in Africa: Political Dysfunction and the Struggle for Progress. Zed Books.

Mann, M. (1986). The Sources of Social Power: A history of power from the beginning to A.D. 1760. Cambridge University Press.

Mann, M. (1993). The Sources of Social Power: The Rise of Classes and Nation-States, 1760 - 1914. Cambridge University Press.

McBride, M., Milante, G., and Skaperdas, S. (2011). Peace and war with endogenous state capacity. Journal of Conflict Resolution, 55(3):446 -468.

Migdal, J. S. (1988). Strong Societies and Weak States: State-Society Relations and State Capabilities in the Third World. Princeton University Press.

Miliband, R. (1969). The state in capitalist society. Basic Books, New York.

Mitchell, B. (1983). International Historical Statistics: the Americas. Gale Research, Detroit.

Moore, B. (1966). Social origins of democracy and dictatorship. Boston: Beacon.

Myrdal, G. (1968). Asian Drama: an Inquiry into the Poverty of Nations. Penguin, Harmondsworth.

Nordlinger, E. A. (1982). On the Autonomy of the Democratic State. Harvard University Press.

North, D. (1981). Growth and structural change. New York: Norton.

North, D. C. (1990). A transaction cost theory of politics. Journal of Theoretical Politics, 2(4):355 -367.

North, D. C. and Weingast, B. R. (1989). Constitutions and commitment: the evolution of institutions governing public choice in seventeenth-century england. The journal of economic history, 49(04):803-832.

Offe, C. (1972). Advanced capitalism and the welfare state. Politics $\&$ Society, 2(4):479-488.

Peters, B. G. (1996). The policy capacity of government. Canadian Centre for Management Development.

Popov, V. (2001). Reform strategies and economic performance of Russia's regions. World Development, 29(5):865-886. 
Poulantzas, N. (1974). Internationalisation of capitalist relations and the nation-state . Economy and Society, 3(2):145-179.

Rauch, J. E. and Evans, P. B. (2000). Bureaucratic structure and bureaucratic performance in less developed countries. Journal of Public Economics, 75(1):49-71.

Robinson, M. (2008). Hybrid states: Globalisation and the politics of state capacity. Political Studies, 56(3):566-583.

Roll, M. (2011). The State that works: Pockets of Effectiveness as a perspective on stateness in developing countries. Technical report, Arbeitspapiere des Instituts fur Ethnologie und Afrikastudien der Johannes GutenbergUniversitat Mainz.

Ross, M. L. (1999). The political economy of the resource curse. World Politics, 51(02):297-322.

Rothstein, B. (2005). Social traps and the problem of trust. Cambridge University Press.

Rothstein, B. and Teorell, J. (2008). What is quality of government? a theory of impartial government institutions. Governance, 21(2):165-190.

Rothstein, B. and Uslaner, E. M. (2005). All for all: Equality, corruption, and social trust. World Politics, 58(1):pp. 41-72.

Rueschemeyer, D. and Evans, P. (1985). The state and economic transformation: Toward an analysis of the conditions underlying effective intervention. In Evans, P. B., Rueschemayer, D., and Skocpol, T., editors, Bringing the State Back in. Cambridge University Press.

Sartori, G. (1970). Concept misformation in comparative politics. The American Political Science Review, 64(4):1033-1053.

Savoia, A. and Sen, K. (2012). Measurement and evolution of state capacity: Exploring a lesser known aspect of governance. Effective States and Inclusive Development Research Centre Working Paper, 10.

Skocpol, T. (1979). States and social revolutions: a comparative analysis of France, Russia, and China. Cambridge University Press.

Skocpol, T. (1985). Bringing the state back in: strategies of analysis in current research. In Evans, P. B., Rueschemayer, D., and Skocpol, T., editors, Bringing the State Back in. Cambridge University Press.

Skocpol, T. and Finegold, K. (1982). State capacity and economic intervention in the early new deal. Political Science Quarterly, 97(2):255-278. 
Skowronek, S. (1982). Building a New American State: The Expansion of National Administrative Capacities, 1877-1920. Cambridge University Press.

Sobek, D. (2010). Masters of their domains: The role of state capacity in civil wars. Journal of Peace Research, 47(3):267 -271.

Soifer, H. (2008). State infrastructural power: Approaches to conceptualization and measurement. Studies in Comparative International Development, 43(3-4):231-251.

Soifer, H. and vom Hau, M. (2008). Unpacking the strength of the state: The utility of state infrastructural power. Studies in Comparative International Development, 43(3-4):219-230.

Soifer, H. D. (2006). Authority over distance: explaining variation in state infrastructural power in Latin America. Harvard University.

Strange, S. (1996). The Retreat of the State: The Diffusion of Power in the World Economy. Cambridge University Press.

Straus, S. (2006). The order of genocide: Race, power, and war in Rwanda. Cambridge University Press.

Thies, C. G. (2005). War, rivalry, and state building in latin america. American Journal of Political Science, 49(3):451-465.

Thies, C. G. (2010). Of rulers, rebels, and revenue: State capacity, civil war onset, and primary commodities. Journal of Peace Research, 47(3):321-332.

Tilly, C. (1975). The formation of national states in europe. Princeton: Princeton University.

Tilly, C. (1992). Coercion, capital, and European states, AD 990-1992. WileyBlackwell.

Tilly, C. (2007). Democracy. Cambridge University Press.

Van de Walle, S. and Scott, Z. (2009). The role of public services in stateand nation building: Exploring lessons from european history for fragile states. Technical report, Governance and Social Development Resource Centre, University of Birmingham.

Vaughan, M. K. (1997). Cultural Politics in Revolution: Teachers, Peasants, and Schools in Mexico, 1930-1940. University of Arizona Press.

Weaver, R. K. and Rockman, B. A. (1993). Do institutions matter?: government capabilities in the United States and abroad. Brookings Institution Press. 
Weber, M. (1978). Economy and Society: An Outline of Interpretative Sociology. University of California Press.

Weiss, L. (1998). The myth of the powerless state. Cornell University Press.

Wildavsky, A. B. (1986). Budgeting: A Comparative Theory of Budgetary Processes. Transaction Publishers.

World Bank (1997). World development report 1997: the state in a changing world. World Bank Group.

Young, J. K. (2009). State capacity, democracy, and the violation of personal integrity rights. Journal of Human Rights, 8(4):283-300. 


\title{
Chapter 2
}

\section{Minding Weber more than ever? The impacts of State Capacity and Bureaucratic Autonomy on development goals}

\author{
Luciana Cingolani* \\ Kaj Thomsson ${ }^{\dagger}$ \\ Denis de Crombrugghe $e^{\ddagger}$
}

\begin{abstract}
The notion of state capacity has attracted renewed interest over the last few years, in particular in the study of violent conflict. Yet, state capacity is conceived differently depending on whether the interest lies in the state's power to discourage violent conflict, in its ability to administer efficiently, or simply in its capacity to foster economic development. In this article, we focus on bureaucratic autonomy as a distinct concept and discuss its connection to state capacity in detail. Using panel data over 1990-2010 and a novel indicator of bureaucratic autonomy, we then estimate the separate effect of state capacity and bureaucratic autonomy on two of the MDGs indicators: child mortality and tuberculosis prevalence. The evidence suggests that a) bureaucratic autonomy has a stronger impact than commonly used measures of state capacity; and b) bureaucratic autonomy plays a more important role for these indicators than traditional macroeconomic variables.
\end{abstract}

${ }^{*}$ Maastricht Graduate School of Governance - UNU-Merit. Corresponding author. Email: cingolani@merit.unu.edu.

${ }^{\dagger}$ Maastricht University, School of Business and Economics.

${ }^{\ddagger}$ Maastricht University, School of Business and Economics.

An earlier version of this article can be found as: Cingolani, Luciana, Kaj Thomsson and Denis de Crombrugghe (2013) "Minding Weber more than ever? The impacts of State Capacity and Bureaucratic Autonomy on development goals" UNU-Merit Working Paper 2013-052. United Nations University. 


\section{Introduction}

In the ongoing debate over the role of institutions in development, state capacity has emerged as a suggested catalyst of desirable social and economic outcomes. In this scholarly discussion, state capacity is portrayed as a potential source of strength that can fundamentally shape the implementation and final impact of policies, regardless of their ideological content and design.

The development of the state capacity concept has been shaped by the work of scholars from a wide array of disciplines and methodological approaches, seeking to understand both the effects of state capacity as well as its determinants. Unfortunately, the concept is poorly defined and has been stretched to a point where different scholars fill it with very different meanings ${ }^{1}$. As will be carefully explained later, an overview of the literature shows that scholars may implicitly or explicitly refer to at least four different dimensions of capacity: coercive, administrative, fiscal and/or legal capacity. In addition, normative and positive questions are often conflated. Furthermore, within the realm of normative questions, the view of the appropriate role of a (strong) state typically differs between studies of developed and developing countries. The following observation by Daron Acemoglu aptly captures some of this tension:

"While much research in political economy points out the benefits of 'limited government', political scientists have long emphasized the problems created in many less-developed nations by 'weak states', which lack the power to tax and regulate the economy and to withstand the political and social challenges from non-state actors" (Acemoglu 2005: 1199).

One of the key areas of contention and confusion around the state capacity concept concerns the role of "Weberian" bureaucratic attributes. These attributes are given central and almost defining roles in some of the research on state capacity, while they receive essentially no attention in other parts of the literature. In the first group we find influential work by scholars such as Evans (1995), Geddes (1996) and Evans and Rauch (1999), who focus on the organizational form of the state and view capacity as the consequence of efficient policy delegation to autonomous and professional bureaucratic bodies. In the second group, we find an eclectic group of scholars, including political scientists (Fearon 2005) and economists (Besley and Persson 2008, 2009), who

\footnotetext{
${ }^{1}$ See Hendrix (2010), Hanson and Sigman (2011) and Cingolani (2013) for a systematic analysis on the different dimensions and conceptualizations of state capacity.
} 
mostly link state capacity to conflict and the state's ability to centralize power and control the territory.

In this paper we aim to clear up some of this confusion by deepening our understanding of the relationship between bureaucratic autonomy and state capacity, with the ultimate goal of better understanding the role of autonomy and capacity in achieving fundamental social goals. More specifically, we aim to make the following contributions: first, to explore how traditional theories about bureaucracies fit within the more recent work on state capacity; second, to present a novel and objective indicator of bureaucratic autonomy that is comparable across time and space; and third, to estimate the impacts of both state capacity - in its multiple interpretations - and bureaucratic autonomy on (social) developmental goals. Along the way, we also survey the state capacity concept and show its versatility and multidimensionality.

The section that follows contains a historical overview of the different strands of the state capacity literature as well as the different measurements and definitions of the concept, with particular emphasis on the importance given to bureaucratic autonomy. In the third section, we empirically assess the associations between bureaucratic autonomy and state capacity, using several of the most commonly employed measures of state capacity and our novel indicator of bureaucratic autonomy. We show that the link between the two is non-trivial and nonlinear, and that it seems to be dependent on the political context, which justifies the inclusion of both in empirical analyses of the determinants of development goals. The fourth section contains the key empirical contributions of the paper. There, we examine the effects of both state capacity and bureaucratic autonomy on two policy indicators included in the Millennium Development Goals: child mortality rates and tuberculosis prevalence. We focus on these indicators because we view them as indisputable social goals that (essentially) everyone, across different regime types and ideological leanings, agrees with. We also find it plausible, ex ante, that the capacity of the state, for instance to distribute development aid effectively, could have a significant impact on the success rate of these goals. When we analyze the development of these indicators between 1990 and 2010, we find that bureaucratic autonomy has a stronger impact than state capacity, and that both bureaucratic autonomy and state capacity play a more important role for these indicators than traditional macroeconomic variables such as GDP growth. The fifth and final section contains preliminary conclusions and points that merit further discussion and analysis. 


\section{State capacities: where does the bureaucracy stand?}

Although the literature on state capacity gained special momentum over the recent years, its theoretical roots date back to the 'statist' movement of the seventies and eighties, illustrated by the salient works of Theda Skocpol, Charles Tilly, Peter Evans, Dieter Rueschemeyer, Alfred Stepan, among others. This movement responds to both Marxist and pluralist approaches portraying the state as a political arena colonized by a myriad of societal actors seeking personal gains. Statism, in contrast, argues that under certain conditions the state can credibly be independent from social classes and particularistic interests.

Following the Weberian tradition, this early political sociology literature systematized discussions on state capacity as something intrinsically linked to the quality of public bureaucracies. But as the concept 'traveled' to different disciplines and became more popular over time, the procedural and organizational aspects of the state became largely overlooked. Motivated by an interest in outcomes, more recent strands of literature focus on aspects such as the control of violence, the investment climate and/or countries' fiscal performance.

\subsection{The early interest in administrative capacity and auton- omy}

Several classic political sociology works stress the importance of bureaucracies for state capacity. Huntington (1968), for example, understands the strength of the state as the degree of institutionalization of its power. This institutionalization is determined by the level of adaptability, complexity, autonomy, coherence and coordination of the political organizations absorbing social transformations (1968: 12-23). In States and Social Revolutions (1979), Skocpol presents a comparative historical account of social revolutions in China, Russia and France, highlighting the importance of bureaucratic features in determining the opportunities for social change, and the subsequent path of evolution in state capacity. Along similar lines, Evans, Skocpol and Rueschemeyer's Bringing the State Back in (1985) gathers essays that explore the importance of autonomic power in the pursuit of different policy goals, such as sectoral industrial development, the management of economic crises, trade policy and conflict resolution, among others.

The comprehensive work of Mann $(1986,1993)$ The Sources of Social Power is also an illuminating exploration of the complexity surrounding the power of the state. Here, a distinction is made between despotic and infrastructural power: while the first refers to the state's capacity to impose legislation, the second 
looks at the actual operational capacity of the state within society, and the extent to which decisions at the political level can be implemented throughout the territory. The notion of infrastructural power permeated throughout the literature and led to numerous debates, in particular geared towards granting more importance to the street-level bureaucracy (see, for example, Soifer 2008 or Vom Hau and Soifer 2008).

In Embedded Autonomy (1995) Evans analyzes a series of causal mechanisms by which bureaucracies achieve the transformative capacity needed in order to shape structural change and promote industrial growth in newly-industrializing countries (NICs). Evans argues that the range of actions governments can take depends on the different kinds of state structures in place. He coined the term embedded autonomy, a combination of internal bureaucratic coherence within agencies and external connectedness with industrial sectors, which enables high-quality state intervention. Depending on the level of embedded autonomy, states come to be either predatory, intermediate or developmental, a classification extensively explored in Evans (1989) and further expanded in discussions on developmental and rentier states (e. g. Karl 1997, Kohli 2004).

Focusing on Latin American countries, Geddes (1996) asks which are the factors that determine politicians' decisions to appoint public managers on the basis of meritocratic principles, in contrast to partisan concerns. She defines state capacity as the implementation power of the state, a task that falls inherently under the bureaucracy. This power relies on the building of insulated public services, which in turn depends on the advancements towards meritoriented administrative reforms. In order to answer the initial question, she introduces the notion of the politician's dilemma: a president faces a tradeoff between appointing competent state managers who increase the chances of fostering growth and development, and appointing partisan managers to reassure their own support. Which path will be taken depends on a series of institutional and political conditions.

In the field of empirical macrodata, a key contribution was made by Evans and Rauch (1999), who provided a first systematic assessment of the links between bureaucracies and development. These scholars designed and built the Weberian State Dataset, a dataset made of surveys examining public service features such as meritocratic recruitment, salary arrangements and career paths in 35 developing (semi-industrialized) countries, with data representing the period 1970-1990. Their findings show strong associations between 'Weberianness' and economic growth. Also, Rauch and Evans (2000) find significant associations between bureaucratic 'Weberianness' and state effectiveness, measured with a number of different sources of data. 
More recently, the efforts in linking bureaucracies to discussions about state capacity and development have lost much of their initial momentum. While state capacity has acquired universality in its use by development scholars, the study of public service characteristics remains largely idiosyncratic, as it lacks comparability and empirical consensus regarding measurement. Among some notable exceptions, we find the scholarship making use of the Quality of Government survey on public administration, which seeks to measure to which extent administrations are impersonal in the implementation of their policies (Dahlström, Lapuente and Teorell 2010, among others); or occasional works on administrative capacity building (e. g. Christensen and Nielsen 2010). Other recent scholarship looks at public services across the world in ways unrelated to the concept of state capacity.

\subsection{Other notions of state capacity: coercive, fiscal and legal capacity}

As the concept of state capacity disseminated among different disciplines and debates, the focus was shifted towards a series of outcomes related to the coercive, fiscal and legal dimensions of capacity.

The importance of the state's coercive capacity to successfully control episodes of violence within its boundaries has been a core topic among recent studies on failed and weak states. Several works have explored the role of state capacity in conflict resolution in these settings. Fearon and Laitin (2003) show that among the factors that facilitate guerrilla warfare and insurgency are low financial, organizational, and political capacities of central governments. Similarly, DeRouen and Sobek (2004) find that state capacity is at the core of civil war outcomes and duration. Sobek (2010) shows that more capable states provide lesser opportunities for rebels to initiate violence, as they are able to channel social demands in a way that limits the possibilities of rebels to achieve collective action. Braithwaite (2010) contends that state capacity affects the probabilities of contagion from neighboring countries. DeRouen et. al. (2010), in turn, examine the importance of state capacity in the implementation of 14 peace agreements in Northern Island, Indonesia, Burundi, Mali and Somalia. They find that state capacity is indeed an important determinant of both the enactment and implementation of peace agreements.

Also, recent economic literature has developed an interest in understanding the incentives leaders face to invest in state capacity. Acemoglu, Ticchi and Vindigni (2006) use game theory to explain how inefficient states arise and persist. Here, state efficiency involves the abilities of a central authority to monitor bureaucrats, which in turn depends on previous investments in this 
capacity. Besley and Persson $(2008,2009)$ do extensive work on the determinants of capacity building as a type of investment under uncertainty. In Besley and Persson (2008) they analyze how self-interested incumbents invest part of today's government revenue in order to build fiscal capacities that secure higher extraction from society in the future. They show theoretically how two types of exogenous conflicts, internal insurgency and external war, affect the value that societies grant to public goods, and as a consequence, the relevance of investing in fiscal capacities. The model predicts that the expectation of future external conflict will raise today's investments in fiscal capacity, while the expectation of future internal conflict has the opposite effect. In an extended model, Besley and Persson (2009) also look at investments in legal capacity as an endogenous policy decision. Apart from conditioning investments on internal and external conflict, they also show that other political factors can change the value of public goods, such as the level of inclusiveness of institutions (capturing political polarization), the level of political stability, and whether the political regime resembles that of a utilitarian planner or a politically-controlled one. Several findings arise from their model: investments in legal and fiscal capacity are complementary; wealthier countries choose higher levels of both types of capacity; greater political stability raises investments in state capacity; a more representative political system (meaning, closer to the utilitarian planner ideal) also raises investments in both capacities; and finally, the higher the wealth of the ruling group, the higher the investments in legal capacity, and the lower in fiscal capacity.

Besley and Persson (2011) add a new component to their previous works: the reinforcing relationship between low state capacity and violence. Here, state capacity is defined as the "institutional capability of the state to carry out various policies that deliver benefits and services to households and firms" (Besley and Persson 2011: 6). The authors argue that a process of 'clusterization' occurs, where low income, low state capacity and high violence take place at the same time. The conclusions suggest that stable politics, along with consensual institutions and a higher demand for public goods are more conducive to greater investments in state capacities.

Dincecco and Katz (2012) present robust empirical evidence showing strong associations between extractive and productive state capacity and GDP per capita over a four-century period in 11 European nations. Dincecco and Prado (2012) confirm the effects of fiscal capacity on economic performance by instrumenting fiscal capacity with war casualties from 1816 to 1913 in various world regions. 


\subsection{State capacity: attributes in common}

This succinct overview covers the most influential works on the causes and effects of state capacity, allowing for a wide array of conceptual lenses. To sum up, the dimensions of state capacity that have attracted the greatest attention are the bureaucratic or administrative capacities to provide stable public goods through an autonomous bureaucracy; the coercive power to maintain order and prevent conflict; and the extractive or fiscal capacity of states to both centralize power and provide other socially-desirable public goods. A set of state capacity measurements is listed in the Appendix 6.1.

Two observations can be derived from the review. The first is that while the early literature defines with clarity the mechanisms by which Weberian autonomous bureaucracies lead to state capacity, these mechanisms are absent later on. Although recent scholarship typically assumes a strong role of the public service, it normally does no solve the tension between state capacity as a circumstantial increase in a government's political power (essential, for example, in coercive capacity) and an increase in the capabilities of the permanent bureaucracy (essential, for example, in legal capacity). Related to this, the second observation is that most definitions of state capacity refer to some sort of policy execution potential, and that this execution potential can come from different sources. It can certainly come from a professional and insulated bureaucracy, but (at least in the short term) it can also be attributed to high government revenue or strong leadership, which may or may not be associated with a particular organizational structure of the state.

Our work builds upon the existing literature in a number of ways. While we return to the earlier literature by emphasizing the role of (autonomous) bureaucracies, we attempt to move beyond it by developing a different type of autonomy measure, one which is objective and widely comparable over time and across countries. In addition, we focus on a different set of outcomes than previous contributions, and we use a variety of measures for state capacity, including many of the proxies used in recent work by economists. Hence, the work we present in the subsequent chapters may be viewed as a contribution to bridge the different strands of literature discussed above.

\section{Bureaucratic Autonomy and State Capacity: an empirical assessment of the association}

The theoretical exploration shows that state capacity encompasses multiple dimensions, and that certain strands of literature assume that bureaucratic 
autonomy is a component of state capacity, while others do not. As it becomes interesting to further unravel this relationship, this section goes one step forward by addressing the question: what is the empirical association between bureaucratic autonomy and the various measures of state capacity that scholars have presented?

For this purpose, we present correlations between state capacity and our proposed measure of bureaucratic autonomy, pooling historical data from between as early as 1960 and as late as 2010. Regarding the first, we replicate some of the most popular measures of state capacity used in the literature (see the list in Appendix 6.1). Regarding bureaucratic autonomy, our proposed original measure is explained in the next subsection. Although the notion of bureaucratic autonomy involves substantial complexity in itself, the way it is conceived here follows the Weberian and Wilsonian traditions of relative separation between politics and administration ${ }^{2}$, and is broadly defined as the $d e$ facto non-alignment of political cycles and the cycles of autonomous bureaucracies. However relevant, bureaucratic autonomy from private interest groups is not considered at this point. We describe both bureaucratic autonomy and state capacity measures in Table 1.

\footnotetext{
${ }^{2}$ See for example, Weber (1978 Vol. II); Wilson (1897 in Arthur 1966); Goodnow (2003).
} 
Table 1: Bureaucratic Autonomy and State Capacity: Data description

\begin{tabular}{|c|c|c|c|c|c|c|c|}
\hline Variable & Description & Source & Countries (Years) & Mean & St. Dev & Min & $\operatorname{Max}$ \\
\hline $\begin{array}{l}\text { Bureaucratic } \\
\text { Autonomy }\end{array}$ & $\begin{array}{l}\text { Measures the level of } \\
\text { politicization of bureaucratic } \\
\text { appointments, based on data } \\
\text { from central banks. }\end{array}$ & $\begin{array}{l}\text { Own compilation based } \\
\text { on Dreher, Sturm and } \\
\text { deHaan }(2010)\end{array}$ & $95(1970-2010)$ & -0.381 & 0.420 & -0.928 & 0.833 \\
\hline $\begin{array}{l}\text { Control of } \\
\text { Corruption }\end{array}$ & $\begin{array}{l}\text { Experts' perception of } \\
\text { corruption in both the } \\
\text { private and public sectors. }\end{array}$ & $\begin{array}{l}\text { International Country } \\
\text { Risk Guide (ICRG) }\end{array}$ & 143 (1984-2010) & 2.14 & 1.18 & 0 & 4 \\
\hline $\begin{array}{l}\text { Control of } \\
\text { Corruption }\end{array}$ & $\begin{array}{l}\text { Levels of corruption based on } \\
\text { data from TI. }\end{array}$ & $\begin{array}{l}\text { Heritage Foundation } \\
\text { and TI }\end{array}$ & $163(1994-2006)$ & 40.26 & 26.43 & 0 & 100 \\
\hline CPI & $\begin{array}{l}\text { Corruption Perception Index } \\
\text { from experts' assessments. }\end{array}$ & $\begin{array}{l}\text { Transparency } \\
\text { International }\end{array}$ & $181(1995-2010)$ & 4.31 & 2.27 & 0.4 & 10 \\
\hline Property Rights & $\begin{array}{l}\text { Measures the legal protection } \\
\text { of property rights, risk of } \\
\text { expropriation and contract } \\
\text { compliance. }\end{array}$ & Heritage Foundation & $163(1994-2006)$ & 50.61 & 23.81 & 10 & 90 \\
\hline Rule of Law & $\begin{array}{l}\text { Measures levels of compliance } \\
\text { with the law. }\end{array}$ & $\begin{array}{l}\text { World Bank } \\
\text { Governance Indicators }\end{array}$ & 194 (1996-2009) & -0.75 & 0.99 & -2.68 & 2.12 \\
\hline $\begin{array}{l}\text { Contract } \\
\text { Intensive Money }\end{array}$ & $\begin{array}{l}\text { Proportion of the money } \\
\text { supply held in the banking } \\
\text { system (M2-M1/M2). }\end{array}$ & $\begin{array}{l}\text { World Development } \\
\text { Indicators (WDI) }\end{array}$ & $179(1960-2010)$ & 0.474 & 1.322 & -96.296 & 0.970 \\
\hline $\begin{array}{l}\text { Government } \\
\text { Revenue }\end{array}$ & $\begin{array}{l}\text { Government revenue as share } \\
\text { of GDP. }\end{array}$ & $\begin{array}{l}\text { World Development } \\
\text { Indicators (WDI) }\end{array}$ & $146(1990-2010)$ & 25.35 & 10.72 & 0.334 & 65.26 \\
\hline Income Tax II & $\begin{array}{l}\text { Taxes on income, profits and } \\
\text { capital gains as share of total } \\
\text { taxes. }\end{array}$ & $\begin{array}{l}\text { World Development } \\
\text { Indicators }\end{array}$ & $146(1990-2010)$ & 34.11 & 16.81 & 0.575 & 100 \\
\hline Income Tax & $\begin{array}{l}\text { Taxes on income, profits and } \\
\text { capital gains as share of total } \\
\text { revenue. }\end{array}$ & $\begin{array}{l}\text { World Development } \\
\text { Indicators (WDI) }\end{array}$ & $145(1990-2010)$ & 21.92 & 12.76 & 0.013 & 66.715 \\
\hline Fiscal Capacity I & 1 - Share of Trade tax. & $\begin{array}{l}\text { World Development } \\
\text { Indicators (WDI) }\end{array}$ & $138(1990-2010)$ & 0.878 & 0.130 & 0.353 & 1.162 \\
\hline Fiscal Capacity II & $\begin{array}{l}1-(\text { Share of income tax }+ \\
\text { Share of trade tax }) .\end{array}$ & $\begin{array}{l}\text { World Development } \\
\text { Indicators (WDI) }\end{array}$ & $136(1990-2010)$ & 0.67 & 0.162 & 0.227 & 0.983 \\
\hline $\begin{array}{l}\text { Fiscal Capacity } \\
\text { III }\end{array}$ & $\begin{array}{l}\text { Share of income tax } * \text { Share } \\
\text { of government revenue. }\end{array}$ & $\begin{array}{l}\text { World Development } \\
\text { Indicators (WDI) }\end{array}$ & $141(1990-2010)$ & 0.057 & 0.043 & 0.0005 & 0.28 \\
\hline $\begin{array}{l}\text { Fiscal Capacity } \\
\text { IV }\end{array}$ & Tax revenue as share of GDP. & $\begin{array}{l}\text { World Development } \\
\text { Indicators (WDI). }\end{array}$ & $146(1990-2010)$ & 0.166 & 0.074 & 0.0008 & 0.589 \\
\hline $\begin{array}{l}\text { Primary } \\
\text { Commodity } \\
\text { Exports }\end{array}$ & $\begin{array}{l}\text { Sum of food, fuel, } \\
\text { agricultural and ores exports } \\
\text { as share of total merchandise } \\
\text { exports. }\end{array}$ & $\begin{array}{l}\text { World Development } \\
\text { Indicators (WDI) }\end{array}$ & $182(1962-2010)$ & 60.76 & 37.28 & 1.308 & 821.852 \\
\hline Tax from exports & $\begin{array}{l}\text { Total exports as share of } \\
\text { GDP. }\end{array}$ & $\begin{array}{l}\text { World Development } \\
\text { Indicators (WDI) }\end{array}$ & $181(1960-2010)$ & 34.154 & 22.743 & 0.183 & 243.436 \\
\hline $\begin{array}{l}\text { Military } \\
\text { Personnel }\end{array}$ & $\begin{array}{l}\text { Military personnel in } \\
\text { thousands. }\end{array}$ & $\begin{array}{l}\text { Correlates of War } \\
(\mathrm{COW})\end{array}$ & 197 (1946-2007) & 169.048 & 522.99 & 0 & 12500 \\
\hline $\begin{array}{l}\text { Military } \\
\text { Expenditure }\end{array}$ & $\begin{array}{l}\text { Ln of Military Expenditure } \\
\text { in constant US dollars. }\end{array}$ & $\begin{array}{l}\text { Correlates of War } \\
(\mathrm{COW})\end{array}$ & 197 (1946-2007) & 12.187 & 2.477 & 3.367 & 20.13 \\
\hline State Fragility & State Fragility Index. & Polity 4 & $163(1995-2010)$ & 9.823 & 6.692 & 0 & 25 \\
\hline Inflation & $\begin{array}{l}\text { Inflation, consumer prices } \\
\text { (annual \%). }\end{array}$ & $\begin{array}{l}\text { World Development } \\
\text { Indicators (WDI) }\end{array}$ & 177 (1961-2010) & 30.417 & 383.051 & -21.675 & 23773.13 \\
\hline Road Density & $\begin{array}{l}\text { Km of road per } 100 \text { sq. } \mathrm{km} \text { of } \\
\text { land area. }\end{array}$ & $\begin{array}{l}\text { World Development } \\
\text { Indicators (WDI) }\end{array}$ & $179(2001-2009)$ & 111.157 & 328.222 & 0 & 3850 \\
\hline $\begin{array}{l}\text { Military in } \\
\text { Politics }\end{array}$ & $\begin{array}{l}\text { Experts perception on the } \\
\text { military participation in } \\
\text { government. }\end{array}$ & $\begin{array}{l}\text { International Country } \\
\text { Risk Guide (ICRG) }\end{array}$ & $143(1984-2010)$ & 3.718 & 1.82 & 0 & 6 \\
\hline GDP per capita & $\begin{array}{l}\text { Log of GDP per Capita, PPP } \\
\text { (Constant International } \\
\text { USD). }\end{array}$ & $\begin{array}{l}\text { World Development } \\
\text { Indicators (WDI) }\end{array}$ & $178(1980-2008)$ & 8.417 & 1.273 & 5.016 & 11.466 \\
\hline
\end{tabular}

\subsection{Measuring Bureaucratic Autonomy}

Finding adequate measures of civil service characteristics that are deep in time and comparable across countries has been a long standing and rather unsuccessful challenge, as pointed out by Fukuyama (2012, 2013).

A number of projects have systematically studied national bureaucracies. As 
mentioned earlier, one of the first is the Weberianness Survey by the University of California San Diego (Evans and Rauch 1999). This survey comprised 35 emerging economies and collected data with time-invariant values representing the period 1970-1990. Although country scores were based on interviews with key stakeholders, the questions sought to uncover objective patterns in the public administration in three main areas: meritocratic recruitment, career paths and salary schemes.

Also, the PRS group commercializes data on bureaucratic quality as part of the International Country Risk Guide (ICRG), which exists for a large number of countries since 1984. The index is based on experts' assessments and published on a yearly basis. Although criticized for its lack of transparency (e.g. Fukuyama 2012), ICRG's index of Bureaucratic Quality has been used to measure state capacity in articles particularly interested in administrative features of the state.

In 2005, the World Bank started to publish their IDA Resource Allocation Index (IRAI), based on data from the Country Policy and Institutional Assessment (CPIA). CPIA data assigns scores to 77 countries in 16 different policy and institutional items, divided in four areas: economic management, structural policies, policies for social inclusion and equity, and public sector management and institutions. Within the latter, there is one particular item measuring the quality of public administration. It defines six different levels of quality, based on policy coordination and responsiveness, implementation efficiency, merit and ethics, and payment schemes.

Another interesting source of data on the bureaucracy comes from the Global Integrity Index (GII) by the NGO Global Integrity. This index started in 2004 and has assessed 109 countries on different aspects of governance (although with high variance in the number of waves for each country and their regularity). In particular, the indicator Civil Service: Conflicts of Interest Safeguards and Political Independence computes experts' appraisal of the legal measures in place to protect the civil service from politicization.

More recently, the Quality of Government Institute launched a web survey meant to capture the impartiality of the public service in 58 countries, with insights from 528 country experts (Dahlström, Lapuente and Teorell 2010). It comprises questions assessing the degree of politicization and favoritism in the implementation of policies.

These indicators suffer from a series of limitations: lack of time variation and limited coverage of countries (Evans and Rauch 1999; Dahlström, Lapuente and Teorell 2010), very short panels (CPIA, GII), non-systematic coverage of countries (GII), lack of full clarity in the scoring criteria (CPIA and ICRG), 
lack of objective measurements (as opposed to perception-based), which is the case of all of the above mentioned sources. Other authors have undertaken important efforts to measure agency independence, but data are only crosssectional (Gilardi and Maggetti 2010; Hanretty and Koop 2009), comprise only 16 European countries (Gilardi and Maggetti 2010) or the full dataset is unavailable for public use (Hanretty and Koop 2009). Additionally, the concept of bureaucratic autonomy entails a level of complexity that has made it difficult to find consensus regarding its operationalization (Christensen 2010).

We are therefore left with no objective indicators for bureaucratic autonomy with time series variation, and are forced to look for proxy variables instead. After careful consideration of various literatures on bureaucratic capacity and autonomy, we choose to use objective data on the politicization of removals of central bank governors, in countries where central banks enjoy formal autonomy and fixed mandates for their head executives. We gather these data simply by computing whether removals occur before the governor's legal mandate is due, which allows to capture a more general de facto correlation between political and bureaucratic cycles in the areas in which the bureaucracy is expected to be autonomous.

We resort to one of the many variables included in the comprehensive database compiled by Dreher, Sturm and de Haan (2010), which informs whether central bank governor turnovers are regular or irregular, in 158 territorial units (countries and banking unions) over the period 1970-2011. This regularity is defined in relation to their legal mandate, where rotations occurring before the legal date are considered irregular. Regular turnovers (RegTOR) are recorded by one binary variable $(\operatorname{RegTOR}=1)$, irregular turnovers by another (Irreg$\mathrm{TOR}=1$ ). On this basis, we propose the following measure of bureaucratic autonomy:

$$
A U T_{i t}=\frac{\sum_{s=1}^{t} \operatorname{Reg} T O R_{i s}-\sum_{s=1}^{t} \operatorname{Irreg}_{\mathrm{T}} \mathrm{R}_{i s}}{1+\sum_{s=1}^{t} \operatorname{Reg} T O R_{i s}+\sum_{s=1}^{t} \operatorname{IrregTOR}_{i s}}
$$

$A U T_{i t}$ measures the annual cumulative ratio of irregular to regular turnovers over the preceding 20-year period, arising from data from as early as 1970 . It has a rather straightforward interpretation: negative measures indicate that most of the turnovers (TOR) have been irregular and positives indicate the opposite. We consider here that a higher proportion of regular turnovers means a more autonomous life for the agency. By resorting to a de facto measure, the indicator does not necessarily pick up the effect of legal reforms (except indirectly through changes in legal mandates $)^{3}$.

\footnotetext{
${ }^{3}$ Data for this indicator is available as supplementary material. The index covers 93
} 
The assumption that central bank autonomy is representative of overall bureaucratic autonomy is critical. Basically, in the current state of the art, this is a data constraint. Although we have attempted to gather data on various (more or less autonomous) state agencies for many countries and years, so far have found only comprehensive data for central banks. However, we believe our assumption is supported by previous theoretical work. For instance, Gilardi's extensive work on how to operationalize agency autonomy (2002, 2005a, 2008) is directly inspired by the literature on central bank independence and the aim of extending a similar approach to other agencies (Gilardi and Maggetti 2010: 3-4).

We also find support for our choice in the work of North, Wallis, Weingast and Webb, where courts and central banks are regarded as key areas that should maintain their autonomy from rulers: "In a mature LAO [limitedaccess order], the government's commitments to policies and institutions can be more credible [than in fragile or basic LAOs] because elite private organizations are in a position to put economic pressure on the government to abide by its commitments. This ability arises as private organizations act to protect their interests in the differentiation and autonomy of public institutions, such as courts and the central bank" (North, Wallis, Weingast and Webb 2011: 18$19)$.

In addition, the scatterplots of Appendix 6.4 show positive and significant correlations between our proxy of bureaucratic autonomy and several alternative measures of bureaucratic independence and quality.

\subsection{Data and analysis}

Once we have laid out our novel and objective indicator of bureaucratic autonomy, and selected a number of indices of state capacity from the literature, we run a series of correlations.

Table 1 describes the variables and presents descriptive statistics for the data used in the analysis. Table 2 presents panel bivariate correlations between our Bureaucratic Autonomy Index $\left(A U T_{i t}\right)$ and commonly used operationalizations of state capacity. In order to test the possibility of context-dependence in the relationship between state capacity and bureaucratic autonomy, the full sample of observations is divided into autocracies, anocracies and democracies. A country in a given year is an autocracy if the index Polity2 from the database PolityIV is less than -5 ; anocracies are between -5 and 5 and

countries, well balanced across world regions (see Appendix 6.2), and shows rather similar values across regime types (see Appendix 6.3). 
democracies are those above 5 (Marshall and Jaggers 2013). At first glance, the correlations show that there is no clearly positive or negative correlation between the two. However, an interesting exploratory pattern seems to arise from the correlations: state capacity is positively correlated with autonomy in most of the cases within the sub-sample of democracies, while there is a less clear pattern for anocracies and autocracies.

Table 2: Bivariate Correlations: Bureaucratic Autonomy and State Capacity

\begin{tabular}{lllll}
\hline \hline Dimension & SC measure & Autocracies & Anocracies & Democracies \\
\hline Administrative & Bureaucratic Quality & -0.008 & -0.111 & $0.279^{* *}$ \\
& Control of corruption (ICRG) & -0.022 & -0.037 & $0.169^{*}$ \\
& Control of corruption (HF) & 0.120 & -0.070 & 0.180 \\
Legal & CPI & 0.104 & $-0.339^{* * *}$ & 0.180 \\
& Property Rights & 0.118 & -0.018 & 0.119 \\
& Rule of Law & -0.079 & -0.098 & 0.124 \\
& Contract intensive money & $-0.195^{* *}$ & 0.093 & 0.083 \\
& Government Revenue & 0.151 & -0.214 & 0.072 \\
& Income Tax & -0.007 & 0.074 & 0.230 \\
& Income Tax II & -0.141 & 0.017 & 0.227 \\
& Fiscal capacity I & $-0.428^{* * *}$ & 0.007 & 0.061 \\
& Fiscal capacity II & -0.112 & -0.002 & $-0.246^{*}$ \\
& Fiscal Capacity III & -0.010 & -0.128 & 0.201 \\
& Fiscal Capacity IV & -0.108 & $-0.297^{*}$ & 0.055 \\
& Primary commodity exports $\left(\mathrm{R}^{*}\right)$ & 0.145 & 0.137 & -0.157 \\
Coercive & Tax from exports & 0.196 & -0.019 & -0.045 \\
& Military Personnel & $-0.180^{* * *}$ & $-0.101^{*}$ & -0.044 \\
& Log of Military Expend & $-0.216^{* *}$ & $-0.270^{* *}$ & $0.195^{*}$ \\
Others & State Fragility (R ${ }^{*}$ (Pol4) & 0.166 & 0.142 & -0.042 \\
& Inflation (R*) & 0.000 & -0.038 & $-0.044^{* *}$ \\
& Road Density & -0.169 & 0.005 & -0.001 \\
& Military in Politics & 0.006 & 0.198 & 0.148 \\
& GDPpc (log) & -0.180 & -0.012 & 0.189 \\
\hline \hline
\end{tabular}

Notes: $\mathrm{R}^{*}$ indicates a reversed scale, meaning that higher values of the variable represent less capacity. Stars indicate significance levels: ${ }^{*} p<0.10$, ${ }^{* *}$ $p<0.05,{ }^{* * *} p<0.01$. These levels are adjusted by the clustering within countries.

A cautious interpretation of this could be that the indicator captures the true level of autonomy better in democratic settings, and that in the case of autocracies and anocracies the measurement is less reliable. Another interpretation is that while bureaucratic autonomy and state capacity tend to converge in the context of democracies, they behave independently in anocracies and autocracies. In these types of polities, it is apparent that capacity, if anything, is coming from sources other than bureaucratic autonomy. In any case, the correlations suggest that the relationship between state capacity and bureaucratic 
autonomy is not homogeneous and that it should be interpreted in the context of the different regimes' characteristics. This basic evidence can in principle sustain and reconcile the different links between bureaucratic autonomy and state capacity observed in the literature: bureaucratic autonomy is a credible component of state capacity in certain conditions, but not always.

\section{The Impacts of Bureaucratic Autonomy and State Capacity on the MDGs}

This section's purpose is to move beyond conceptual considerations and test whether both state capacity and bureaucratic autonomy levels have significant impacts on a series of policy goals. So far, research has provided evidence of the positive and significant impact of state capacity on economic performance (Evans and Rauch 1999, Dincecco and Katz 2012; Dincecco and Prado 2012; Hamm, King and Stuckler 2012) and peace (Sobek 2010; Braithwaite 2010). Here, it is the goal to empirically estimate and compare the effects of state capacity and bureaucratic autonomy on two indicators of the Millennium Development Goals: child mortality and tuberculosis prevalence rates. As mentioned in the introduction, we focus on these indicators because we view them as sensible social outcomes that are likely to be indisputable as social goals across (essentially) every country and regime type. We also find it plausible, ex ante, that the capacity of the state, for instance to distribute development aid effectively, to accumulate expertise and human resources, or to grant stability to policy implementation mechanisms, could have a significant impact on whether a country is successful in achieving these goals.

There have been numerous statistical studies assessing the determinants of child mortality and tuberculosis levels. The work of Wang (2003) uses Demographic and Health Survey data (DHS) to unravel the factors that affect infant and child mortality in 60 low-income countries. Among other findings, the work shows that urbanization determines a faster reduction in mortality, as well as access to electricity, income levels, children's vaccination in their first year, and health expenditure. Gakidou et al. (2010) use time series data for 175 countries to tackle a similar question. They assemble a comprehensive database on educational attainment and find that increases in the years of education of women in reproductive age (between 15 and 44) substantially reduce child mortality levels on a year-to-year basis between 1970 and 2009. In addition to the traditional health factors, Leipziger et al. (2003) also find an important role played by access to basic infrastructure, such as access to piped water and improved sanitation. Liu et. al. (2012) account for the most recent 
trends in child mortality, showing a global decrease of more than $25 \%$ in the ten years from 2000 to 2010. Its findings show that neonatal complications and infectious diseases such as pneumonia, diarrhea, and malaria explain a substantial proportion of the primary causes of child mortality.

Regarding tuberculosis, Dye et al. (2009) find that higher scores in the Human Development Index (HDI), lower levels of child mortality, and proper access to improved sanitation accelerate the decrease in tuberculosis incidence, although this rate varies substantially in different world regions. In a comprehensive review of six empirical studies, Lönnroth et al. (2010) conclude that a clear log-linear relationship exists between Body Mass Indexes (BMI) and the incidence of tuberculosis. The work of Hargreaves et al. (2011) focuses on the social determinants of tuberculosis, and develops a framework based on data from the Commission on Social Determinants of Health (CSDH) and WHO that suggests that social protection mechanisms, as well as effective urban planning interventions should be considered in analyzing progress in tuberculosis control.

We build on all of this previous work on the determinants of child mortality and tuberculosis levels. However, our primary focus here is on the role of political and government aspects, as a lot less is known about how these affect the MDGs. One notable exception is the United Nations Economic and Social Commission for Asia and the Pacific (UNESCAP) report of 2007, centered around the role of governance in the provision of basic services to the poor. It stresses the importance of good governance in overcoming barriers to access, and argues that certain principles such as inclusiveness, transparency and civic participation facilitate the achievement of MDGs (UNESCAP 2007). The analysis also contributes to discussions about the role of Weberianness in poverty reduction more generally (e.g. Henderson et al. 2007).

We therefore contribute to the discussion on the determinants of the two MDGs, child mortality and tuberculosis levels by placing the focus on bureaucratic autonomy and state capacity. Our estimations measure the effect of a series of policy, institutional and economic variables on the evolution of child mortality and tuberculosis prevalence. The selection of determinants is informed by previous studies on the subject. The estimation equations with all covariates are:

$$
\begin{aligned}
\text { CHmort }_{i, t} & =\alpha+\beta_{1} \mathrm{AUT}_{i, t}+\beta_{2} \mathrm{CAP}_{i, t}+\beta_{3} \mathrm{DEM}_{i, t}+\beta_{4} \mathrm{GDPpc}_{i, t-1}+\beta_{5} \mathrm{GROWTH}_{i, t-1} \\
& +\beta_{6} \mathrm{POPGr}_{i, t}+\beta_{7} \mathrm{ATTAIN}_{i, t-1}+\beta_{8} \mathrm{URB}_{i, t-1}+\beta_{9} \mathrm{IMMUN}_{i, t-1}+\beta_{11} \mathrm{WATER}_{i, t-1}+ \\
& \beta_{12} \mathrm{SFI}_{i, t}+\beta_{13} \mathrm{HEALTH}_{i, t-1}+\beta_{14} \mathrm{SOC}_{i, t-1}+\beta_{15} \mathrm{EDUC}_{i, t-1}+u_{i}+\epsilon_{i, t}
\end{aligned}
$$


and similarly:

$$
\begin{aligned}
\text { TBprev }_{i, t} & =\alpha+\beta_{1} \mathrm{AUT}_{i, t}+\beta_{2} \mathrm{CAP}_{i, t}+\beta_{3} \mathrm{DEM}_{i, t}+\beta_{4} \mathrm{GDPpc}_{i, t-1}+\beta_{5} \mathrm{GROWTH}_{i, t-1} \\
& +\beta_{6} \mathrm{POPGr}_{i, t}+\beta_{7} \operatorname{ATTAIN}_{i, t-1}+\beta_{8} \mathrm{URB}_{i, t-1}+\beta_{9} \mathrm{IMMUN}_{i, t-1}+\beta_{11} \mathrm{WATER}_{i, t-1}+ \\
& \beta_{12} \mathrm{SFI}_{i, t}+\beta_{13} \mathrm{HEALTH}_{i, t-1}+\beta_{14} \mathrm{SOC}_{i, t-1}+\beta_{15} \mathrm{EDUC}_{i, t-1}+u_{i}+\epsilon_{i, t}
\end{aligned}
$$

Tables 3 and 4 provide an empirical assessment of the relationships formulated in eqs. (2) and (3) respectively. The first dependent variable (CHmort) is the annual mortality rate among children under 5 (per 1,000) taken from the World Development Indicators of the World Bank ${ }^{4}$. The second dependent variable (TBprev) is the annual level of tuberculosis prevalence (per 100,000 people) also taken from $\mathrm{WDI}^{5}$. Both tables include three types of specifications: a basic set of general determinants (specifications 1 and 4), a more extended set of determinants (2 and 5), and a model with all covariates (3 and 6), as expressed in eqs. (2) and (3).

The baseline specification includes general institutional and economic determinants. The first explanatory variable is our Bureaucratic Autonomy Index (AUT) as presented in eq. (1). The second is a measure of state capacity (CAP): yearly levels of tax revenue as share of GDP, taken from the Government Finance Statistics (GFS-IMF) ${ }^{6}$. Although there are several proxies for state capacity, this is one of the most widely used and accepted. A continuous measure of democracy levels is included (DEM), taken from the Polity2 indicator of the Polity IV project updated to 2011. The lags of per capita GDP (GDPpc) and GDP growth (GROWTH) are collected from the New Angus Maddison database.

The second specification adds demographic and infrastructural determinants, following the bulk of the literature on child mortality and tuberculosis: a) a measure of population growth (annual \%) taken from WDI (POPgr); b) the lag of educational attainment levels of women in reproductive age (1544) (ATTAIN), with data from Gakidou et al. (2010) and complemented with

\footnotetext{
${ }^{4}$ Under-five mortality rate is the probability per 1,000 that a newborn baby will die before reaching age five, if subject to current age-specific mortality rates. Data on child mortality as well as tuberculosis prevalence are downloaded from the World Bank Open Database (Azevedo 2011).

${ }^{5}$ The prevalence of tuberculosis is the estimated number of pulmonary, smear positive, and extra-pulmonary tuberculosis cases (WHO 2011).

${ }^{6}$ GFS has two bases of measurement for all their variables: cash and non-cash (i. e. disbursements versus commitments). Countries have tended to shift from cash to non-cash (accrual) accountancy systems, and although both are considered in order to maximize the number of observations, a small non-systematic bias arises during transitions. The non-cash basis is preferred when both measures are available.
} 
Barro and Lee (forthcoming) for the year 2010; c) the lag of urbanization rates (URB), understood as the share of the population living in urban areas; d) the lag of access to safe water (WATER), and finally e) we construct a measure of immunization levels (IMMUN), averaging the share of one-year-old children immunized against hepatitis B, BCG and Polio. These three measures are taken from the World Bank Open Database (Azevedo 2011).

The extended specifications further include three policy measures showing sectoral government expenditures: the lags of health (HEALTH), education (EDUC) and social protection (SOC) expenditure as a share of GDP, from GFS $(\mathrm{IMF})^{7}$; as well as a State Fragility Index (SFI) from Polity IV $^{8}$ (only available since 1995) in order to control for conflicts or other shocks that might drag changes in the levels of bureaucratic autonomy. Section 6.5 in the Appendix shows descriptive statistics for all the variables in the estimations.

Data are cross-national time-series for the period 1990-2010 (unbalanced), and estimations are run with both random (RE) and fixed effects (FE) in order to capture unobservable time-invariant determinants $\left(u_{i}\right)$. Standardized 'beta' coefficients are reported, with corresponding p-values in parentheses (rather than standard errors or t-statistics). Tables 3 and 4 also report the number of observations, the overall $R^{2}$, and for the RE specifications also the p-value of the Hausman specification test in order to assess the suitability of RE vs. FE assumptions.

\subsection{Results}

The six specifications of Table 3 show somewhat similar results in terms of the explanatory variables' effects on child mortality. The Hausman test, however, suggests that while the random effects model is acceptable for the baseline column (1), only the fixed effects model should be considered for the more complete specifications. Column 1 displays a negative and highly significant association between all explanatory variables and child mortality, with the exception of GDP growth. In Column 4 the coefficients and significance levels remain very similar. Column 5 shows again a highly significant and inverse relationship between bureaucratic autonomy and child mortality, while the significance of state capacity (tax revenue) is diminished. Democracy does not exert an effect anymore. Of the two macroeconomic variables, GDP per capita and GDP growth, only GDP per capita is significantly associated to lower

\footnotetext{
${ }^{7}$ The same criterion is applied as in the Tax Revenue variable.

${ }^{8} \mathrm{SFI}$ combines scores on eight dimensions of stateness, ranging from 0 (no fragility) to 25 (extreme fragility): security, political, economic and social a) legitimacy and b) effectiveness (Marshall and Jaggers 2013).
} 
levels of child mortality. The more popular determinants of child mortality such as female educational attainment, urbanization, immunization and safe water access show a significant inverse effect. Population growth, on the other hand, exerts no effect. When the specification is extended in column 6 , all variables retain their sign and significance, with the exception of GDP per capita and state capacity, which become insignificant, albeit after a substantial loss in observations. Of the policy variables only health expenditure appears as significant, although with a positive sign. This may be indicating a case of reverse causation, by which health expenditure effectively responds to child mortality levels. The explanatory power of the estimations is high, ranging from $65 \%$ to $73 \%$ of the variance being explained.

Table 4 estimates the effect of the same set of determinants on TB prevalence. In this case the Hausman test suggests that both RE and FE are consistent estimators for the baseline ( 1 and 4 ) and extended models (columns 3 and 6 ), while RE is rejected in Column 2. Columns 1 and 4 report a significant negative association between bureaucratic autonomy and TB prevalence, and a significant positive association between the latter and state capacity. There is also a strong negative impact of GDP per capita. The FE estimator in Column 5 shows similar results for the previous three variables. Immunization and safe water access levels also exert a significant impact in the expected direction, although female education emerges as moderately significant with a positive sign. In the extended specifications (3 and 6) bureaucratic autonomy, state capacity and GDP per capita maintain their sign and significance. Immunization levels show again a strong negative impact, while female education loses overall significance. Social protection and education expenditure emerge as weakly significant with a positive sign, suggesting again a potential case of reverse causality. The overall $R^{2}$ fluctuate between 24 and $34 \%$ when explaining the variance of TB prevalence. To address potential multicollinearity concerns among the determinants, we run collinearity diagnostics and provide a correlation matrix of all variables in the Appendix $6.6^{9}$.

In sum, the overall results in both Tables 3 and 4 suggest that higher bureaucratic autonomy is strongly associated with reductions in child mortality and TB prevalence levels over the 1990-2010 period, while the effect of state capacity is more ambiguous. The results also reinforce the impacts of the traditional demographic and infrastructural determinants found in the literature, in par-

\footnotetext{
${ }^{9}$ The diagnostics shows that a Variance Inflation Factor higher than 30 is found only for three economic variables: immunization, access to safe water and lnGDP per capita. Because these have low standard errors they continue to show significance in spite of the high VIF. The diagnostics for the baseline specification variables show low collinearity, with a VIF lower than 9, meaning that the key explanatory variables bureaucratic autonomy and state capacity remain stable, while the explanatory power of the model remains high.
} 
ticular immunization and access to safe water levels. All three policy variables appear as somewhat relevant for these development outcomes, although the nature of the association needs to be more carefully assessed.

These results confirm the importance of autonomous bureaucratic institutions in improving basic welfare standards. When comparing the effects of organizational aspects of state capacity (autonomy) with fiscal ones, it can be cautiously claimed that the former have a stronger effect for the period examined.

To further test this last premise, Tables 5 and 6 test the extended model against alternative measures of state capacity, in the administrative, legal and coercive dimensions, for the same time period and sample of countries. In these, bureaucratic autonomy emerges as significant at the $1 \%$ level in five out of the six specifications, for both MDG outcome variables. The different state capacity alternatives have negative and significant effects on child mortality as well in four out of the six columns. For TB prevalence, on the other hand, the evidence concerning the effect of state capacity is rather ambiguous.

\section{Conclusions}

In this article we have assessed the relationship between state capacities, bureaucratic autonomy and two socio-economic development goals. We started by discussing the theoretical links between state capacity and bureaucratic autonomy. In this discussion, we highlighted that much of the early work on 'state effectiveness' or 'state capacity' presupposes the existence of professional and politically insulated Weberian bureaucracies, while other strands of related research - mainly work concerned with conflict and development - pay little or no explicit attention to bureaucratic capacity or bureaucratic autonomy.

With this scholarly divide in mind, we developed a strategy for better understanding the empirical links between state capacity and bureaucratic autonomy. We proposed a novel and minimalist indicator of bureaucratic autonomy, and we assessed the links between this indicator and the most commonly used measures of state capacity. The results show that the nature of the relationship depends on the political context. More specifically, the association between bureaucratic autonomy and state capacity is positive in democracies but ambiguous in autocracies and anocracies. This suggests that state capacity and bureaucratic autonomy, as we have defined these concepts, only partially overlap and should be analyzed separately in empirical studies. 
Table 3: Determinants of MDGs: Child mortality (unbalanced sample)

\begin{tabular}{|c|c|c|c|c|c|c|}
\hline \multirow[t]{2}{*}{ Dep var: Child mortality } & \multicolumn{3}{|c|}{$\overline{\mathrm{RE}}$} & \multicolumn{3}{|c|}{$\mathrm{FE}$} \\
\hline & (1) & $(2)$ & $(3)$ & $(4)$ & $(5)$ & $(6)$ \\
\hline Bureaucratic Autonomy & $\begin{array}{c}-0.059^{* * *} \\
(0.001)\end{array}$ & $\begin{array}{c}-0.043^{* * *} \\
(0.003)\end{array}$ & $\begin{array}{c}-0.031^{* *} \\
(0.021)\end{array}$ & $\begin{array}{c}-0.066^{* * *} \\
(0.000)\end{array}$ & $\begin{array}{c}-0.046^{* * *} \\
(0.002)\end{array}$ & $\begin{array}{c}-0.035^{* * *} \\
(0.008)\end{array}$ \\
\hline Tax Revenue (\% GDP) & $\begin{array}{c}-0.052^{* * *} \\
(0.008)\end{array}$ & $\begin{array}{c}-0.032^{* *} \\
(0.039)\end{array}$ & $\begin{array}{c}-0.024 \\
(0.113)\end{array}$ & $\begin{array}{c}-0.059^{* * *} \\
(0.004)\end{array}$ & $\begin{array}{c}-0.027^{*} \\
(0.090)\end{array}$ & $\begin{array}{l}-0.013 \\
(0.412)\end{array}$ \\
\hline Democracy & $\begin{array}{c}-0.088^{* * *} \\
(0.000)\end{array}$ & $\begin{array}{l}0.004 \\
(0.751)\end{array}$ & $\begin{array}{c}-0.025^{* *} \\
(0.037)\end{array}$ & $\begin{array}{c}-0.092^{* * *} \\
(0.000)\end{array}$ & $\begin{array}{r}0.010 \\
(0.467)\end{array}$ & $\begin{array}{l}-0.018 \\
(0.136)\end{array}$ \\
\hline Ln GDP per capita (lag) & $\begin{array}{c}-0.834^{\text {*** }} \\
(0.000)\end{array}$ & $\begin{array}{c}-0.185^{* * *} \\
(0.000)\end{array}$ & $\begin{array}{r}-0.041 \\
(0.323)\end{array}$ & $\begin{array}{c}-0.830^{* * *} \\
(0.000)\end{array}$ & $\begin{array}{c}-0.165^{* * *} \\
(0.000)\end{array}$ & $\begin{array}{l}-0.016 \\
(0.708)\end{array}$ \\
\hline GDP growth (lag) & $\begin{array}{l}0.006 \\
(0.424)\end{array}$ & $\begin{array}{l}0.010^{*} \\
(0.098)\end{array}$ & $\begin{array}{l}0.001 \\
(0.895)\end{array}$ & $\begin{array}{c}0.005 \\
(0.468)\end{array}$ & $\begin{array}{l}0.009 \\
(0.116)\end{array}$ & $\begin{array}{l}-0.001 \\
(0.910)\end{array}$ \\
\hline Population growth & & $\begin{array}{l}0.011 \\
(0.434)\end{array}$ & $\begin{array}{l}0.005 \\
(0.756)\end{array}$ & & $\begin{array}{l}0.001 \\
(0.926)\end{array}$ & $\begin{array}{r}-0.009 \\
(0.633)\end{array}$ \\
\hline Female educ attainment (lag) & & $\begin{array}{c}-0.375^{* * *} \\
(0.000)\end{array}$ & $\begin{array}{c}-0.402^{* * *} \\
(0.000)\end{array}$ & & $\begin{array}{c}-0.355^{* * *} \\
(0.000)\end{array}$ & $\begin{array}{c}-0.412^{* * *} \\
(0.000)\end{array}$ \\
\hline Urbanization (lag) & & $\begin{array}{c}-0.212^{* * *} \\
(0.000)\end{array}$ & $\begin{array}{c}-0.348^{* * *} \\
(0.000)\end{array}$ & & $\begin{array}{c}-0.395^{* * *} \\
(0.000)\end{array}$ & $\begin{array}{c}-0.584^{* * *} \\
(0.000)\end{array}$ \\
\hline Immunization (lag) & & $\begin{array}{c}-0.050^{* * *} \\
(0.000)\end{array}$ & $\begin{array}{c}-0.020^{* *} \\
(0.028)\end{array}$ & & $\begin{array}{c}-0.046^{* * *} \\
(0.000)\end{array}$ & $\begin{array}{c}-0.021^{* *} \\
(0.020)\end{array}$ \\
\hline Safe water access (lag) & & $\begin{array}{c}-0.328^{* * *} \\
(0.000)\end{array}$ & $\begin{array}{c}-0.291^{* * *} \\
(0.000)\end{array}$ & & $\begin{array}{c}-0.302^{* * *} \\
(0.000)\end{array}$ & $\begin{array}{c}-0.249^{* * *} \\
(0.000)\end{array}$ \\
\hline State Fragility Index & & & $\begin{array}{c}0.071^{* *} \\
(0.019)\end{array}$ & & & $\begin{array}{l}0.060^{*} \\
(0.052)\end{array}$ \\
\hline Health expenditure (lag) & & & $\begin{array}{c}0.033^{* * *} \\
(0.001)\end{array}$ & & & $\begin{array}{c}0.033^{* * *} \\
(0.001)\end{array}$ \\
\hline Social Protection expenditure (lag) & & & $\begin{array}{l}-0.005 \\
(0.743)\end{array}$ & & & $\begin{array}{l}-0.004 \\
(0.783)\end{array}$ \\
\hline Education expenditure (lag) & & & $\begin{array}{l}-0.003 \\
(0.855)\end{array}$ & & & $\begin{array}{l}-0.014 \\
(0.320)\end{array}$ \\
\hline Observations & 1101 & 1005 & 593 & 1101 & 1005 & 593 \\
\hline$R^{2}$ (overall) & 0.654 & 0.754 & 0.734 & 0.651 & 0.726 & 0.688 \\
\hline Hausman p-value & 0.245 & 0.022 & 0.000 & & & \\
\hline
\end{tabular}

Standardized beta coefficients; $p$-values in parentheses.

${ }^{*} p<0.10,{ }^{* *} p<0.05,{ }^{* * *} p<0.01$ 
Table 4: Determinants of MDGs: Tuberculosis prevalence (unbalanced sample)

\begin{tabular}{|c|c|c|c|c|c|c|}
\hline \multirow[t]{2}{*}{ Dep var: TB prevalence } & \multicolumn{3}{|c|}{$\mathrm{RE}$} & \multicolumn{3}{|c|}{$\mathrm{FE}$} \\
\hline & (1) & $(2)$ & $(3)$ & (4) & (5) & (6) \\
\hline \multirow{2}{*}{ Bureaucratic Autonomy } & $-0.037^{*}$ & $-0.042^{*}$ & $-0.069^{* * *}$ & $-0.045^{* *}$ & $-0.051^{* *}$ & $-0.078^{* * *}$ \\
\hline & $(0.072)$ & $(0.057)$ & $(0.003)$ & $(0.035)$ & $(0.025)$ & $(0.001)$ \\
\hline \multirow[t]{2}{*}{ Tax Revenue (\% GDP) } & $0.086^{* * *}$ & $0.110^{* * *}$ & $0.090^{* * *}$ & $0.084^{* * *}$ & $0.110^{* * *}$ & $0.087^{* * *}$ \\
\hline & $(0.000)$ & $(0.000)$ & $(0.000)$ & $(0.000)$ & $(0.000)$ & $(0.001)$ \\
\hline \multirow[t]{2}{*}{ Democracy } & -0.019 & -0.008 & -0.018 & -0.022 & -0.013 & -0.022 \\
\hline & $(0.328)$ & $(0.674)$ & $(0.382)$ & $(0.272)$ & $(0.540)$ & $(0.294)$ \\
\hline \multirow[t]{2}{*}{ Ln GDP per capita (lag) } & $-0.501^{* * *}$ & $-0.473^{* * *}$ & $-0.360^{* * *}$ & $-0.481^{* * *}$ & $-0.494^{* * *}$ & $-0.343^{* * *}$ \\
\hline & $(0.000)$ & $(0.000)$ & $(0.000)$ & $(0.000)$ & $(0.000)$ & $(0.000)$ \\
\hline \multirow[t]{2}{*}{ GDP growth (lag) } & -0.004 & 0.001 & 0.002 & -0.005 & 0.002 & 0.002 \\
\hline & $(0.611)$ & $(0.882)$ & $(0.815)$ & $(0.553)$ & $(0.849)$ & $(0.839)$ \\
\hline \multirow{2}{*}{ Population growth } & & 0.018 & 0.007 & & 0.020 & 0.004 \\
\hline & & $(0.394)$ & $(0.828)$ & & $(0.367)$ & $(0.893)$ \\
\hline \multirow[t]{2}{*}{ Female educ attainment (lag) } & & $0.140^{* *}$ & $0.137^{*}$ & & $0.175^{* *}$ & 0.128 \\
\hline & & $(0.030)$ & $(0.087)$ & & $(0.025)$ & $(0.169)$ \\
\hline \multirow[t]{2}{*}{ Urbanization (lag) } & & -0.107 & -0.149 & & -0.086 & -0.013 \\
\hline & & $(0.202)$ & $(0.144)$ & & $(0.487)$ & $(0.934)$ \\
\hline \multirow[t]{2}{*}{ Immunization (lag) } & & $-0.062^{* * *}$ & $-0.098^{* * *}$ & & $-0.061^{* * *}$ & $-0.097^{* * *}$ \\
\hline & & $(0.000)$ & $(0.000)$ & & $(0.000)$ & $(0.000)$ \\
\hline \multirow[t]{2}{*}{ Safe water access (lag) } & & $-0.136^{* * *}$ & -0.073 & & $-0.153^{* * *}$ & -0.080 \\
\hline & & $(0.000)$ & $(0.000)$ & & $(0.000)$ & $(0.000)$ \\
\hline \multirow[t]{2}{*}{ State Fragility Index } & & & -0.033 & & & -0.037 \\
\hline & & & $(0.531)$ & & & $(0.494)$ \\
\hline \multirow[t]{2}{*}{ Health expenditure (lag) } & & & -0.008 & & & -0.009 \\
\hline & & & $(0.664)$ & & & $(0.629)$ \\
\hline \multirow[t]{2}{*}{ Social Protection expenditure (lag) } & & & $0.043^{*}$ & & & $0.046^{*}$ \\
\hline & & & $(0.081)$ & & & $(0.066)$ \\
\hline \multirow[t]{2}{*}{ Education expenditure (lag) } & & & $0.053^{* *}$ & & & $0.059^{* *}$ \\
\hline & & & $(0.024)$ & & & $(0.017)$ \\
\hline Observations & 1101 & 1005 & 593 & 1101 & 1005 & 593 \\
\hline$R^{2}$ (overall) & 0.323 & 0.344 & 0.303 & 0.321 & 0.333 & 0.247 \\
\hline Hausman p-value & 0.572 & 0.000 & 0.469 & & & \\
\hline
\end{tabular}

\footnotetext{
Standardized beta coefficients; $p$-values in parentheses.

${ }^{*} p<0.10,{ }^{* *} p<0.05,{ }^{* * *} p<0.01$
} 
Table 5: Determinants of Child Mortality: different dimensions of State Capacity

\begin{tabular}{|c|c|c|c|c|c|c|}
\hline & 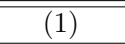 & 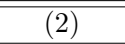 & 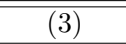 & $\overline{(4)}$ & 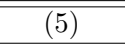 & 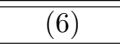 \\
\hline Bureaucratic Autonomy & $\begin{array}{l}-0.014 \\
(0.256)\end{array}$ & $\begin{array}{c}-0.058^{* * *} \\
(0.000)\end{array}$ & $\begin{array}{c}-0.038^{* *} \\
(0.011)\end{array}$ & $\begin{array}{c}-0.048^{* * *} \\
(0.001)\end{array}$ & $\begin{array}{c}-0.041^{* * *} \\
(0.001)\end{array}$ & $\begin{array}{c}-0.041^{* * *} \\
(0.002)\end{array}$ \\
\hline Bureaucratic Quality & $\begin{array}{c}-0.037^{* * *} \\
(0.005)\end{array}$ & & & & & \\
\hline Freedom from Corruption & & $\begin{array}{c}-0.034^{* * *} \\
(0.004)\end{array}$ & & & & \\
\hline Contract Intensive Money & & & $\begin{array}{l}0.017 \\
(0.194)\end{array}$ & & & \\
\hline Property Rights & & & & $\begin{array}{c}0.024^{*} \\
(0.091)\end{array}$ & & \\
\hline Military expenditure (log) & & & & & $\begin{array}{c}-0.080^{* * *} \\
(0.000)\end{array}$ & \\
\hline Military Personnel & & & & & & $\begin{array}{c}-0.095^{* *} \\
(0.037)\end{array}$ \\
\hline Democracy & $\begin{array}{c}-0.023^{*} \\
(0.063)\end{array}$ & $\begin{array}{l}0.002 \\
(0.894)\end{array}$ & $\begin{array}{l}-0.003 \\
(0.824)\end{array}$ & $\begin{array}{l}0.002 \\
(0.881)\end{array}$ & $\begin{array}{l}-0.006 \\
(0.624)\end{array}$ & $\begin{array}{l}-0.002 \\
(0.891)\end{array}$ \\
\hline Ln GDP per capita (lag) & $\begin{array}{l}0.017 \\
(0.695)\end{array}$ & $\begin{array}{l}0.006 \\
(0.897)\end{array}$ & $\begin{array}{r}-0.018 \\
(0.679)\end{array}$ & $\begin{array}{l}-0.057 \\
(0.260)\end{array}$ & $\begin{array}{l}0.014 \\
(0.767)\end{array}$ & $\begin{array}{l}-0.047 \\
(0.313)\end{array}$ \\
\hline GDP growth (lag) & $\begin{array}{l}-0.000 \\
(0.958)\end{array}$ & $\begin{array}{l}0.004 \\
(0.393)\end{array}$ & $\begin{array}{l}0.000 \\
(0.934)\end{array}$ & $\begin{array}{l}0.005 \\
(0.284)\end{array}$ & $\begin{array}{l}0.005 \\
(0.354)\end{array}$ & $\begin{array}{c}0.003 \\
(0.559)\end{array}$ \\
\hline Population growth & $\begin{array}{l}-0.010 \\
(0.566)\end{array}$ & $\begin{array}{l}-0.019 \\
(0.176)\end{array}$ & $\begin{array}{l}-0.012 \\
(0.491)\end{array}$ & $\begin{array}{r}-0.014 \\
(0.307)\end{array}$ & $\begin{array}{l}-0.012 \\
(0.436)\end{array}$ & $\begin{array}{l}-0.012 \\
(0.440)\end{array}$ \\
\hline Female educ attainment (lag) & $\begin{array}{c}-0.396^{* * *} \\
(0.000)\end{array}$ & $\begin{array}{c}-0.377^{* * *} \\
(0.000)\end{array}$ & $\begin{array}{c}-0.374^{* * *} \\
(0.000)\end{array}$ & $\begin{array}{c}-0.311^{\text {*** }} \\
(0.000)\end{array}$ & $\begin{array}{c}-0.366^{* * *} \\
(0.000)\end{array}$ & $\begin{array}{c}-0.332^{* * *} \\
(0.000)\end{array}$ \\
\hline Urbanization (lag) & $\begin{array}{c}-0.597^{* * *} \\
(0.000)\end{array}$ & $\begin{array}{c}-0.579^{* * *} \\
(0.000)\end{array}$ & $\begin{array}{c}-0.683^{* * *} \\
(0.000)\end{array}$ & $\begin{array}{c}-0.627^{* * *} \\
(0.000)\end{array}$ & $\begin{array}{c}-0.620^{* * *} \\
(0.000)\end{array}$ & $\begin{array}{c}-0.707^{* * *} \\
(0.000)\end{array}$ \\
\hline Immunization (lag) & $\begin{array}{c}-0.019^{* *} \\
(0.024)\end{array}$ & $\begin{array}{l}0.007 \\
(0.442)\end{array}$ & $\begin{array}{r}-0.014^{*} \\
(0.086)\end{array}$ & $\begin{array}{l}0.007 \\
(0.438)\end{array}$ & $\begin{array}{l}-0.006 \\
(0.506)\end{array}$ & $\begin{array}{l}-0.004 \\
(0.675)\end{array}$ \\
\hline Safe water access (lag) & $\begin{array}{c}-0.218^{* * *} \\
(0.000)\end{array}$ & $\begin{array}{c}-0.276^{* * *} \\
(0.000)\end{array}$ & $\begin{array}{c}-0.236^{* * *} \\
(0.000)\end{array}$ & $\begin{array}{c}-0.263^{* * *} \\
(0.000)\end{array}$ & $\begin{array}{c}-0.267^{* * *} \\
(0.000)\end{array}$ & $\begin{array}{c}-0.272^{* * *} \\
(0.000)\end{array}$ \\
\hline State Fragility Index & $\begin{array}{c}0.088^{* * *} \\
(0.003)\end{array}$ & $\begin{array}{c}0.087^{* * *} \\
(0.003)\end{array}$ & $\begin{array}{c}0.075^{* *} \\
(0.014)\end{array}$ & $\begin{array}{c}0.070^{* *} \\
(0.020)\end{array}$ & $\begin{array}{c}0.076^{* * *} \\
(0.009)\end{array}$ & $\begin{array}{c}0.074^{* *} \\
(0.012)\end{array}$ \\
\hline Health expenditure (lag) & $\begin{array}{c}0.027^{* * *} \\
(0.006)\end{array}$ & $\begin{array}{c}0.033^{* * *} \\
(0.001)\end{array}$ & $\begin{array}{c}0.031^{* * *} \\
(0.002)\end{array}$ & $\begin{array}{c}0.035^{* * *} \\
(0.001)\end{array}$ & $\begin{array}{c}0.037^{* * *} \\
(0.000)\end{array}$ & $\begin{array}{c}0.035^{* * *} \\
(0.000)\end{array}$ \\
\hline Social Protection expenditure (lag) & $\begin{array}{l}-0.022 \\
(0.125)\end{array}$ & $\begin{array}{c}-0.028^{* *} \\
(0.045)\end{array}$ & $\begin{array}{l}-0.015 \\
(0.316)\end{array}$ & $\begin{array}{c}-0.030^{* *} \\
(0.034)\end{array}$ & $\begin{array}{c}-0.027^{*} \\
(0.055)\end{array}$ & $\begin{array}{c}-0.023^{*} \\
(0.100)\end{array}$ \\
\hline Education expenditure (lag) & $\begin{array}{r}-0.008 \\
(0.579)\end{array}$ & $\begin{array}{l}-0.006 \\
(0.706)\end{array}$ & $\begin{array}{l}-0.010 \\
(0.492)\end{array}$ & $\begin{array}{r}-0.003 \\
(0.819)\end{array}$ & $\begin{array}{l}-0.004 \\
(0.750)\end{array}$ & $\begin{array}{l}-0.003 \\
(0.804)\end{array}$ \\
\hline Observations & 537 & 505 & 558 & 505 & 549 & 549 \\
\hline$R^{2}$ (overall) & 0.733 & 0.695 & 0.695 & 0.691 & 0.705 & 0.698 \\
\hline
\end{tabular}

Fixed effects estimations. Standardized beta coefficients; $p$-values in parentheses.

${ }^{*} p<0.10,{ }^{* *} p<0.05,{ }^{* * *} p<0.01$ 
Table 6: Determinants of Tuberculosis Prevalence: different dimensions of State Capacity

\begin{tabular}{|c|c|c|c|c|c|c|}
\hline & (1) & $(2)$ & $(3)$ & (4) & $(5)$ & (6) \\
\hline Bureaucratic Autonomy & $\begin{array}{c}-0.077^{* * *} \\
(0.001)\end{array}$ & $\begin{array}{c}-0.081^{* * *} \\
(0.002)\end{array}$ & $\begin{array}{c}-0.079^{* * *} \\
(0.003)\end{array}$ & $\begin{array}{l}-0.037 \\
(0.151)\end{array}$ & $\begin{array}{c}-0.072^{\text {*** }} \\
(0.003)\end{array}$ & $\begin{array}{c}-0.072^{* * *} \\
(0.003)\end{array}$ \\
\hline Bureaucratic Quality & $\begin{array}{c}-0.155^{* * *} \\
(0.000)\end{array}$ & & & & & \\
\hline Freedom from Corruption & & $\begin{array}{c}-0.031 \\
(0.160)\end{array}$ & & & & \\
\hline Contract Intensive Money & & & $\begin{array}{c}0.052^{* *} \\
(0.024)\end{array}$ & & & \\
\hline Property Rights & & & & $\begin{array}{c}0.156^{* * *} \\
(0.000)\end{array}$ & & \\
\hline Military expenditure (log) & & & & & $\begin{array}{l}0.047 \\
(0.220)\end{array}$ & \\
\hline Military Personnel & & & & & & $\begin{array}{c}0.016 \\
(0.849)\end{array}$ \\
\hline Democracy & $\begin{array}{l}-0.012 \\
(0.608)\end{array}$ & $\begin{array}{l}-0.000 \\
(1.000)\end{array}$ & $\begin{array}{l}-0.013 \\
(0.525)\end{array}$ & $\begin{array}{l}-0.008 \\
(0.733)\end{array}$ & $\begin{array}{l}-0.005 \\
(0.825)\end{array}$ & $\begin{array}{l}-0.007 \\
(0.752)\end{array}$ \\
\hline Ln GDP per capita (lag) & $\begin{array}{c}-0.270^{* * *} \\
(0.001)\end{array}$ & $\begin{array}{c}-0.237^{* *} \\
(0.014)\end{array}$ & $\begin{array}{c}-0.282^{* * *} \\
(0.000)\end{array}$ & $\begin{array}{c}-0.439^{* * *} \\
(0.000)\end{array}$ & $\begin{array}{c}-0.303^{* * *} \\
(0.001)\end{array}$ & $\begin{array}{c}-0.277^{* * *} \\
(0.002)\end{array}$ \\
\hline GDP growth (lag) & $\begin{array}{l}0.001 \\
(0.882)\end{array}$ & $\begin{array}{c}0.004 \\
(0.679)\end{array}$ & $\begin{array}{c}0.004 \\
(0.689)\end{array}$ & $\begin{array}{l}0.008 \\
(0.377)\end{array}$ & $\begin{array}{c}0.002 \\
(0.845)\end{array}$ & $\begin{array}{c}0.003 \\
(0.741)\end{array}$ \\
\hline Population growth & $\begin{array}{l}0.003 \\
(0.934)\end{array}$ & $\begin{array}{l}-0.005 \\
(0.844)\end{array}$ & $\begin{array}{l}0.009 \\
(0.784)\end{array}$ & $\begin{array}{l}0.005 \\
(0.851)\end{array}$ & $\begin{array}{l}0.000 \\
(0.995)\end{array}$ & $\begin{array}{l}0.000 \\
(0.991)\end{array}$ \\
\hline Female educ attainment (lag) & $\begin{array}{l}0.072 \\
(0.479)\end{array}$ & $\begin{array}{l}0.114 \\
(0.310)\end{array}$ & $\begin{array}{l}0.145 \\
(0.139)\end{array}$ & $\begin{array}{c}0.406^{* * *} \\
(0.000)\end{array}$ & $\begin{array}{l}0.117 \\
(0.236)\end{array}$ & $\begin{array}{l}0.109 \\
(0.285)\end{array}$ \\
\hline Urbanization (lag) & $\begin{array}{l}0.090 \\
(0.545)\end{array}$ & $\begin{array}{l}-0.035 \\
(0.846)\end{array}$ & $\begin{array}{l}0.027 \\
(0.856)\end{array}$ & $\begin{array}{l}-0.134 \\
(0.435)\end{array}$ & $\begin{array}{l}0.036 \\
(0.821)\end{array}$ & $\begin{array}{c}0.063 \\
(0.704)\end{array}$ \\
\hline Immunization (lag) & $\begin{array}{c}-0.079^{* * *} \\
(0.000)\end{array}$ & $\begin{array}{c}-0.041^{* *} \\
(0.013)\end{array}$ & $\begin{array}{c}-0.072^{* * *} \\
(0.000)\end{array}$ & $\begin{array}{c}-0.039^{* *} \\
(0.015)\end{array}$ & $\begin{array}{c}-0.058^{* * *} \\
(0.000)\end{array}$ & $\begin{array}{c}-0.058^{* * *} \\
(0.000)\end{array}$ \\
\hline Safe water access (lag) & $\begin{array}{c}-0.129^{* *} \\
(0.031)\end{array}$ & $\begin{array}{r}-0.047 \\
(0.531)\end{array}$ & $\begin{array}{l}-0.086 \\
(0.141)\end{array}$ & $\begin{array}{l}-0.055 \\
(0.434)\end{array}$ & $\begin{array}{r}-0.066 \\
(0.310)\end{array}$ & $\begin{array}{l}-0.070 \\
(0.292)\end{array}$ \\
\hline State Fragility Index & $\begin{array}{l}-0.021 \\
(0.711)\end{array}$ & $\begin{array}{l}0.077 \\
(0.179)\end{array}$ & $\begin{array}{l}0.007 \\
(0.902)\end{array}$ & $\begin{array}{c}0.011 \\
(0.837)\end{array}$ & $\begin{array}{l}0.034 \\
(0.536)\end{array}$ & $\begin{array}{c}0.034 \\
(0.533)\end{array}$ \\
\hline Health expenditure (lag) & $\begin{array}{l}-0.006 \\
(0.731)\end{array}$ & $\begin{array}{l}-0.003 \\
(0.888)\end{array}$ & $\begin{array}{l}-0.006 \\
(0.754)\end{array}$ & $\begin{array}{l}-0.007 \\
(0.718)\end{array}$ & $\begin{array}{l}-0.005 \\
(0.778)\end{array}$ & $\begin{array}{c}-0.004 \\
(0.840)\end{array}$ \\
\hline Social Protection expenditure (lag) & $\begin{array}{l}0.051^{*} \\
(0.067)\end{array}$ & $\begin{array}{l}0.024 \\
(0.386)\end{array}$ & $\begin{array}{l}0.039 \\
(0.137)\end{array}$ & $\begin{array}{l}0.022 \\
(0.411)\end{array}$ & $\begin{array}{l}0.037 \\
(0.167)\end{array}$ & $\begin{array}{c}0.034 \\
(0.199)\end{array}$ \\
\hline Education expenditure (lag) & $\begin{array}{c}0.061^{* *} \\
(0.025)\end{array}$ & $\begin{array}{c}0.056^{* *} \\
(0.048)\end{array}$ & $\begin{array}{c}0.058^{* *} \\
(0.023)\end{array}$ & $\begin{array}{c}0.058^{* *} \\
(0.035) \\
\end{array}$ & $\begin{array}{c}0.062^{* *} \\
(0.018) \\
\end{array}$ & $\begin{array}{c}0.061^{* *} \\
(0.019) \\
\end{array}$ \\
\hline $\begin{array}{l}\text { Observations } \\
R^{2} \text { (overall) }\end{array}$ & $\begin{array}{c}537 \\
0.219 \\
\end{array}$ & $\begin{array}{c}505 \\
0.110 \\
\end{array}$ & $\begin{array}{c}558 \\
0.159 \\
\end{array}$ & $\begin{array}{c}505 \\
0.177\end{array}$ & $\begin{array}{c}549 \\
0.128 \\
\end{array}$ & $\begin{array}{c}549 \\
0.125 \\
\end{array}$ \\
\hline
\end{tabular}

Fixed effects estimations. Standardized beta coefficients; $p$-values in parentheses.

${ }^{*} p<0.10,{ }^{* *} p<0.05,{ }^{* * *} p<0.01$ 
Building on this insight, we estimated the separate effects of state capacity and bureaucratic autonomy on child mortality rates and the prevalence of tuberculosis, two of the indicators from the Millennium Development Goals. The results indicate that autonomy is effective in explaining the improvements that have taken place with respect to these two goals over the past two decades. There is also some evidence that the level of fiscal state capacity, proxied by government tax revenue, has explanatory power when it comes to changes in child mortality, though in the case of tuberculosis the results are difficult to interpret, even seemingly counterintuitive, and therefore deserve further exploration. Other institutional determinants, such as the nature of the political regime, appear less relevant. In contrast to what may be expected, GDP growth does not appear clearly associated to the achievement of either MDG goal, although in the case of tuberculosis prevalence, the GDP per capita level is. Traditional health and infrastructural variables are systematically significant.

These results suggest that state capacity and bureaucratic autonomy deserve an important place in discussions about the links between institutions and (social and economic) development. The finding that more autonomous civil services are associated with faster gains in health standards, even when accounting for some degree of heterogeneity at the country level, should prompt policymakers to better endow bureaucratic cadres and minimize short-termist influences.

Yet, many important questions, both theoretical and empirical, remain open. The contextual dependence of the convergence (or lack thereof) between state capacity and bureaucratic autonomy, discussed in Section 3, reminds us that institutional development is not a smooth and easily predicted process, and much work remains before we have a satisfactory understanding of the causal links between autonomy, capacity and institutional change (or institutional persistence). Among other things, future work should seek additional objective measures of bureaucratic autonomy that incorporate other agencies than central banks. Future work should also extend the analysis and improve the precision of the relationships we have estimated in this paper, not only by collecting more data of similar nature but also by complementing quantitative data with in-depth, qualitative studies of bureaucratic structures and institutional evolution. 


\section{Acknowledgements}

We are grateful to Nicolas Meisel, Thomas Roca, Eddy Szirmai, Fransizka Gassmann, Bo Rothstein, Carl Dahlström, Marina Nistotskaya, Marcia Grimes, Michelle D'Arcy, Jörg Faust, Luis Camacho and Armin von Schiller for insightful comments and suggestions, as well as participants at the SASE general conference held in Milan, June 2013; the Développement, Institutions \& Mondialisation conference in Paris, June 2013, the ECPR general conference in Bordeaux, September 2013, and seminars at the Quality of Government Institute and the German Development Institute in Bonn. Thanks in particular to three anonymous reviewers for their helpful comments and suggestions. 


\section{Appendix}

\subsection{Measures of state capacity in the literature}

\begin{tabular}{|c|c|c|}
\hline Measurements of state capacity & Source & $\begin{array}{c}\text { Dimension of state capacity } \\
\text { emphazised }\end{array}$ \\
\hline $\begin{array}{l}\text { Weberianness' of the state: Weberian State Dataset, measuring meritocratic } \\
\text { recruitment, salary arrangements and career paths. }\end{array}$ & $\begin{array}{l}\text { Authors' elaboration: Weberianess } \\
\text { Survey (UCSD) }\end{array}$ & Bureaucratic / administrative \\
\hline Date of first national census. & Goyer et. Al. (1983) & Infrastructural / generic \\
\hline Railroad density in 1900. & Mitchell (1983) & Infrastructural / generic \\
\hline Statehist5: index of state antiquity. & Authors' elaboration. & Generic \\
\hline Log of GDP per capita. & & Generic \\
\hline Bureucractic Quality and Control of Corruption. & ICRG-PRS Group. & Bureaucratic / administrative \\
\hline $\begin{array}{l}\text { National capabilities regarding national revenue and expenditures in Western } \\
\text { Europe. }\end{array}$ & E.g.: Mann (1993) and Straus (2006) & Bureaucratic / administrative \\
\hline Territorial variation in the ability of the state to compel compliance. & $\begin{array}{l}\text { E.g.: Kalyvas (2006), Goodwin (2001) } \\
\text { and Soifer (2006). }\end{array}$ & Territorial control \\
\hline Effects of state policy on social identity. & E.g.: Weber (1976) and Vaughan (1997). & Relational capacity \\
\hline Private credit to GDP ratio. & King and Levine (1993) & Legal \\
\hline Access to credit (rank). & \multirow{2}{*}{ Doing Business } & Legal \\
\hline Investor protection (rank). & & Legal \\
\hline Index of government anti-diversion policies (sum of five different indicators). & ICRG-PRS Group. & Legal \\
\hline One minus the share of trade taxes in total taxes. & \multirow{4}{*}{ IMF / WDI } & Fiscal / Extractive \\
\hline One minus the share of trade and indirect taxes in total taxes. & & Fiscal / Extractive \\
\hline Share of income taxes in GDP. & & Fiscal / Extractive \\
\hline Share of taxes in GDP. & & Fiscal / Extractive \\
\hline Quality of Public Goods Provision consists of a five item index (for Europe): & & \\
\hline Levels of corruption. & CPI-TI, Heritage Foundation & Bureaucratic / administrative \\
\hline Quality of property rights protection. & Heritage Foundation & Legal \\
\hline Taxing capacity: Ratio of tax revenue to GDP. & IMF & Fiscal / Extractive \\
\hline Progress in infrastructure reform, infrastructure indicators. & EBRD & Infrastructural \\
\hline $\begin{array}{l}\text { Ratio of noncurrency money to total money supply (ratio of currency to money } \\
\text { held in banks). }\end{array}$ & IMF complemented with EIU & Legal \\
\hline Total revenue / GDP; total tax/GDP; relative political capacity. & Johnson and Rabinowitz (2005) & Fiscal / Extractive \\
\hline Relative political capacity: actual tax revenue / expected tax revenue. & Kugler and Arbetman (1997) & Fiscal / Extractive \\
\hline GDP share of total revenue. & \multirow{3}{*}{$\begin{array}{l}\text { Baunsgaard and Keen (2010) from GFS } \\
\text { and IMF country documents. }\end{array}$} & Fiscal capacity \\
\hline GDP share of income tax revenues. & & Fiscal capacity \\
\hline Total tax share of domestic tax revenue. & & Fiscal capacity \\
\hline Index of "outright confiscation and forced natinalization". & ICRG-PRS Group & Bureaucratic / administrative \\
\hline Ease of doing business. & Doing Business & Bureaucratic / administrative \\
\hline Government effectiveness. & WGI & Bureaucratic / administrative \\
\hline Columbia State Capacity Survey question 21. & Columbia University & Bureaucratic / administrative \\
\hline State Capabilities measure. & IADB (Berkman et. Al. 2008). & Bureaucratic / administrative \\
\hline Bureaucratic quality & PRS - ICRG & Bureaucratic / administrative \\
\hline Census frequency & UN Statistics & Territorial control \\
\hline Proportion of Contract Intensive Money (CIM) & WDI online & Legal \\
\hline Road density & International Roads Federation - WDI & Infrastructural \\
\hline State Antiquity Index & Bockstette et. Al. (2002) & Generic \\
\hline Rule of law & PRS - ICRG & Legal \\
\hline Total tax revenue & IMF-WDI & Fiscal / Extractive \\
\hline Income tax revenue & IMF - WDI & Fiscal / Extractive \\
\hline Tax revenue from goods and services & IMF-WDI & Fiscal / Extractive \\
\hline Taxes on international trade & IMF-WDI & Fiscal / Extractive \\
\hline Military personnel per capita. & $\begin{array}{l}\text { Correlates of War (CoW), National } \\
\text { Material Capabilities v.3.02 }\end{array}$ & Coercive \\
\hline Military spending (as \% of Government Expenditures) & CoW and CNTS & Coercive \\
\hline Military in politics & PRS - ICRG & Coercive \\
\hline State Fragility index. & Polity IV & Coercive \\
\hline Legal capacity: index of protection of property rights in 1997 (ICRG data). & ICRG-PRS Group. & Legal \\
\hline Fiscal capacity: total taxes as share of GDP in 1999 (IMF data). & IMF & Fiscal \\
\hline $\begin{array}{l}\text { Changes in total government spending between } 1992 \text { and } 2000 \text { (government } \\
\text { spending in } 2000 \text { U. S. dollars expressed as the share of } 1992 \text { spending). }\end{array}$ & WDI & Fiscal / Extractive \\
\hline $\begin{array}{l}\text { Survey questions capturing firm managers' perceptions on state efficiency, } \\
\text { property rights compliance and corruption levels. }\end{array}$ & $\begin{array}{l}\text { EBRD Business Environment and } \\
\text { Enterprise Performance Surveys. }\end{array}$ & Generic \\
\hline Government revenue (1650-1913) and government spending (1816-1913). & Data compilation in Dincecco (2011). & Fiscal / Legal \\
\hline
\end{tabular}

Source: extract from Cingolani (2013). 


\subsection{Country coverage for BAIndex}

\begin{tabular}{|l|}
\hline Europe \& Central Asia \\
\hline Albania (1992-2010); Austria (1990-1998); Armenia (1994-2010); Belgium (1990-1998); Bosnia and \\
Herzegovina (1998-2010); Bulgaria (1990-2010); Croatia (1991-2010); Czech Republic (1990-2010); \\
Denmark (1990-2010); Estonia (1990-2010); Finland (1990-1998); France (1990-1998); Georgia (1990-2010); \\
Germany (1990-1998); Greece (2000-2010); Hungary (1990-2010); Ireland (1990-1998); Italy (1990-1998); \\
Kazakhstan (1990-2010); Kyrgyz Republic (2007-2010); Latvia (1991-2010); Lithuania (1991-2010); \\
Netherlands (1990-1998); Norway (1990-2010); Poland (1990-2010); Portugal (1990-1998); Russia \\
(1990-2010); Slovak Republic (1994-2008); Slovenia (1992-2006); Spain (1990-1998); Sweden (1990-2010); \\
Switzerland (1990-2010); Turkey (1990-2010) \\
\hline South Asia \\
\hline Afghanistan (2003-2010); Bangladesh (1990-2010); Sri Lanka (1990-2010); India (1990-2010); Nepal \\
(1990-2010); Pakistan (1990-2010) \\
\hline East Asia \& Pacific \\
\hline Australia (1990-2010); China (1990-2010); Indonesia (1990-2010); Japan (1990-2010); Malaysia \\
(1990-2010); New Zealand (1990-2010); Philippines (1990-2010); Vietnam (1990-2010); Thailand \\
(1990-2010) \\
\hline Middle East \& North Africa \\
\hline Algeria (1990-2010); Bahrain (1990-2010); Djibouti (1990-1998); Iran (1990-2010); Iraq (2003-2010); \\
Israel (1990-2010); Jordan (1990-2010); Kuwait (1990-2010); Lebanon (1990-2010); Libya (1990-2010); \\
Morocco (1990-2010); Qatar (1990-2010); Saudi Arabia (1990-2010); Syria (1990-2010); Tunisia \\
(1990-2010) \\
\hline Latin America \& Caribbean \\
\hline Argentina (1990-2010); Chile (1990-2010); Colombia (1990-2010); Costa Rica (1990-2010); Dominican \\
Republic (1990-2010); El Salvador (1990-2010); Guatemala (1990-2010); Haiti (1990-2010); Honduras \\
(1990-2010); Jamaica (1990-2010); Mexico (1990-2010); Nicaragua (1990-2009); Paraguay (1990-2010); Peru \\
(1990-2010); Trinidad and Tobago (1990-2010) \\
\hline North America \\
\hline Canada (1990-2010) \\
\hline Sub-Saharan Africa \\
\hline Botswana (1990-2010); Gambia (1990-2010); Ghana (1990-2010); Kenya (1990-2010); Malawi (1990-2010); \\
Mauritius (1990-2010); Mozambique (1990-2010); Nigeria (1990-2010); Rwanda (2008-2010); South Africa \\
(1990-2010); Zimbabwe (1990-2010); Sudan (1990-2010); Swaziland(1990-2010); Uganda (1990-2010) \\
\hline
\end{tabular}


6.3 Bureaucratic Autonomy Index and Regime Type

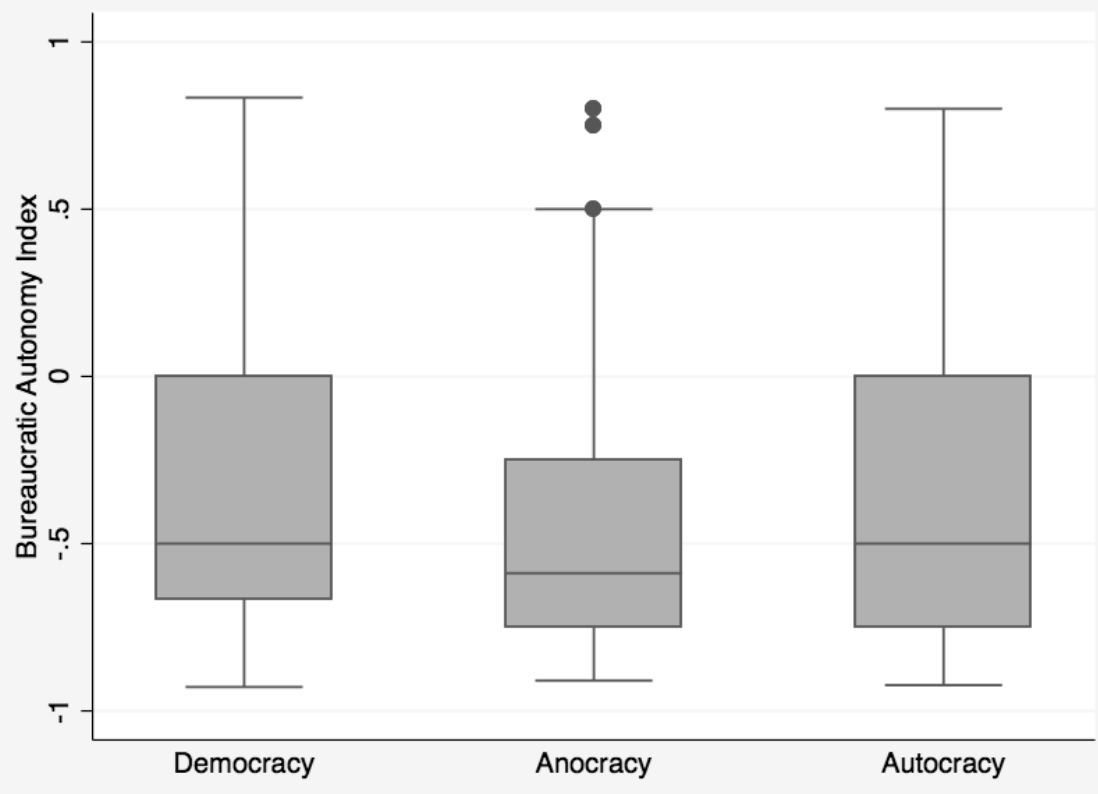




\subsection{Bureaucratic Autonomy Index: consistency with similar indicators}
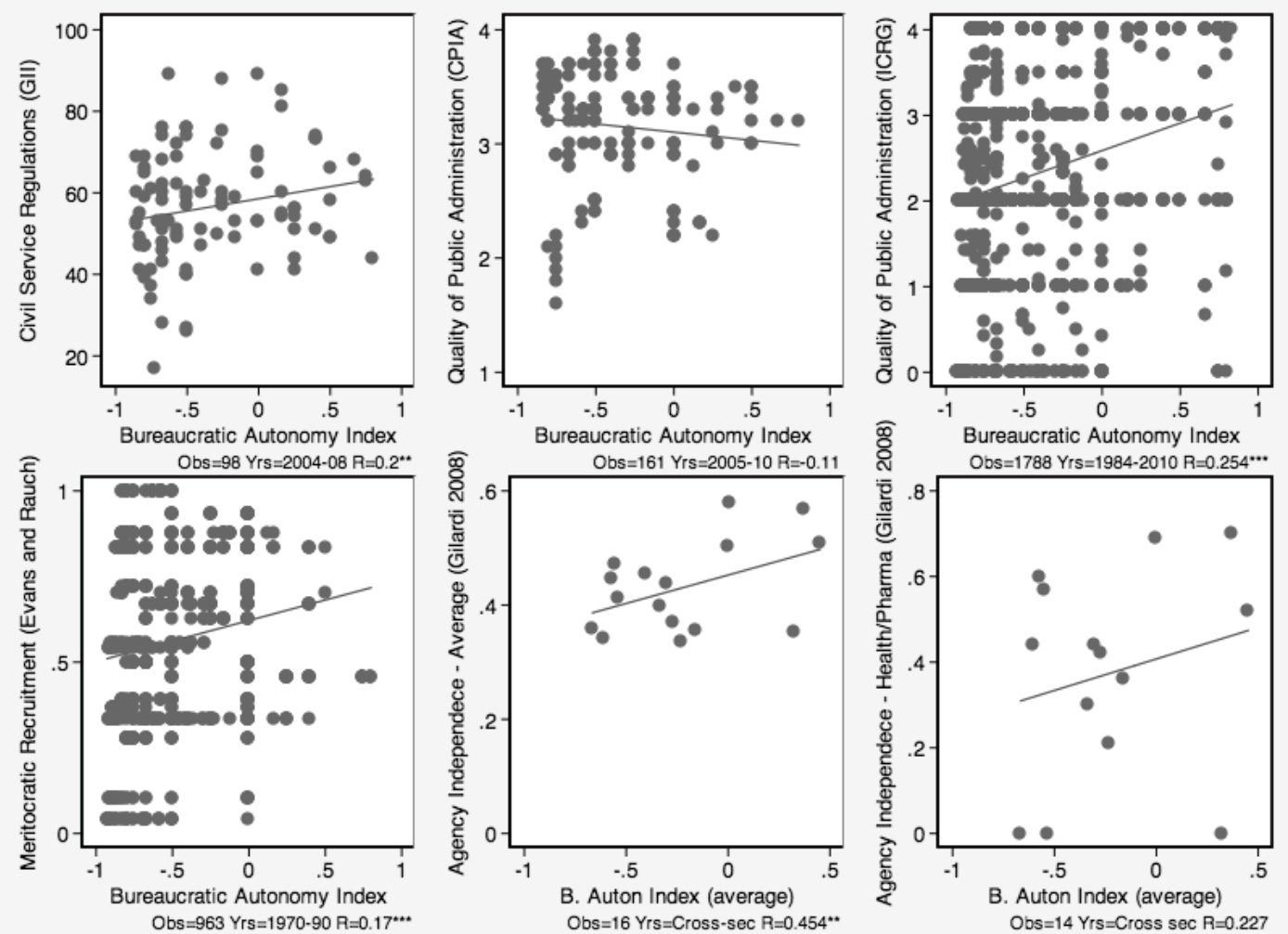


\subsection{State capacities and MDGs: Variables and descriptive stats}

\begin{tabular}{|c|c|c|c|c|c|c|c|}
\hline Variable & Description & Source & Countries (Years) & Mean & St. Dev & Min & $\operatorname{Max}$ \\
\hline Child Mortality & $\begin{array}{l}\text { Mortality rate, under } 5 \text { years old } \\
\text { (per } 1,000 \text { ) }\end{array}$ & $\begin{array}{l}\text { World Development } \\
\text { Indicators }\end{array}$ & $142(1990-2010)$ & 62.434 & 61.054 & 2.6 & 311 \\
\hline $\begin{array}{l}\text { Tuberculosis } \\
\text { Prevalence }\end{array}$ & $\begin{array}{l}\text { Prevalence of tuberculosis (per } \\
100,000 \text { people) }\end{array}$ & $\begin{array}{l}\text { World Development } \\
\text { Indicators }\end{array}$ & $142(1990-2010)$ & 210.262 & 226.515 & 1.1 & 1307 \\
\hline $\begin{array}{l}\text { Bureaucratic } \\
\text { Autonomy Index }\end{array}$ & $\begin{array}{l}\text { Measures yearly changes in } \\
\text { bureaucratic autonomy (see Table } \\
\text { 1) }\end{array}$ & $\begin{array}{l}\text { Based on Dreher, } \\
\text { Sturm and deHaan } \\
(2010)\end{array}$ & 93 (1990-2010) & -0.433 & 0.433 & -0.928 & 0.833 \\
\hline Tax revenue & $\begin{array}{l}\text { Revenue from taxes as share of } \\
\text { GDP, in the budgetary base of the } \\
\text { central government }\end{array}$ & $\begin{array}{l}\text { Government Finance } \\
\text { Statistics, International } \\
\text { Monetary Fund }\end{array}$ & $119(1990-2010)$ & 16.106 & 7.528 & 0.112 & 60.489 \\
\hline Democracy & $\begin{array}{l}\text { Continuous variable measuring the } \\
\text { level of democracy }\end{array}$ & Polity IV & $140(1990-2010)$ & 2.895 & 6.764 & -10 & 10 \\
\hline Per capita GDP & $\begin{array}{l}\text { Ln of GDP per capita, US dollars, } \\
\text { chain series }\end{array}$ & $\begin{array}{l}\text { New Maddison } \\
\text { Historical Datasets }\end{array}$ & $140(1990-2010)$ & 8.173 & 1.136 & 5.315 & 10.276 \\
\hline GDP growth & Annual GDP growth (\%) & $\begin{array}{l}\text { computed from New } \\
\text { Maddison Historical } \\
\text { Datasets }\end{array}$ & $140(1990-2010)$ & 0.0165 & 0.066 & -0.954 & 0.625 \\
\hline Population growth & Annual population growth (\%) & $\begin{array}{l}\text { World Development } \\
\text { Indicators (World } \\
\text { Bank) }\end{array}$ & $142(1990-2010)$ & 1.551 & 1.598 & -7.533 & 18.588 \\
\hline Female Education & $\begin{array}{l}\text { Mean years of educational } \\
\text { attainment in women in } \\
\text { reproductive age (15-44) }\end{array}$ & $\begin{array}{l}\text { Gakidou et. al. } 2010 \\
\text { and Barro and Lee } \\
\text { (forthcoming) }\end{array}$ & $141(1990-2010)$ & 7.651 & 3.625 & 0.3 & 14.7 \\
\hline Urbanization & $\begin{array}{l}\text { Population living in urban areas } \\
(\%)\end{array}$ & $\begin{array}{l}\text { World Development } \\
\text { Indicators }\end{array}$ & $142(1990-2010)$ & 53.870 & 22.233 & 5.416 & 100 \\
\hline Immunization & $\begin{array}{l}\text { Average of the share of } \\
\text { one-year-old children immunized } \\
\text { against hepatitis B, BCG and Polio }\end{array}$ & $\begin{array}{l}\text { World Development } \\
\text { Indicators }\end{array}$ & $142(1990-2010)$ & 83.091 & 16.270 & 11.5 & 99 \\
\hline Safe water & $\begin{array}{l}\text { Improved water source ( } \% \text { of } \\
\text { population with access) }\end{array}$ & $\begin{array}{l}\text { World Development } \\
\text { Indicators }\end{array}$ & $139(1990-2010)$ & 81.743 & 19.370 & 2 & 101 \\
\hline State Fragility Index & $\begin{array}{l}\text { Composite index on } 8 \text { stateness } \\
\text { dimensions }\end{array}$ & Polity IV (2011) & $140(1990-2010)$ & 9.701 & 6.783 & 0 & 25 \\
\hline Health expenditure & $\begin{array}{l}\text { Health expenditure as share of } \\
\text { GDP, in the budgetary base of the } \\
\text { central government }\end{array}$ & $\begin{array}{l}\text { Government Finance } \\
\text { Statistics, International } \\
\text { Monetary Fund }\end{array}$ & 107 (1990-2010) & 1.442 & 1.345 & -0.008 & 8.748 \\
\hline $\begin{array}{l}\text { Social Protection } \\
\text { expenditure }\end{array}$ & $\begin{array}{l}\text { Social protection expenditure as } \\
\text { share of GDP, in the budgetary } \\
\text { base of the central government }\end{array}$ & $\begin{array}{l}\text { Government Finance } \\
\text { Statistics, International } \\
\text { Monetary Fund }\end{array}$ & $107(1990-2010)$ & 3.425 & 3.888 & -0.928 & 20.069 \\
\hline Education expenditure & $\begin{array}{l}\text { Education expenditure as share of } \\
\text { GDP, in the budgetary base of the } \\
\text { central government }\end{array}$ & $\begin{array}{l}\text { Government Finance } \\
\text { Statistics, International } \\
\text { Monetary Fund }\end{array}$ & $107(1990-2010)$ & 2.969 & 1.834 & 0.024 & 14.316 \\
\hline
\end{tabular}

\subsection{Correlation Matrix}

\begin{tabular}{|c|c|c|c|c|c|c|c|c|c|c|c|c|c|c|c|c|}
\hline & 1 & 2 & 3 & 4 & 5 & 6 & 7 & 8 & 9 & 10 & 11 & 12 & 13 & 14 & 15 & 16 \\
\hline Child mortality (1) & 1 & & & & & & & & & & & & & & & \\
\hline Tuberculosis Prevalence (2) & .617 & 1 & & & & & & & & & & & & & & \\
\hline Bureaucratic Autonomy (3) & -.014 & .023 & 1 & & & & & & & & & & & & & \\
\hline Tax Revenue (4) & -.122 & -.021 & -.083 & 1 & & & & & & & & & & & & \\
\hline Democracy (5) & -.315 & -.110 & .123 & .200 & 1 & & & & & & & & & & & \\
\hline Ln GDP per capita (6) & -.840 & -.564 & .059 & .257 & .336 & 1 & & & & & & & & & & \\
\hline GDP growth (7) & -.175 & -.064 & .015 & -.036 & -.053 & .137 & 1 & & & & & & & & & \\
\hline Population growth (8) & .243 & .157 & .058 & -.020 & -.345 & -.171 & -.159 & 1 & & & & & & & & \\
\hline Female educ attainment (9) & -.732 & -.396 & .077 & .278 & .486 & .722 & .172 & -.344 & 1 & & & & & & & \\
\hline Urbanization (10) & -.667 & -.479 & .106 & .134 & .149 & .737 & .019 & .014 & .595 & 1 & & & & & & \\
\hline Immunization (11) & -.411 & -.376 & -.197 & .092 & .020 & .260 & .066 & -.140 & .261 & .235 & 1 & & & & & \\
\hline Safe Water (12) & -.816 & -.509 & .143 & .163 & .262 & .790 & .141 & -.199 & .595 & .661 & .292 & 1 & & & & \\
\hline State Fragility (13) & .783 & .511 & .000 & -.230 & -.472 & -.827 & -.106 & .250 & -.745 & -.629 & -.277 & -.681 & 1 & & & \\
\hline Health expend. (14) & -.086 & -.119 & -.046 & .434 & .044 & .122 & -.022 & .109 & .140 & .097 & .146 & .119 & -.135 & 1 & & \\
\hline Soc Prot. expend. (15) & -.421 & -.356 & -.068 & .370 & .330 & .551 & .000 & -.167 & .498 & .410 & .076 & .412 & -.494 & .351 & 1 & \\
\hline Educ. expend. (16) & .125 & .075 & -.093 & -.119 & -.017 & -.096 & -.164 & .197 & -.125 & -.062 & .127 & -.113 & .040 & .500 & .119 & 1 \\
\hline
\end{tabular}




\section{References}

Acemoglu, D. (2005). Politics and economics in weak and strong states. Journal of Monetary Economics, 52(7):1199-1226.

Acemoglu, D., Ticchi, D., and Vindigni, A. (2006). Emergence and persistence of inefficient states. National Bureau of Economic Research Working Paper Series, No. 12748.

Arthur, S. (1966). The Papers of Woodrow Wilson. Princeton: Princeton University Press.

Azevedo, J. P. Wbopendata: Stata module to access World Bank databases. Statistical software components S457234.

Bäck, H. and Hadenius, A. (2008). Democracy and state capacity: Exploring a j-shaped relationship. Governance, 21(1):124.

Barro, R. and Lee, J.-W. (2013). A new dataset of educational attainment in the world 1950-2010. Journal of Development Economics, 104:184-198.

Besley, T. and Persson, T. (2008). Wars and state capacity. Journal of the European Economic Association, 6(23):522-530.

Besley, T. and Persson, T. (2009). The origins of state capacity: Property rights, taxation, and politics. American Economic Review, 99(4):1218-1244.

Besley, T. and Persson, T. (2011). Pillars of Prosperity: The Political Economics of Development Clusters. Princeton University Press.

Bockstette, V., Chanda, A., and Putterman, L. (2002). States and markets: The advantage of an early start. Journal of Economic Growth, 7(4):347-369.

Bolt, J. and van Zanden, J. L. (2013). The first update of the maddison project; re-estimating growth before 1820. Maddison Project Working Paper 4.

Braithwaite, A. (2010). Resisting infection: How state capacity conditions conflict contagion. Journal of Peace Research, 47(3):311-319.

Buhaug, H. (2010). Dude, wheres my conflict? LSG, relative strength, and the location of civil war. Conflict Management and Peace Science, 27(2):107128.

Cárdenas, M. (2010). State Capacity in Latin America. Economía, 10(2):1-45.

Centeno, M. A. (2002). Blood and Debt: War and the Nation-State in Latin America. Penn State Press. 
Christensen, J. (2010). Public Interest Regulation Reconsidered: From capture to credible commitment. In Regulation at the Age of Crisis. ECPR Regulatory Governance Standing Group, 3rd Biennial Conference, University College, Dublin, June.

Christensen, J. G. and Nielsen, V. L. (2010). Administrative capacity, structural choice and the creation of EU agencies. Journal of European Public Policy, 17(2):176-204.

Cingolani, L. (2013). The State of State Capacity: a review of concepts, evidence and measures. UNU-Merit Working Paper Series 2013-053.

Dahlström, C., Lapuente, V., and Teorell, J. (2010). Dimensions of bureaucracy. A cross-national dataset on the structure and behavior of public administration, volume 13. QoG Working Paper Series.

DeRouen, K., Ferguson, M. J., Norton, S., Park, Y. H., Lea, J., and StreatBartlett, A. (2010). Civil war peace agreement implementation and state capacity. Journal of Peace Research, 47(3):333-346.

DeRouen, K. R. and Sobek, D. (2004). The dynamics of civil war duration and outcome. Journal of Peace Research, 41(3):303-320.

Dincecco, M. (2011). Political Transformations and Public Finances: Europe, 1650-1913. Cambridge University Press.

Dincecco, M. and Katz, G. (2012). State capacity and long-run performance. APSA 2012 Annual Meeting paper.

Dincecco, M. and Prado, M. (2012). Warfare, fiscal capacity, and performance. Journal of Economic Growth, 17(3):171-203.

Dreher, A., Sturm, J.-E., and Haan, J. d. (2010). When is a central bank governor replaced? Evidence based on a new data set. Journal of Macroeconomics, 32(3):766-781.

Dye, C., Lönnroth, K., Jaramillo, E., Williams, B., and Raviglione, M. (2009). Trends in tuberculosis incidence and their determinants in 134 countries. Bulletin of the World Health Organization, 87(9):683-691.

Evans, P. and Rauch, J. E. (1999). Bureaucracy and growth: A cross-national analysis of the effects of 'Weberian' state structures on economic growth. American Sociological Review, 64(5):748-765.

Evans, P. B. (1989). Predatory, developmental, and other apparatuses: A comparative political economy perspective on the third world state. Sociological Forum, 4(4):561-587. 
Evans, P. B. (1995). Embedded Autonomy. Princeton University Press.

Evans, P. B., Rueschemeyer, D., and Skocpol, T., editors (1985). Bringing the State Back In. Cambridge University Press.

Fearon, J. D. and Laitin, D. D. (2003). Ethnicity, insurgency, and civil war. American Political Science Review, 97(01):75-90.

Fortin, J. (2010). A tool to evaluate state capacity in postcommunist countries, 1989-2006. European Journal of Political Research, 49(5):654-686.

Fukuyama, F. (2012). The strange absence of the state in political science. The American Interest. Blog entry, February 2012.

Fukuyama, F. (2013). What is governance? Working Paper 314, Center for Global Development.

Gakidou, E., Cowling, K., Lozano, R., and Murray, C. (2010). Increased educational attainment and its effect on child mortality in 175 countries between 1970 and 2009: a systematic analysis. The Lancet, 376(9745):959974 .

Geddes, B. (1996). Politician's dilemma: building state capacity in Latin America. University of California Press.

Gilardi, F. and Maggetti, M. (2010). The independence of regulatory authorities. Handbook of Regulation.

Goodnow, F. J. (2003). Politics and administration: A study in government. Transaction Publishers.

Hamm, P. and King, L. (2010). Post-manichean economics: Foreign investment, state capacity and economic development in transition economies. Working Paper 227, Political Economy Research Institute, University of Massachusetts Amherst.

Hamm, P., King, L. P., and Stuckler, D. (2012). Mass privatization, state capacity, and economic growth in post-communist countries. American Sociological Review, 77(2):295-324.

Hanretty, C. and Koop, C. (2009). Measuring regulators statutory independence. APSA annual meeting paper.

Hanson, J. and Sigman, R. (2011). Measuring state capacity: Assessing and testing the options. APSA annual meeting paper.

Hargreaves, J., Boccia, D., Evans, C., Adato, M., Petticrew, M., and Porter, J. (2011). The social determinants of tuberculosis: from evidence to action. American journal of public health, 101(4):654. 
Henderson, J., Hulme, D., Jalilian, H., and Phillips, R. (2007). Bureaucratic effects: Weberian state agencies and poverty reduction. Sociology, 41(3):515532 .

Hendrix, C. S. (2010). Measuring state capacity: Theoretical and empirical implications for the study of civil conflict. Journal of Peace Research, $47(3): 273-285$.

Johnson, K. and Arbetman Rabinowitz, M. (2005). Relative political capacity model \& data description. Paper prepared for the Workshop on Political Economy. Claremont Graduate University.

Karl, T. L. (1997). The Paradox of Plenty: Oil Booms and Petro-States. University of California Press.

King, R. G. and Levine, R. (1993). Finance and growth: Schumpeter might be right. The Quarterly Journal of Economics, 108(3):717-737.

Kohli, A. (2004). State-Directed Development: Political Power and Industrialization in the Global Periphery. Cambridge University Press.

Kugler, J. and Arbetman, M. (1997). Relative political capacity: Political extraction and political reach. Political capacity and economic behavior, pages $11-45$.

Leipziger, D., Fay, M., Wodon, Q., and Yepes, T. (2003). Achieving the Millennium Development Goals: The Role of Infrastructure. World Bank Policy Research Working Paper 3136.

Liu, L., Johnson, H., Cousens, S., Perin, J., Scott, S., Lawn, J., Rudan, I., Campbell, H., Cibulskis, R., Li, M., et al. (2012). Global, regional, and national causes of child mortality: an updated systematic analysis for 2010 with time trends since 2000. The Lancet, 379(9832):2151-2161.

Lönnroth, K., Williams, B., Cegielski, P., and Dye, C. (2010). A consistent log-linear relationship between tuberculosis incidence and body mass index. International journal of epidemiology, 39(1):149-155.

Maddison, A. (2012). Statistics on world population, gdp and per capita gdp, 1-2008 ad. Groeningen Growth and Development Centre. Retrieved from: http://www.ggdc.net/MADDISON/oriindex.htm.

Mann, M. (1986). The Sources of Social Power: A history of power from the beginning to A.D. 1760. Cambridge University Press.

Mann, M. (1993). The Sources of Social Power: The Rise of Classes and Nation-States, 1760 - 1914. Cambridge University Press. 
Marshall, M. G. and Jaggers, K. (2013). Polity IV project: Political regime characteristics and transitions, 1800-2011.

North, D. C., Wallis, J. J., Webb, S., and Weingast, B. (2011). Limited access orders: An introduction to the conceptual framework. In How Institutions Matter: The Interplay of Economics and Politics as the Drivers of Development. Outcomes: Evidence from Nine Countries., volume Internal document. Washington, D.C.

Rauch, J. E. and Evans, P. B. (2000). Bureaucratic structure and bureaucratic performance in less developed countries. Journal of Public Economics, 75(1):49-71.

Skocpol, T. (1979). States and social revolutions: a comparative analysis of France, Russia, and China. Cambridge University Press.

Sobek, D. (2010). Masters of their domains: The role of state capacity in civil wars. Journal of Peace Research, 47(3):267 -271.

Soifer, H. (2008). State infrastructural power: Approaches to conceptualization and measurement. Studies in Comparative International Development, $43(3-4): 231-251$.

Soifer, H. and vom Hau, M. (2008). Unpacking the strength of the state: The utility of state infrastructural power. Studies in Comparative International Development, 43(3-4):219-230.

Teorell, J., Samanni, M., Holmberg, S., and Rothstein, B. (2011). The Quality of Government Dataset, version 6Apr11. University of Gothenburg: The Quality of Government Institute, http://www.qog.pol.gu.se.

Thies, C. G. (2010). Of rulers, rebels, and revenue: State capacity, civil war onset, and primary commodities. Journal of Peace Research, 47(3):321 -332.

Tilly, C. (1975). The formation of national states in europe. Princeton: Princeton University.

UNESCAP (2007). Access to basic services for the poor the importance or good governance. Asia Pacific MDG Studies Series, (ST/ESCAP/2438).

Vaughan, M. K. (1997). Cultural Politics in Revolution: Teachers, Peasants, and Schools in Mexico, 1930-1940. University of Arizona Press.

Wang, L. (2003). Determinants of child mortality in ldcs: empirical findings from demographic and health surveys. Health policy, 65(3):277-299.

Weber, E. (1976). Peasants into Frenchmen: The Modernization of Rural France, 1870-1914. Stanford University Press. 
Weber, M. (1978). Economy and society: An outline of interpretive sociology (2 volume set). University of California Press. 


\title{
Chapter 3
}

\section{Meddle or Tie your Hands? Bureaucratic technologies for Adaptability and Predictability in Argentina and Brazil}

\author{
Luciana Cingolani*
}

\begin{abstract}
Depending on their disciplinary lens, scholars claim that state capacity requires either pro-predictability or pro-adaptability institutions. The way to resolve the tension between the two and find a virtuous balance is, however, much less explored. This article undergoes a first exploration of a novel and comprehensive database of bureaucratic structures, civil service appointments, career paths and agencification trends in Argentina and Brazil (1990-2010) in order to capture and compare the characteristics of national bureaucracies as technologies of predictability and adaptability. It looks at the complementarities between the two and the different scenarios taking place in Brazil (a state closer to the developmental type) and Argentina (a state closer to the neo-patrimonial type). Finally, the article explores the generalities of the political economy behind these contrasting patterns.
\end{abstract}

\section{Introduction}

While the notion of state capacity became increasingly important in order to account for a multiplicity of phenomena in the development discourse, it has been equally stretched to encompass a wide range of interpretations (Hendrix 2010; Hanson and Sigman 2013; Cingolani 2013; Cingolani, Thomsson and de Crombrugghe 2013).

*Maastricht Graduate School of Governance - UNU-Merit. Email: cingolani@ merit.unu.edu 
Two main analytical challenges surround this literature. First, how to resolve the demand for higher constraints to executive powers (e.g. in the form of better parliamentary and judicial institutions), while also preserve executives that provide the necessary order and unity for markets to flourish. Second, how to disentangle the contributions of different players within the executive power itself when building state capacity. In that sense, the literature has in general failed to reconcile the need to build government capabilities for ruling coalitions as enforcers of momentary (and changing) democratic preferences, versus the need to build capacity within the permanent bureaucracies in order to guarantee the continuity of procedures in time, as well as solve credibility problems.

There are widespread reasons why these factors are commonly conflated in the state capacity literature. In general, the empirical knowledge about state bureaucracies is still in its infancy (Brans 2003; Lapuente 2007; Dahlstrom, Lapuente and Teorell 2010; Fukuyama 2012). The absence of readily available measures of civil service characteristics has prompted an all-encompassing understanding of the state and little differentiation of its many elements in cross-country empirical comparisons. Additionally, different strands of literature accounting for the role of the state in development have barely come together. This is the case, for instance, of development economics and the literature on bureaucratic politics in general. While the first tends to simplify state characteristics in order to favor higher abstraction level analytics, the second is more aware of the inner tensions and overall complexity, often at the risk of affecting international comparability.

The present article aims to make a few contributions towards enriching discussions about administrative state capacity, by placing the politics-bureaucracy divide at the center, and acknowledging its consequences for policy adaptability and predictability. In this endeavor, it advances a comparative and empirical exploration of the way in which state structures of the executive power effectively operate as technologies for predictability and adaptability. It does so by exploiting an originally compiled database on bureaucratic structures, civil service appointments, career paths and agencification trends in Argentina and Brazil from 1990 to 2010. The comparison has the ultimate objective of observing the contrasting patterns in terms of bureaucratic predictability and adaptability of two different types of states, Argentina -closer to the neopatrimonial type-, and Brazil -closer to the developmental type-.

It also conciliates different approaches to state capacity by understanding capacity as an appropriate optimization of predictability and adaptability institutional technologies, and acknowledging that states might benefit from a different mix during different stages of development or circumstances. Here, 
bureaucracies are not conceived as monolithic or coherent bodies, but as complex 'configurations of organizations' (Zuvanic, Iacoviello and Rodriguez Gustá 2010; North et Al. 2012).

The next section briefly describes different literature strands that the article interacts with. The first are selected works on bureaucratic politics: principalagent models, bureaucratic appointments and transfers, and cabinet instability studies. A second strand is agencification theory and the regulatory state. Finally, the literature on the developmental state and the so called pockets of efficiency within public bureaucracies. From different perspectives, all three account for the dynamics of the politics-bureaucracy relationship and its implications. The third section presents the main hypotheses under the argument that state capacity requires a combination of adaptability and predictability technologies within the state apparatus, and that the balance between the two is regulated by the politics-bureaucracy relationship. The fourth section introduces the general institutional and economic features of Argentina and Brazil, presents the database and describes the methodology used. The fifth section lays out the analytical dimensions to be explored, and shows the main results. The sixth section provides an overview of the political economy reasons behind the patterns found. The final section concludes.

\section{Theories on bureaucracies}

This section briefly reviews a series of theories that consider the dynamics of the politics-bureaucracy relationship as an important aspect of countries' institutional maturity. Here, it is considered that this relationship has implications regarding the adaptability and stability of policies over time, and that the balance among the two is an important feature of administrative state capacity.

Directly or indirectly, several strands of literature address this relationship. Principal-agent models do so by resorting to positive, formal and micro-analytical methodologies; agencification theories take on a normative micro approach, while the literature on pockets of efficiency and the developmental state relies on a rather normative but macro-sociological perspective, where state structure aspects interact with other relevant determinants of development.

\subsection{Principal-agent models and bureaucratic politics}

The literature on delegation dedicates great efforts to depicting the interactions between 'principals' (normally, elected leaders: presidents, ministers or 
representatives) and 'agents' (bureaucrats or agencies). These scholars seek to uncover the different incentives and strategies that shift power to one side or the other and their different implications, mainly in the context of consolidated Western democracies ${ }^{1}$. A common challenge has been unraveling different political strategies to control bureaucrats, who normally enjoy a privileged position towards information and expertise in the face of the policymaking process.

While some classic authors explore the president's strategies and incentives to politicize the bureaucracy and influence bureaucratic structures (Neustadt 1960, Heclo 1977, Moe 1985), others examine this from the perspective of the legislative power. Subscribing to the congressional dominance theory, for example, the works of McCubbins, Noll and Weingast (1987 and 1989) show the various ways in which elected representatives design and control bureaucratic structures in order to favor their constituencies. Similarly, Calvert, McCubbins and Weingast (1989) develop a model of mutual accommodation between bureaucrats and politicians, distinguishing between bureaucratic authority and bureaucratic discretion. Later on, Huber and Shipan (2002) develop a theory on deliberate delegation accounting for the tradeoff between the need of policy experts and the risk of granting too much authority to bureaucrats. A similar issue is explored by Geddes (1996) in the context of Latin America, seeking to capture the incentives to appoint bureaucrats either on partisan or meritocratic grounds. Hammond and Knott (1996) study multiple sources of bureaucratic control and the conditions under which bureaucratic autonomy varies. Bertelli and Feldmann (2007) develop a spatial model of presidential strategies for appointments to independent agencies, considering constituents' preferences and consensus mechanisms between agencies and constituents.

Other scholars have studied how delegation is affected by state capacity (Dixit 2006), the political regime (Dixit 2010) and cabinet instability (Huber and Lupia 2001), leading in some cases to suboptimal policies. Gailmard and Patty (2007) put forth a model of how human resource management systems in the civil service interact with bureaucratic discretion to promote policy-motivated officials. Alesina and Tabellini (2007 2008) study the optimal allocation of policies among elected politicans and bureaucrats, considering the nature of policies (redistributive, technical, etc.) and the skills of bureaucrats. Iyer and Mani (2012) study elected politicians' strategies to control career-oriented bureaucrats and how this, in turn, affects the future of bureaucrats' careers in India.

\footnotetext{
${ }^{1}$ Bendor, Glazer and Hammond (2001) and Gailmard and Patty (2012) provide overviews of game-theory models along these lines.
} 


\subsection{Agencification theory and bureaucratic autonomy}

In contrast to the literature on delegation, agencification scholars tend to take a more normative approach, where agency insulation or independence is a key aspect of institutional maturity. Theorizations on the regulatory state (Majone 1994 1997) and 'regulatory capitalism' (Levi-Faur, 2005) have given an important boost to agencification works, especially in the context of EU institutions. This literature has come a long way in the description, typification, measurement and general analysis of independent national and supra-national agencies. It mostly focuses on regulatory entities, although not exclusively.

Gilardi (2008) observes the institutional diffusion of regulatory agencies across countries and sectors whenever new agencies are created. Jordana, Levi-Faur and Fernandez i Marin (2011) further study patterns of agency diffusion using a dataset of 48 countries and 16 sectors since 1920. They argue that international diffusion is a more important determinant of agency creation than the more typical arguments on credibility and insulation. Moreover, Christensen (2010) shows that independent agencies have spread into social policy areas, claiming that credibility is not necessarily the main concern behind their creation. The article by Gilardi and Maggetti (2011) provides an overview of the multiple dimensions of agency independence and variations across the world, and proposes a strategy to operationalize agency independence. A similar quest is undertaken by Hanretty and Koop (2009), who propose an alternative way to measure agency independence. Using a database for the Netherlands, Denmark and Sweden between 1945 and 2000, Yesilkagit and Christensen (2010) show that path-dependency and historical factors predominate when explaining the institutional design of regulatory agencies, while commonly cited explanations related to political uncertainty and conflict play an insignificant role.

Along similar lines, several works have studied the political aspects of meritbased versus patrimonial systems, focusing on the concept of bureaucratic autonomy and insulation. The famous work by Carpentier (2001) takes a long-term historical approach to understand how important agencies such as USDA or the Post Office Department acquired autonomy in the years of the Progressive Era, showing that the expertise of mezzo-level officers was particularly important in sponsoring essential innovations. Yesilkagit (2004) develops a model of mutual adaptation between politicians and newly-created independent agencies in the Netherlands, while Lapuente and Nistotskaya (2009) explain how merit systems arise beyond Anglo-Saxon democracies. Dahlström and Lapuente (2012) show two different types of separation between politicians and bureaucrats, namely the separation of their careers and the separation of 
their activities. They argue that different things can be expected from each in the fight against corruption: career separation has a stronger effect. Rasul and Rogger (2013) show that civil service management affects the efficiency of public policies in Nigeria, and that while bureaucratic autonomy is positively correlated with higher completion rates in infrastructural works, 'performance' incentives fail to serve this same purpose.

\subsection{Developmental, Neo-Patrimonial states, Pockets of Effi- ciency}

Taking on a firmly normative and macrosociological perspective, a vast literature looking at the administrative aspects of neopatrimonial states has emerged several decades ago. This literature departs from Europe and the U.S. in order to focus on countries with lower state capacity.

Much of this scholarship has flourished in the framework of general typologies depicting developmental versus non-developmental states. Evans (1989) dedicates important efforts to compare and characterize states that are predatory, intermediate or developmental, depending on their degree of meritocratic management, as well as the institutionalized connections between the private sector and the civil service. These mechanisms became later consolidated under the notion of 'embedded autonomy' (Evans 1995).

The work of Mèdard (1991) contributes further to the exploration of neopatrimonial states, in this case with a strong focus on North Africa. Bach (2011) provides a more nuanced approach, by which several empirical options can be found underneath this umbrella concept, most notably 'regulated' versus 'predatory' forms of neopatrimonialism. Kholi (2004) theorizes about the developmental state, arguing that the transformative capacity to define clear goals and mobilize resources from the society towards that end explains levels of development.

The concept of 'pockets of efficiency' or 'effectiveness' (PoEs) has recently acquired renewed momentum. These pockets are "public organisations which deliver public services relatively effectively in contexts of largely ineffective government" (Roll 2011: 1). The notion was originally coined by Geddes (1986) to describe efficiency clusters within the Brazilian bureaucracy, but Evans (1989 1995) made it widely popular at a cross-country level.

Recent publications have continued to emphazise the importance of PoEs for development. Hout (2007) provides an insightful analysis of the Surinamese State Oil Company on its trajectory to becoming a PoE within a context of neopatrimonial institutions. He finds that the strategic importance of oil pro- 
duction, the progressive autonomy granted to it, and the social mobilization in favor of national production all greatly helped in explaining the company's efficiency. Leonard (2010) examines a series of hypotheses regarding the explanations behind the emergence of these pockets in the developing world, while Roll (2011) explores multiple aspects of PoEs, in particular their definition and determinants. The book by Roll (2014) represents a compilation of works around the political determinants of PoEs, with comparative case studies of public organizations and enterprises across all regions of the developing world.

This brief overview suggests that many different perspectives coexist when it comes to understanding the nature of the politics-bureaucracy relationship, and that to a great extent these are suited for different purposes and contexts. While the delegation literature is largely American, the agencification literature is rather a derivation of the discussions on the regulatory state in Europe. The developmental state literature, on the other hand, focuses exclusively on developing or fragile states, although mostly through a developedworld lens. One possible conclusion is that comprehensive knowledge on the politics-bureaucracy relationship in developing or transition countries is still lagging behind. Also, the link between the micro-political economy of bureaucracies and the more general notion of state capacity is at best, weak. In the following sections, I undertake an empirical study to explore the dynamics of the politics-bureaucracy relationship in two emerging economies, while interacting with current discussions on state capacity.

\section{Main Argument and hypotheses}

As first anticipated, the politics-bureaucracy divide is at the core of the present analysis. Bureaucrats and politicians both take part in the policymaking process, but they face different career incentives and time-horizons, and have different access to information and tools to interpret facts.

In its simplest form, the reasoning supported here is that because career bureaucrats generally have longer term perspectives -instead of facing strong pressures to respond directly to democratic or interest group preferences-, a more consolidated professional bureaucracy will favor overall higher policy predictability. In contrast, a strong political dominance over the bureaucracy will facilitate adaptability to new contexts, sometimes at the risk of hindering credible commitments. Newer management formats such as New Public Management have slightly altered this reasoning by granting more flexibility to the bureaucracy, but the general idea remains valid for most countries around 
the world, which are still struggling to achieve the minimum standards of a modern bureaucracy.

Although the politics-bureaucracy relationship defines much of the administrative technologies for adaptability and predictability, the final state's capacity to adapt to changes or maintain commitments depends upon multiple factors and institutions besides the bureaucracy.

A number of scholars have studied the tradeoff between adaptable and predictable institutions from different perspectives. This tension is, for example, largely explored by the theories on veto players (Tsebelis 1995 2002). These strands use public choice spacial models to explain policy change and decisionmaking outcomes in terms of the number and nature of the relevant veto players involved in a policy decision, understood as the number of individual or collective institutional players that are formally and informally able to veto a decision. In general terms, the theory predicts that the higher the number of veto players within a polity, the more stable policies will be (at the same time, more prone the system will be to paralysis). Haggard and McCubbins (2001) expand these ideas for the particular context of presidential systems. They contrast decisiveness, the ability to change policy, and resoluteness, the capacity to maintain commitments.

Using repeated game theory, Scartascini, Stein and Tommasi (2008) offer a conciliatory view of the tradeoffs proposed by the veto players theory. They argue that if the decision-making process takes place within a context of repeated interactions among players, both adaptability and stability might be achieved at once. A series of political configurations favor cooperation among players, such as institutionalized party systems, legislatures with substantial policymaking powers, professional bureaucracies and independent judiciaries (: 16).

In the present work, the focus is exclusively on the bureaucracy. But instead of conceiving it as a single unified player as in many theories on veto players and extensions, bureaucracies are seen as versatile and complex matrices of power allocation and policymaking authority, where multiple players and interests coexist and overlap in time. This view follows Zuvanic, Iacoviello and Rodriguez Gustá (2010), who portray bureaucracies as organizational configurations: "it would be incorrect to say that a national case has a single bureaucracy; rather it has multiple types of bureaucracies or organizational configurations" (: 160).

At the same time, this has implications for the analysis of the administrative capacity for predictability and adaptability. I argue that although tradeoffs between the institutions that foster predictability versus adaptability exist, the 
bureaucracy as a complex configuration hosts administrative technologies for both within its scope. These can normally be disentangled from one another, and the nature of their complementarities or tensions provides a more general profile of the state's administrative capacities.

In particular, it is hypothezised here that a state closer to the developmental type will have a clearer division of both technologies within its bureaucracy, and that each will tend to be well developed and legally protected. In states closer to neopatrimonial types, the political sphere will dominate over the bureaucracy, and therefore the technologies for predictability will be much less developed.

Taking on an empirical and comparative approach, the article will exploit comprehensive data on bureaucratic structures, appointments and agencification patterns to capture both the degree of adaptability and predictability potential in Argentina and Brazil during most of their recent post-democratic lives.

\section{Cases, methods and database}

\subsection{Institutions in Argentina and Brazil}

Argentina and Brazil enjoy a substantial degree of similarity in their constitutions and recent institutional history. As many other Latin American countries, they both underwent re-democratization in the early eighties, after several shifts back and forth between democratic and authoritarian rule throughout the 20th century. They are both presidential systems with bicameral legislatures and a federal territorial organization, where both governors and municipal leaders are publicly-elected. Both countries have chosen proportional electoral systems for their lower chambers, although Brazil's is more proportional, which has induced a more fragmented Congress, as well as the proliferation of coalition agreements. In both Argentina and Brazil, however, the president enjoys very strong constitutional powers and can issue decrees and veto legislation. In both cases the constitution allows up to two consecutive 4-year terms in office since 1994, while immediate reelection was banned previously. In both countries sub-national politics plays a key role at the national level.

Regarding their bureaucracies, some institutional differences arise. Although both civil services are highly positioned in terms of quality within the Latin American universe, Brazil ranks first in a meritocracy index developed by 
Longo (2002 2004) with 87 out of 100 points (highly meritocratic), while Argentina ranks fourth with 52 points (mixed meritocratic / patronage). Regarding career management systems or functional capacity, Brazil also ranks first (61 points), with important competitiveness schemes introduced, internal equity and clear wage management systems, while Argentina (46 points) is among the mid-range countries due to lower competitiveness and higher inequality, in spite of some measures introduced. Argentina also suffers from high forced rotation of high performers (Zuvanic, Iacoviello and Rodriguez Gustá (2010).

Their economic governance and structures also vary greatly. Brazil's economy is five times bigger of that of Argentina, and is endowed with highly diversified industry and services sectors. Argentina's economy revolves around agricultural commodity exports and some industrial by-products. More details about the economic contrast between the countries are provided in section 6 .

In general, Brazil's outstanding development during the last decades has granted it recognition as meeting many attributes of developmental states (e.g. Wade 2010). In the case of Argentina a more mixed picture emerges, where scholars tend to label it closer to the neo-patrimonial type (e.g. Von Soest 2009), or at least they hardly ever situate it within the list of developmental states.

\subsection{Methods}

The methodology chosen here consists of a comparative historical analysis of the two countries between 1990 and 2010. The analysis is made using original empirical data that is equivalent and objective for the two cases. From this data, general statistical patters are extracted in order to visualize the differences between the countries. These differences are, in turn, analyzed as determinants of a series of political economy dimensions over time.

\subsection{The database}

For each country, I have compiled a database gathering information on several aspects of the national public administration between 1990-2010. First, I registered the existing organizational chart for each year under study, meaning an exhaustive listing of all the organizational units within the executive power in the form of ministries and all their depending secretaries and undersecretaries. After the 20 years, these units total 1061 for Argentina and 1569 for $\mathrm{Brazil}^{2}$. Second, I listed the names of all autonomous agencies existing be-

\footnotetext{
${ }^{2}$ In the case of Brazil, however, there is missing data for the cabinet office (Casa Civil).
} 
tween 1990 and 2010 along with their dates of creation, their location in the organizational chart, as well as some additional information about their legal aspects. These agencies amount to 74 in Argentina and 46 for Brazil. Third, I collected data on the names and dates of appointment and removal of the head officials in each of these two types of organizational units throughout the period (agencies and cabinet units), a total of 1419 officials for Argentina and 1643 for Brazil. Finally, combining the former three items, I built a database for each country with the career paths of the officials entering the sample ${ }^{3}$. Although the database is highly exhaustive, around $20 \%$ of the data points are random missings. More details can be found in the Appendix.

\section{Analytical categories and Results}

The information in the database will allow an objective and detailed comparison between the two countries in terms of their administrative technologies for adaptability and predictability for the period examined. As anticipated, administrative adaptability potential is here understood as a county's capability of introducing changes in the central administrative apparatus in correspondence with changes in democratic preferences or economic shocks. Predictability, on the other hand, is the capacity to maintain medium or longterm policy commitments. Although in general the institutional incentives that foster adaptability hinder predictability and vice versa, bureaucracies as complex configurations may allow the existence of both technologies through different mechanisms at the same time.

Given the information gathered, the adaptability to democratic preferences is here assessed through the analysis of different patterns within the central administration (ministries and sub-units), while predictability is analyzed through the descentralized or autarchic administration, here autonomous agencies.

\subsection{Adaptability}

Argentina and Brazil are compared on two adaptability dimensions. First, I compute a simple formula to measure inter-annual variations in the organizational charts (OCV) for each country, as follows:

\footnotetext{
${ }^{3}$ Data on organizational charts was collected from the searchable databases of legislation, in Argentina the site infoleg.gov and in Brazil legislacao.planalto.gov.br. Data on appointments was collected from the scanned and digital copies of both countries' daily official newsletters: the Boletin Oficial in Argentina and the Diario Oficial da Uniao in Brazil. Wikipedia and local newspapers served as complementary sources when necessary.
} 


$$
O C V_{j}=\frac{\sum_{i=1}^{s}\left(U_{i j}^{n}-U_{i j-1}^{n}\right)^{2}}{\sum_{i=1}^{s} M A X\left[U_{i j}^{n} ; U_{i j-1}^{n}\right]}
$$

Where $j$ are the years between 1991 and 2010 (give that data starts in 1990), $i$ are the individual organizational units, where units $(\mathrm{U})$ can be of a nature $m$ (Ministry), $s$ (Secretary) or $u$ (Undersecretary). $U_{i j}^{m}, U_{i j}^{s}$ and $U_{i j}^{u}$ equal 1 if they exist and 0 otherwise, so that, for example, $U_{2,1999}^{m}=1$ is the existence of ministry 2 in 1999, and the same for secretaries and undersecretaries. The index takes a value between 0 (no change at all) and 1 (complete change). Changes happen when either a new unit is created, terminated or its denomination is changed. If, for example, all ministries change from one year to the next, the index takes a value of 1 , as each ministry will automatically drag changes in their depending units (each sub-unit is considered different if they are under a different ministry even when its particular denomination does not change). In contrast, if only one undersecretary is eliminated or changed from one year to the next, the index takes a value close to 0 , which will depend on the total number of units. The higher the total number of units, the less weight each one will have in the index, naturally weighting its individual importance for overall bureaucratic change.

Because data exists for both countries at all three administrative levels in all sectors, the index is promising in terms of comparisons. The existence of organizational units is computed on the 1st of July each year to avoid transitional periods which usually take place at the beginning of the year in both cases.

The levels of change over time provide a first comparison of the degree of political control over the bureaucratic structure, interpreted as higher administrative adaptability capacity. 
Figure 1: Organizational chart changes in Argentina and Brazil 1990-2010

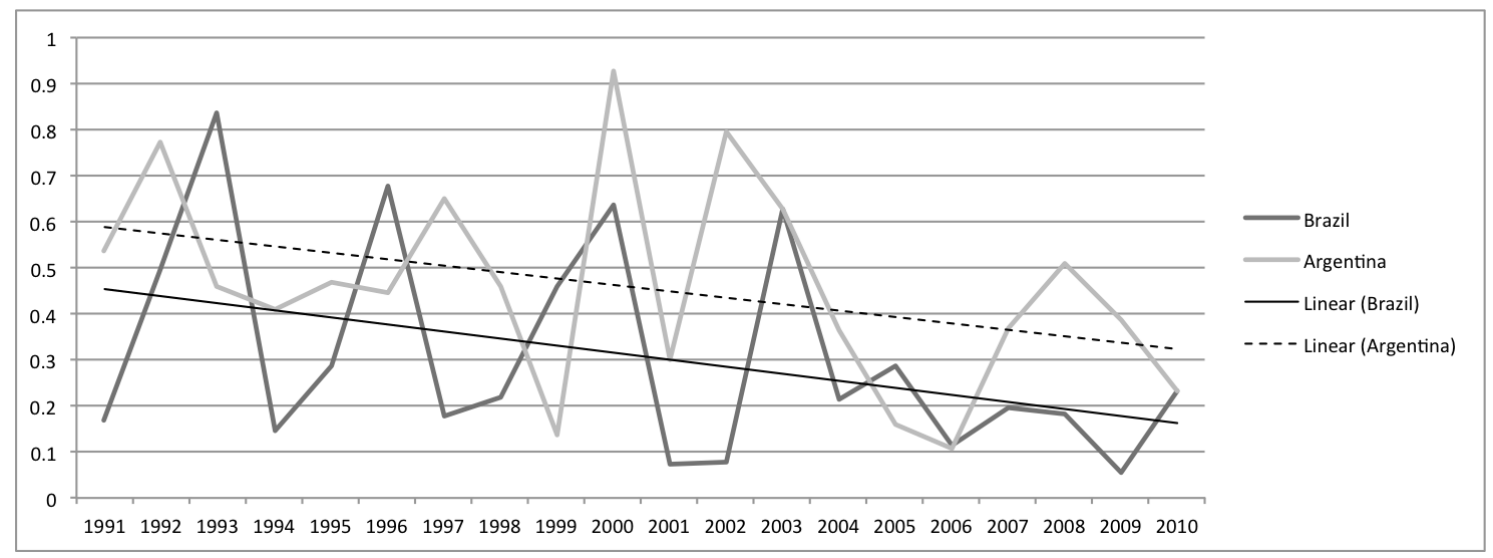

The graph shows several interesting findings. First, Argentina has on average 0.15 more points of organizational chart variation than Brazil, which represents around 30\% more changes on an annual basis. Also, in both countries variations are largely dependent on changes in presidential mandates and/or economic transformation episodes. Argentina experiences peaks during the massive privatization and state reform initiatives of the early nineties (1992), second generation state reforms (1996), changes in the governing party (2000 and 2002), the severe economic crisis of the early 2000s (2002), and to a lesser extent the arrival to power of Mr. Kirchner (2003) and Mrs. Kirchner (2008). In Brazil, the first peak corresponds to the aftermath of the impeachment of Collor de Mello and arrival of Franco (1993); the second to the arrival of Cardoso (1996); the third most likely to the aftermath of the devaluation and economic crisis of 1999 (1999/2000), and the last one to the arrival of Lula da Silva (2003). A third finding suggests that a clear downward trend can be registered in both cases. Interpreting this is not straightforward, but one possibility is that as these countries consolidate their democratic systems, the increase in political stability translates in less annual variation, and that transitions become smoother with time. This trend is more clear in the case of Brazil than Argentina.

A second analytical dimension of adaptability involves a slightly different conceptual angle, and measures the likelihood of variations in the organizational charts subject to turnovers of political principals. The next graph compares the countries in terms of the extent to which second and third level cabinet units (secretaries and undersecretaries) change depending on turnovers (TORs) of their corresponding ministers during the previous year. If, for example, two thirds of the lower level organizational units are changed from one 
year to the next, and of these, two thirds changed after a ministerial turnover, the bar in the graph would total 0.66, with the black portion (chart change with TOR) representing about 0.44 points and the grey one representing about 0.22 . The measure gives an accurate picture of the extent to which incoming leaders "appropriate" the bureaucratic structures in order to facilitate their mandates.

Figure 2: Organizational chart changes subject to political turnover in Argentina and Brazil 1990-2010

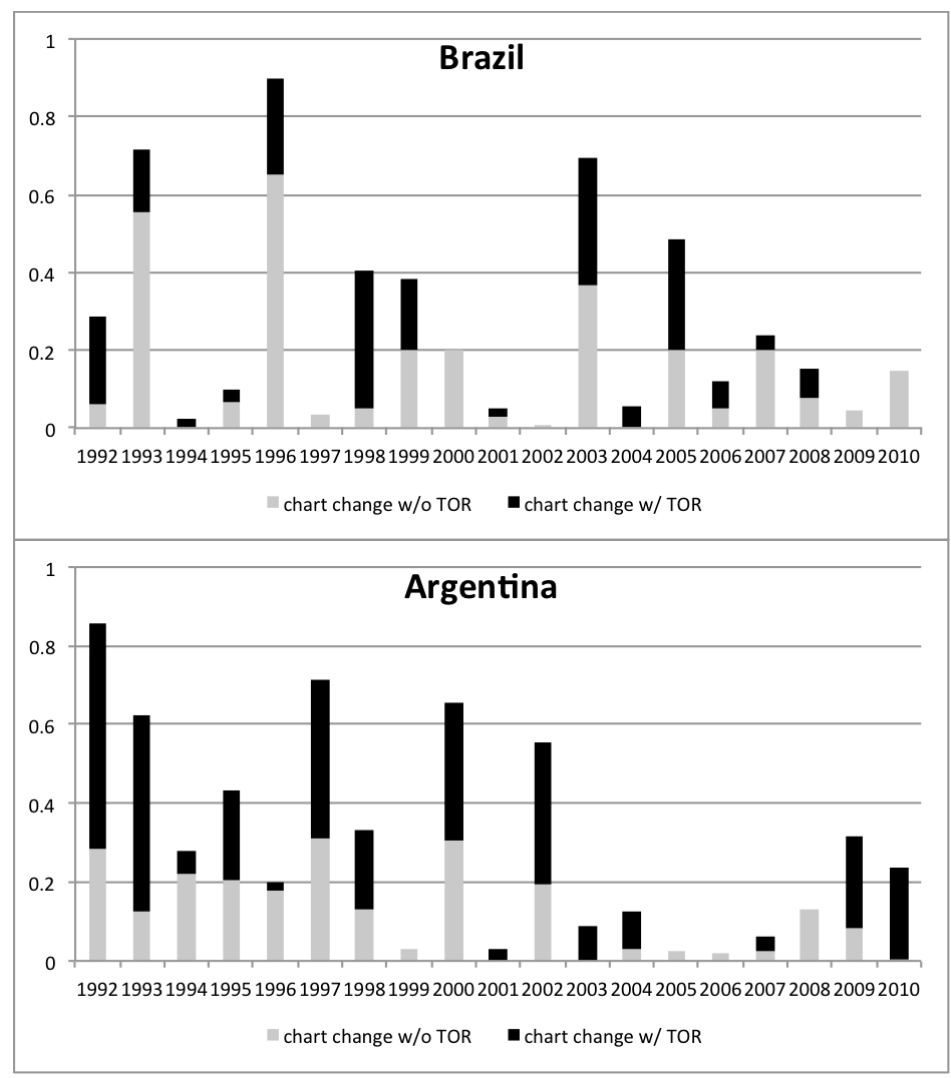

It is possible to observe that, with few exceptions, the proportion of organizational chart changes associated to turnovers is substantially higher in Argentina. To further test this statistically, I run a basic probabilistic analysis testing whether ministerial turnovers are significant in determining the probability of organizational chart change: 
Table 1: Probability of organizational chart change subject to political turnover in Argentina and Brazil (1991-2010).

\begin{tabular}{|c|c|c|c|c|c|}
\hline Year & Brazil & Argentina & Year & Brazil & Argentina \\
\hline \multirow[t]{2}{*}{1992} & $0.656^{* * *}$ & $0.421^{*}$ & 2002 & (omitted) & $0.357^{* * *}$ \\
\hline & $(0.001)$ & $(0.082)$ & & & 0.009 \\
\hline \multirow[t]{2}{*}{1993} & $-0.718^{* * *}$ & $0.778^{* * *}$ & 2003 & -0.065 & (omitted) \\
\hline & $(0.000)$ & $(0.000)$ & & 0.669 & \\
\hline \multirow[t]{2}{*}{1994} & (omitted) & $-0.682^{* * *}$ & 2004 & (omitted) & $0.580^{*}$ \\
\hline & & $(0.001)$ & & & 0.067 \\
\hline \multirow[t]{2}{*}{1995} & -0.296 & 0.045 & 2005 & 0.206 & (omitted) \\
\hline & $(0.120)$ & $(0.836)$ & & 0.163 & \\
\hline \multirow[t]{2}{*}{1996} & $-0.572^{* *}$ & $-0.970^{* * *}$ & 2006 & 0.202 & (omitted) \\
\hline & $(0.014)$ & $(0.001)$ & & 0.340 & \\
\hline \multirow[t]{2}{*}{1997} & (omitted) & 0.159 & 2007 & $-0.805^{* * *}$ & 0.205 \\
\hline & & 0.311 & & $(0.000)$ & 0.453 \\
\hline \multirow[t]{2}{*}{1998} & $1.049^{* * *}$ & $0.225^{*}$ & 2008 & -0.042 & (omitted) \\
\hline & $(0.000)$ & $(0.096)$ & & $(0.778)$ & \\
\hline \multirow[t]{2}{*}{1999} & -0.041 & (omitted) & 2009 & (omitted) & $0.548^{* * *}$ \\
\hline & $(0.803)$ & & & & 0.003 \\
\hline \multirow[t]{2}{*}{2000} & (omitted) & 0.072 & 2010 & (omitted) & $1.758^{* * *}$ \\
\hline & & 0.775 & & & 0.000 \\
\hline \multirow[t]{2}{*}{2001} & -0.150 & (omitted) & & & \\
\hline & 0.637 & & & & \\
\hline
\end{tabular}

Note: Probit estimations. Intercepts for each year are omitted.

These probit coefficients estimate increases or decreases in the probabilities that any subunit (secretaries and undersecretaries) is modified one year after a ministerial turnover occurs in the parent ministry. Data is therefore computed for the first time in 1992 based on turnovers between 1990 and 1991. Negative coefficients mean that increases in ministerial turnovers decrease the predicted probability of organizational chart change. Whenever all changes occur either with or without turnovers the estimations are naturally omitted. It is possible to find a positive and significant relationship seven times in Argentina, while only twice in Brazil throughout the period.

The overall picture suggests that although in both countries the centralized administration (cabinet offices) are largely adaptable, in Argentina this adaptability is substantially larger.

\subsection{Predictability}

Regarding bureaucratic predictability, I capture different patterns related to the behavior of independent agencies in the two countries. Discretionary political intervention in regulatory, administrative and coordination agencies is regarded as a major obstacle for policy predictability. The agencies in the 
database are autonomous in legal terms, meaning that they were granted the right to self-govern, enjoy fixed mandates for their governors and for the most part define their own budgets. Although governors are formally appointed by the executive, their duration in office is meant to be independent of any political concern.

The next histograms show for both countries the number of presidential appointments of independent agencies' governors in the days following the start of the respective presidential mandate, with 50-days gaps:

Figure 3: Argentina: appointment of agency leaders after new administration (days)
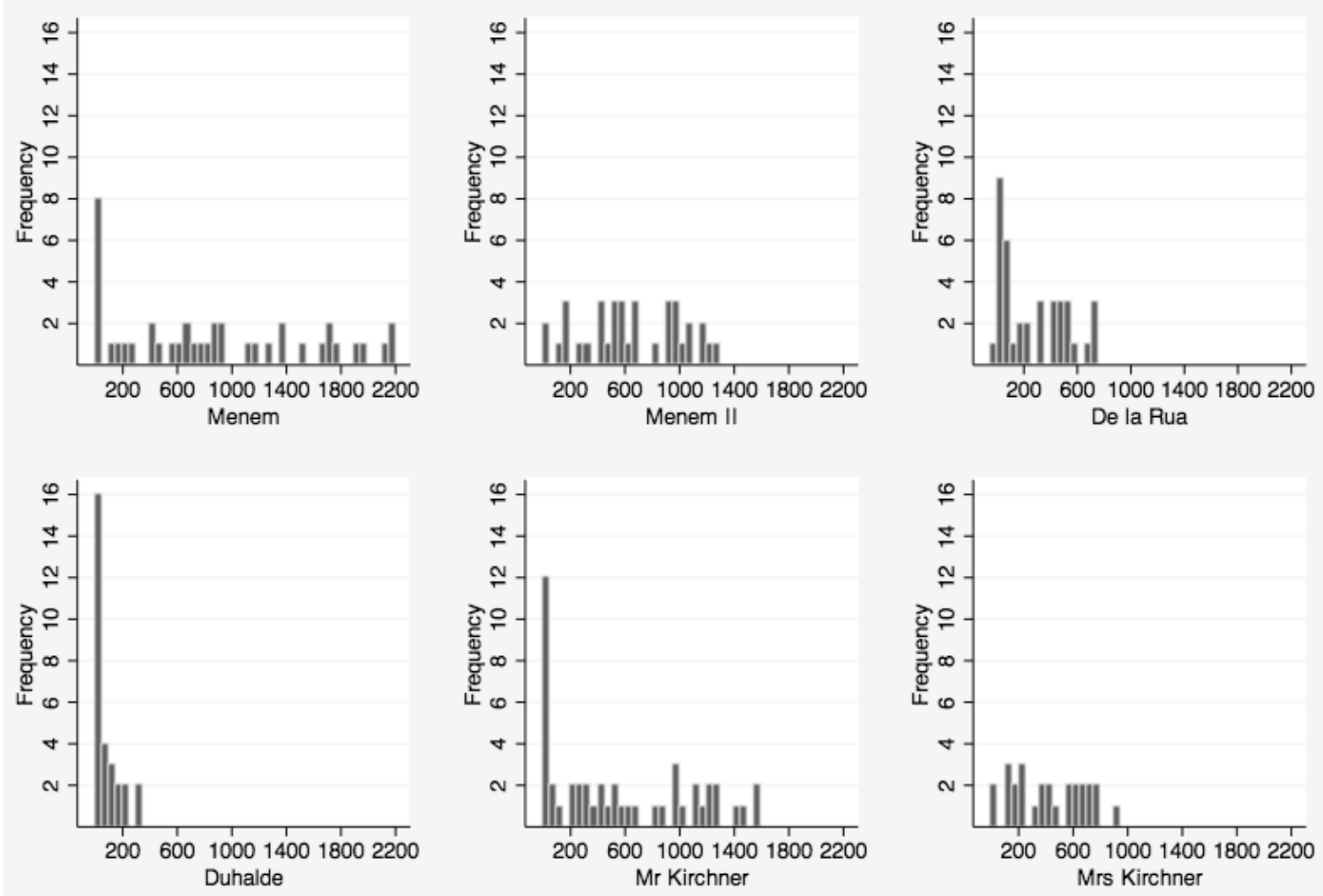
Figure 4: Brazil: appointment of agency leaders after new administration (days)
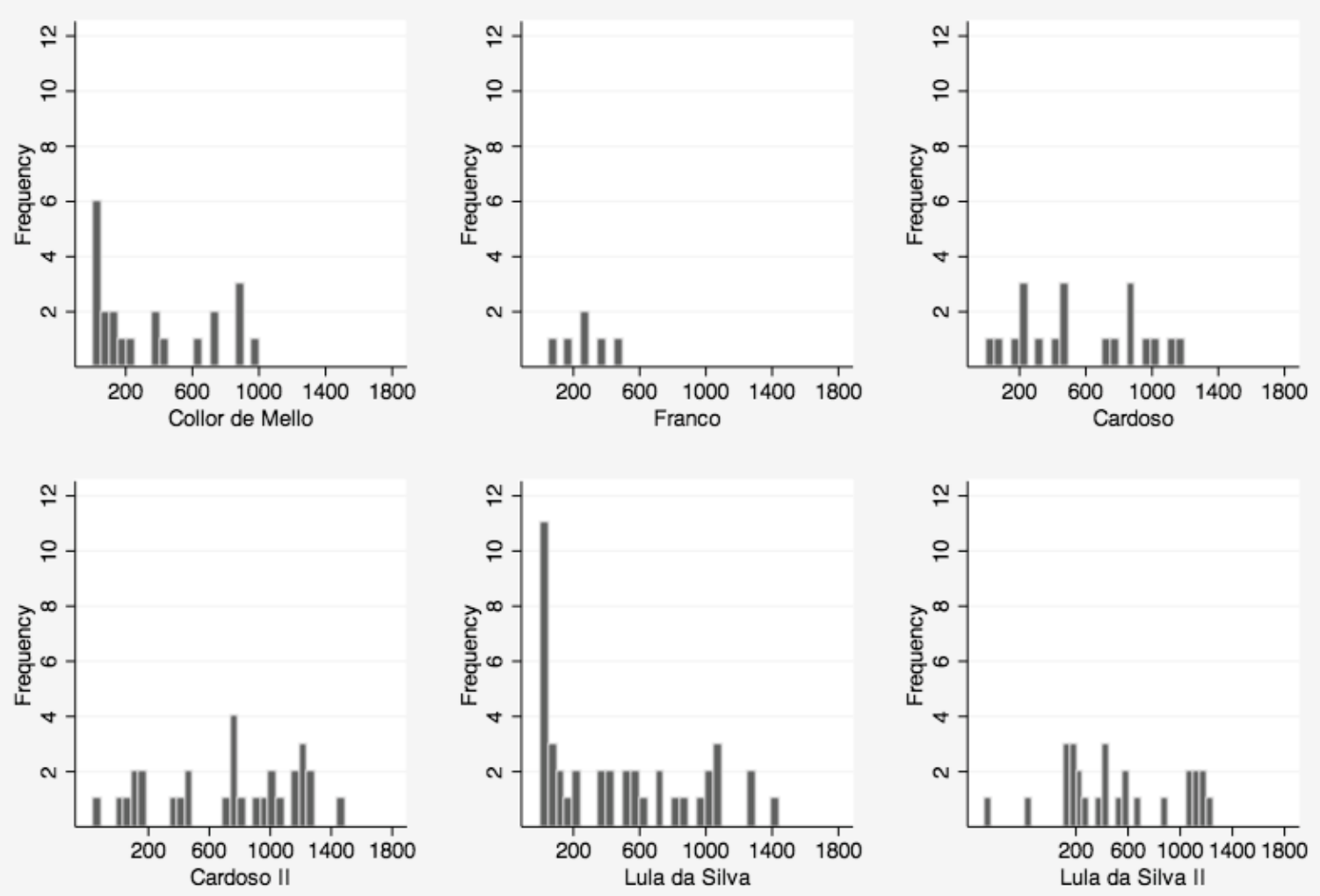

With the exception of the second Menem administration, and Mrs. Kirchner's mandate (which could arguably be considered a continuation of Mr. Kirchner's), in Argentina all new presidents have intervened agencies by appointing a large number of governors during their first 50 or 100 days in office. In Brazil the pattern differs more among presidencies. While Cardoso and Franco show a rather uniform distribution (signalling respect for independence), Lula da Silva and, to a lesser extent, Collor de Mello appointed a large number of governors at the start of their mandates compared to the following years.

Finally, some comparative patterns in the career paths of agency officials will illuminate further the overall dynamics of the relationship between bureaucrats and politicians, and give hints about both predictability and adaptability trends.

The next pie charts show some basic patterns of job mobility for those officials who were heads of independent agencies at some point during the 20 -year pe- 
riod. The first chart shows that while in Argentina $22 \%$ of all officials also took positions in the central government (either as minister, secretary or undersecretary of state), this percentage goes down to $13 \%$ in Brazil. Also, while in Argentina most of these officials were political apointees in the cabinet prior to their agency appointments, a minority followed this path in Brazil.

Figure 5: Career paths of agency leaders (1990-2010)

Argentina

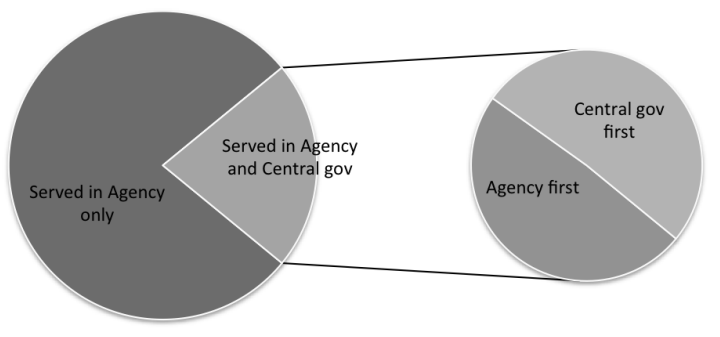

Brazil

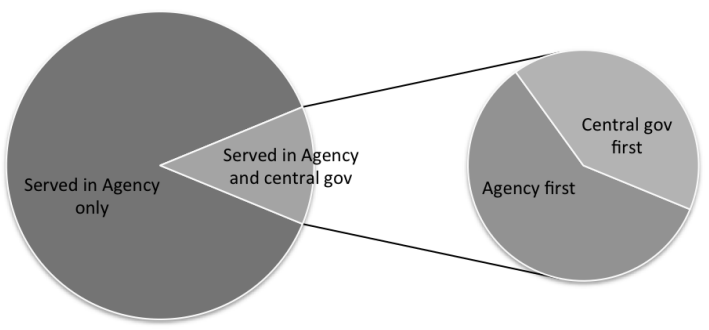

The second pie chart shows the presidencies under which these "political" agency leaders served: while in Argentina no particular presidency stands out, in Brazil more than a half served under Lula da Silva's administration.

Figure 6: Career paths of agency leaders II (1990-2010)

Argentina

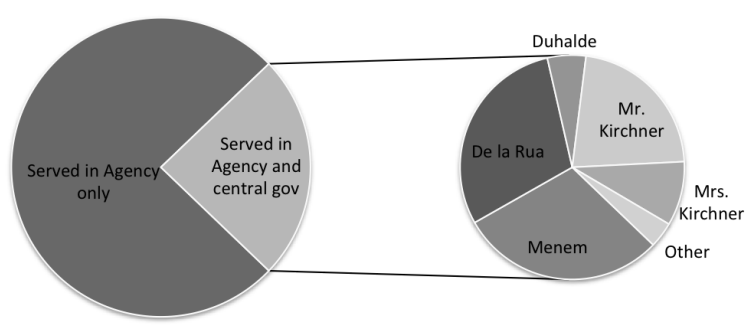

Brazil

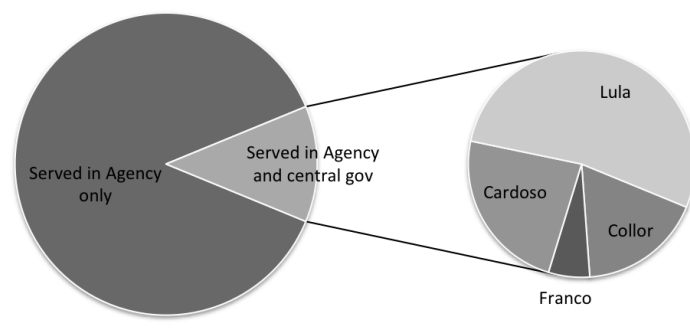

The overall picture suggests that Brazil relies on bureaucratic structures that 
are more prone towards stable regulation and predictability than Argentina, even though there is greater variance among presidencies. In the next section I delineate some of the political economy reasons behind this contrast, taking into account salient literature on institutions in the region.

\section{Adaptability and predictability: political econ- omy explanations}

Unraveling the general determinants of the contrast between the two countries in terms of bureaucratic structures involves a combination of historical, legal, political and economic factors. These include both political economy incentives for key relevant players, as well as historically-rooted traditions and customs that go back well beyond the period of the study.

\subsection{Congressional influence and oversight}

Over the last decade, Argentina has undergone a series of institutional changes affecting the level of political influence over both the centralized and descentralized administration. During the first post-democratic administrations of Alfonsin (1983-1989) and Menem (1989-1999) all reforms to the organizational chart of the administration were exclusively passed through congressional legislation. With the aim of favoring rapid state restructuring, the De la Rua administration (2000-2001) succeeded in having Congress delegate these powers to the executive in March $2001^{4}$, in the context of what was conceived as a third-generation administrative reform after the two waves of 1991/1992 and 1995/1996.

In spite of the fact that this reform failed to take off after a major governance crisis broke out, and that power delegation was meant to last a year only, administrative reform by decree was never reversed, not even well after the economic recovery of 2003/2004. These powers were largely profited by the subsequent administrations, both for rearranging cabinet charts, but also for deciding upon the structure of independent agencies.

The picture for Brazil is more mixed. The Brazilian Constitution of 1988 clearly defined the presidential and congressional powers regarding public administration reform. In its Article 61, section II grants the President the exclusive power to initiate legislation creating or terminating public offices, functions and positions in both the centralized and autarchic administration,

\footnotetext{
${ }^{4}$ Refers to Law 25411 of March 292001.
} 
as well as salary increases for public officials. These changes needed to be subsequently approved by both chambers of Congress with ordinary majorities. In 2001 an amendment was introduced ${ }^{5}$, allowing the president to reform federal structures by decree, as long as they do not involve an increase in expenses or the creation or termination of offices. Offices can be terminated by decree only in the case that they are left vacant. Article 37, section XIX, on the other hand, stipulates that only by means of a special law shall an autonomous agency be created, which limits presidential unilateral powers in this respect.

\subsection{Coalition government versus single party systems}

Party system configurations, as well as electoral laws are critical aspects in explaining the higher propensity of Brazil towards more predictable policymaking in comparison to Argentina.

Brazil is famous for its so called coalition presidentialism (Abranches 1988), largely determined by a proportional open-list representation system. This characteristic of the electoral system has led to all post-democratic administrations to govern by wide-coalition agreements, which often do not even reach the needed majorities to pass legislation in Congress. Collor de Mello governed through a conservative coalition of between two and five parties, that together totalled up to $44 \%$ of the seats in the lower house, while his party alone (PRN) only accounted for $5-8 \%$ of the seats. This weak position was partially responsible for his ousting of power in 1992. Franco, a centrist technocrat, ruled through a 5-party coalition for most of his mandate, with between 55 to $60 \%$ of the seats. Cardoso took over from Franco with a coalition of a similar leaning of between 3 and 5 parties, with 45 to $77 \%$ of the seats in the lower house. Lula da Silva led a leftist coalition of as much as 9 parties with majorities varying between $40 \%$ to $70 \%$ of the seats (Cheibub Figueiredo 2011; Praca, Freitas and Hoepers 2011). Thus, in spite of the fact that Brazilian presidents enjoy strong constitutional powers, when it comes to legislation they are obliged to strike deals with many different sectors.

Argentina, on the other hand, has had a bipartisan system with majoritarian single party governments alternating in power for most of its recent history, with a relative predominance of the Peronist party. This system was partially disrupted towards the late nineties, when for the first time a two-party coalition took power, to only last 24 months in office. After this, the party system resembled more the dominant type, with the Kirchnerist neo-peronist

\footnotetext{
${ }^{5}$ Amendment 32, September 112001.
} 
party enjoying an hegemonic position, while the opposition remained highly fragmented. This aspect of Argentine politics has largely turned the Congress into a 'rubber stamp' institution at certain points, and made it highly dependent upon intra-party discipline. One consequence of this has been the easy reform of structural bills and a generalized trend towards high intertemporal variation in policymaking.

\subsection{Civil service systems and traditions}

In spite of several attempts to centralize and professionalize public servants' careers, Argentina maintains a weak and fragmented system of human resource management in the public sector, largely determined by partisan concerns. Until the 40s, Argentina had no rules for civil service recruitment. After the Peron administrations (1945-1955) a few educational conditions were imposed, although the dominance of the Peronist party since then set the civil service on a path of wide scale partisan appointments as a double strategy to control policymaking and secure loyalties (Sikkink 1993, Scherlis 2013). In turn, at least three different administrative career systems have co-existed throughout the post-democratic years: a) meritocratically-elected elite corps; b) a wider institutionalized categorization system and c) mostly internationally-funded short-term consultants (e.g. Ozslak 1997).

Regarding the first, former Argentine president Raul Alfonsin founded in 1985 a public school that competitively recruited highly skilled aspirants to work for the public service. After graduation, these were meant to occupy key positions within the permanent bureaucracy and serve as coordination agents between ministries, while the executive could freely appoint and rotate them. These elite corps, named Governmental Agents Corps or AGs were recruited irregularly until 1993, when president Menem discontinued the program, in spite of which the already formed AGs continued to perform important roles across all different ministries. A wider and more inclusive approach to bureaucratic careers was undertaken through the National System for the Administrative Profession - SINAPA, introduced in 1992, which created an exhaustive salary scale and classifications for different functions and experience levels. SINAPA created incentives for professionalization but did not represent a unified system of cadre formation or fostered any espirit de corps. Also, recurrent recruitment freezes meant that the access to SINAPA was unequal. Finally, Argentina has had to resort to short-term contracting, a legal possibility introduced in 1995 by decree. Very often the funding came from external donor institutions, and contracts could be unilaterally terminated. This system reinforced the existing fragmentation, giving rise to a so called 'parallel bureaucracy' (Zuvanic and 
Iacoviello 2005; Zuvanic, Iacoviello and Rodriguez Gustá 2010).

The fragmentation can also be observed in the role and strength of cadre formation schools. In 1973 Argentina founded the Institute for Public Administration - INAP, designed as the main training school for public servants. Over time, however, it lost its autonomy and relevance, until it became a marginal and low-budgeted unit, used mostly at the convenience of the party in power. A similar attempt was made through the Institute of Government Economists, which opened in 1994 but dissolved in the year 2000.

Brazil, on the other hand, has the oldest formal civil service in Latin America (Grindle 2012). Judged to have the most consolidated Weberian administration and greatest level of continuity in the region, it was one of the first to establish a civil service career. The first recruitment exams took place in 1937, when president Getulio Vargas created the Department for Administrative Services or DASP, an undersecretary designed to monitor and unify the standards of the federal civil service. In addition, meritocratic systems of recruitment were foreseen by all constitutional texts since Vargas. Throughout the following decades, these efforts were implemented only in small areas of the state, that came to be known as pockets of efficiency such as the Central Bank, the National Economic Development Bank (BNDE), or public companies like Petrobras or CVRD for mining (Geddes 1986, Evans 1989). By the time Brazil re-entered democratic life in 1985, it combined meritocratic recruitment in pockets of efficiency with clientelistic recruitment in other areas (Gaetani and Heredia 2002). Over the last decades, nevertheless, Brazil's bureaucracy has also been open to New Public Management results-based principles, as well as representative bureaucracy principles, introducing quotas for women and underprivileged groups (Villoria Mendieta 2007).

Schools of public administration in Brazil have acquired greater relevance than those in Argentina. Specific sectors such as the military and the diplomatic corps count on specific training centers existing since the 1940s, such as the Air Force Academy (1941) for the former and Rio Branco Institute (1945) for the latter. Similar organizations were born during the 1970s, such as the Higher School of Financial Administration - ESAF (1973) and the Foundation for Administrative Development - FUNDAP (1974) (Pacheco 2000).

In 1952 the Brazilian School for Public Administration and Enterprise - EBAPE is founded by the Getulio Vargas Foundation, which in spite of being private, acquired a key role in training both public officers and businessmen, and was affiliated to a number of important international organizations. Apart from training, it produced relevant research and publications on public policies. A second important school is the National School of Public Administration ENAP, born in 1986, and its predecessor the FUNCEP NGO, born in 1980. 
The ENAP was modelled after the French National School of Administration - ENA, to become an elite cadre formation that would fill the ranks of the permanent bureaucracy, against the backdrop of Brazil's new democratic life. Although institutionalized entry contests were partially interrupted in the early 90s, the ENAP never stopped training the staff of the most insulated areas within the Brazilian state, such as the Treasury or the Central Bank. The ENAP re-gained momentum during the regulatory reforms of the mid 90 s.

\subsection{Regulatory reforms of the 1990s}

Several Latin American countries undertook state reform initiatives during the early 1990s. A common feature of these reforms was the establishment of independent regulatory agencies in the wake of liberal reforms, emulating similar transformations in Europe and the U.S. one decade earlier. Both Argentina and Brazil faced strong incentives to privatize public sector companies as a way to improve fiscal outcomes and attract foreign investors.

The hyper-inflation crisis of 1989, however, prompted Argentina to initiate reforms urgently, with the premise of dramatically downsizing the state, instead of foreseeing a more comprehensive and strategically-planned public management approach. A second wave of reforms took place in the mid 90s, also fostered by an economic crisis, the tequila crisis of 1995. These reforms included further lowering of public spending, along with increases in taxes meant to balance fiscal accounts. The organizational chart of the cabinet was dramatically altered and simplified, but once again financial results were at the center, while managerial aspects were marginally considered. Yet, the second reform lacked generalized support from different players, and run short in its scope, unable to meet its targets as well as the first one. Other reform attempts took place during the De la Rua government in 2000, that were unsuccessful and interrupted by the economic turmoil of 2001 / 2002. Although the initiatives introduced represented progressive improvements, the Argentine public administration remains largely neo-patrimonial -in particular at the provincial and municipal levels-, and barely prevents that party members and followers have privileged access to it (Scherlis 2013).

In Brazil, a profound reform started during the first Cardoso government with the aim of replicating the model of independent regulatory agencies following OECD guidelines in order to consolidate the permanent bureaucracy's career system. These reforms happened through a series of laws, but were also safeguarded as constitutional amendments, meaning that changes to the public service management need to reach constitutional status. 
Parallel to the consolidation of the permanent career system, the reforms also aimed at introducing New Public Management guidelines, such as resultsbased management, flexibility in contract termination for public servants, more autonomy for agencies and more accountable officials.

Regarding independent agencies in Brazil, these reforms stipulated that governor selection would happen through executive appointment based on expertise and subject to Senatorial approval. Governors would also enjoy fixed mandates, and normally be accompanied by a board of directors or assisted by advisory councils. The autarchy granted to agencies meant that they would enjoy vast decision-making powers and manage their own budgets. In order to enforce accountability, however, a widespread system of public consultations, public hearings and complaint mechanisms would fall on the agency (Mattos 2007). Cardoso's reforms also granted new momentum to public administration schools, such as in the case of the ENAP. A new wave of widespread training programs was implemented for all sectors of the civil service, as well as applied research increased (Pacheco 2000).

Other isolated measures enhanced the career system in Brazil. In the federal bureaucracy, $4 \%$ of public servants hold so called DAS positions (Direo e Assessoramento Superior), which make up the top-level bureaucracy. A few particular measures protect these positions: they are appointed by the President under recommendation of the Planning Ministry; they enjoy big salary incentives; and since 2005 it was established that $75 \%$ of lower level DAS and $50 \%$ of higher level DAS should be filled with career bureaucrats (Praça, Freitas and Hoepers 2011).

The reforms had profound and comprehensive results, and strengthened the bureaucratic career system (Gaetani and Heredia 2002). Although meritocratic recruitment was judged successful and is implemented in a wide scale (Longo 2005), on Lula's arrival, clashes occur between ministers and independent agencies (Mattos, 2007). In 2004 a bill was passed ${ }^{6}$ devolving procurement legislation and other regulatory aspects to ministers, signalling some degree of reversal of Cardoso's meritocratic reforms.

\subsection{Economic structure}

Argentina and Brazil enjoy overall similarities regarding their economic profiles, but also important differences. They both belong to the upper middleincome group of countries, with a GDP per capita of 18.400 U.S. dollars (PPP) for Argentina, versus 12.100 for Brazil (est. 2012). Yet, Brazil's economy is

\footnotetext{
${ }^{6}$ Law 3337.
} 
five times bigger in total GDP size, and its sectoral composition more diversified and developed.

In Argentina, basic agricultural products represent a $10.6 \%$ of the GDP; the industry accounts for $30.8 \%$, and the service sector for another $58.5 \%$. Manufactured goods make up about one third of all exports, half of which are agricultural-byproducts such as food processing, oils and biodiesel. Argentina's exports represent $21.8 \%$ of the GDP (World Bank 2011a).

In Brazil, the agricultural sector represents a $5.5 \%$ of the economy, industry another $27.5 \%$ and services $67 \%$, with manufactured goods making up $56 \%$ of all exports (World Bank 2011b). Brazil is the 7th economy worldwide, and has the second biggest industrial sector in the Americas, after the United States. Its industries range from automobiles, autoparts, steel and petrochemicals to computers, aircraft, and consumer durables. Its service sector is also highly diversified. In total, Brazil attracts six time higher inflows of foreign direct investment than Argentina. The domestic economy has enormous relevance and exports only represent a $11.9 \%$ of GDP.

A combination of active developmental plans in Brazil, along with a greater weight of industrial interests fostered a continuous feedback mechanism that shaped state structures in favor of these sectors. Sikkink (1993) provides a detailed description of the interplay between the bureaucracy and domestic economic interests in comparative perspective. While both countries had developmental plans during the 60s, president Kubitschek in Brazil relied on the more neutral administrative pockets of efficiency established earlier on, while Frondizi in Argentina attempted to build a parallel bureaucracy for this purpose only.

Frondizi, of the Intransigent Radical Union Party - UCRI needed to struggle with a permanent bureaucracy consisting mostly of Peronist loyalists who consolidated their positions during previous decades of Peronist dominance. When Frondizi called upon a number of committees to decide the strategic planning of foreign investment, the move was largely seen as a "parallel government" and failed to endure. Frondizi was ousted by a coup in 1962, four years after taking office. Some differences can be observed, for example, in the comparison of public entities in charge of coordinating and allocating resources for the productive sector, such as the BNDE in Brazil and the Banco Industrial - BI in Argentina. The BNDE enjoyed overall autonomy and had a long term perspective, with several international experts providing advice, such as the World Bank. The Argentine BI was less autonomous, and ended up favoring short-term credits and benefiting certain industries over others. Beneficiaries became dependent on short-term credits and opposed reforms to the bank. The turnover of directors was markedly high (Sikkink 1993). In 
other words, the interactions between politicians, bureaucrats and industrialists was more virtuous and intertemporally balanced in Brazil, which led to overall higher levels of regulatory predictability in this country.

\section{Conclusions}

In this article I have proposed a comparative study of the bureaucratic structures in Argentina and Brazil by moving beyond simplistic understandings of state structures and rather portraying bureaucracies as complex configurations of players, rules and organizational traits that often face contradicting incentives.

For this purpose I have built a novel and detailed database of organizational structures, appointments and agencification patterns at both the central and descentralized (autarchic) levels of the respective national bureaucracies for a 20 -year period. The use of objective and official data equivalent in both settings guarantees high-quality comparisons between the countries.

The main objective of the comparative endeavour has been to assess the bureaucratic technologies for policy adaptability and predictability existing in both countries, understanding technologies as mechanisms and resources by which the civil service is able to pursue one or the other, and where the resulting combination is here understood as the core matrix of policymaking.

A normative guideline is followed by which a comparatively more balanced and virtuous combination of adaptability and predictability represent higher levels of state capacity, without implying that state capacity is uniquely defined by these. In this sense, the article diverts from state capacity definitions that lean towards one in favor of the other. When linking bureaucratic technologies for adaptability and predictability, the first is related to a higher dominance of elected politicians vis-à-vis the permanent bureaucracy, while the opposite is the case for predictability.

In order to capture the administrative capabilities for policy adaptability and predictability I extract some particular empirical dimensions from the database, in some cases advancing novel tools and indexes to summerize the findings. To assess adaptability I examine the pace at which organizational charts are changed within the cabinet and its subunits, and the extent to which these changes respond strictly to officials' turnovers, as a strategy of "bureaucratic appropriation". For predictability, I test the extent to which independent agencies' governors were rotated in parallel to political changes, therefore capturing the overall level of correlation between political and per- 
manent bureaucracy's cycles. Finally, a good measure of effective separation between politics and bureaucracy is the assessment of the career paths of independent agencies' governors throughout the period, and whether they have occupied political positions at some point as well.

All in all, I find that Brazil has a bureaucracy that has come a longer way in building its predictability technologies, while the political coalition in power still retains high powers to reform the structures (and therefore adapt) when necessary. In the Argentine case, there is an overall dominance of the political representatives over the permanent bureaucracy, favoring adaptability over predictability. It remains for future discussion, however, to which extent these adaptability technologies are at the same time potential sources of policy volatility, and to which extent too much predictability is in reality policymaking rigidity or stalemate.

The reasons behind the resulting contrast between the countries are multiple and for the most part consistent with the institutional literature. Interestingly, and in line with traditional theories on veto players, a more fragmented decisional arena has led to a more stable policymaking matrix in Brazil, while a majority-driven decisional process has led to an intertemporally and intersectorally fragmented bureaucratic structure in Argentina. This can be observed in several aspects: a) the stronger congressional influence over the bureaucracy in Brazil; b) its highly proportional electoral system and its subsequent encouragement of inter-party agreements; c) the more important role played by the judiciary in enforcing administrative laws; d) the influence of an already existing professional bureaucracy when Brazil democratized in 1985. Also, state reforms of the 90 s were more comprehensive and strategically thought in the former country. Finally, Brazil's diversified economic structure is at the same time a cause and an outcome of a more independent bureaucracy that resisted political capture more successfully.

In sum, a diverse and plural political arena generated more incentives for a professional and stable public service in Brazil, while a more diversified economic structure has had a similar effect. It is also possible to observe that economic cycles affect the opportunities for administrative independence: while turmoil favors political reforms of the state apparatus, macroeconomic stabilization tends to favor more initiatives towards independence.

Counterintuitively, however, I also find that deeply rooted institutions do not completely explain the dynamics of state structures. Other factors such as the nature of leadership and political will seem to have played an important role in shaping reforms in both cases, most notably during the Cardoso administration in Brazil. There is plenty of evidence suggesting that Cardoso particularly pushed in the direction of civil service professionalization and 
higher predictability, even when, for example, most institutions were similar in all other administrations.

It is believed here that the quality of a country's public administration is the most important pillar of development. Although the search for highly capable bureaucracies has been a long-standing objective, as many scholars agree, we still know very little about how these processes are shaped in time. This article moves one step closer to this goal.

Yet, many challenges remain ahead. Comparative public administration studies are still in need for better and more precise empirical measures, so that they can illuminate more specific causal mechanisms. Also, the connections between development economics and in-depth studies of bureaucratic features and institutions in general need further complementarity, with quantitative and qualitative methods interacting virtuously instead of being mutually-exclusive. A renewed interest in comparative bureaucracies promises an eventful agenda for the future. 


\section{Appendix: Databases compilation and descrip- tion}

Each database (Argentina and Brazil) contains information on three main dimensions: the structure of the organizational chart of the central administration (ministries, secretaries, undersecretaries); the existence and characteristics of independent agencies; and the name of the civil servants that occupied the position of independent agency leader, minister, secretary or undersecretary.

\subsection{Organizational charts}

Data are taken from the national legislation of each country, searched through keywords related to administrative reform. For Brazil, the search engine used was planalto.gov.br, while for Argentina it was infoleg.gov.ar. Each distinct name of a unit in the three levels included (ministry, secretary or undersecretary) is computed as one observation. These units are coded with 1 if they existed on July 1st of every year from 1990 to 2010, and 0 otherwise. Whenever a unit changes names, then a new unit is created with the number 1, while the previous takes the value 0 . This coding overestimates real change in the organizational chart, but favors objectivity, as it minimizes the arbitrary coding of changes, mergers and terminations. Over the 20 years computed, there is a total of 1061 units in Argentina, and 1569 in Brazil.

\subsection{Independent Agencies}

The databases also lists the names of all autonomous agencies existing between 1990 and 2010 along with their dates of creation, their location in the organizational chart, as well as some additional information about their legal aspects. The databases compute whether each agency existed on July 1st of each year in the period, using the same criteria to compute changes as with the organizational chart. These agencies amount to 74 in Argentina and 46 for Brazil. These data are collected through the search of legislation with key terms related to autarchic bureaucratic entities (normally referred to as 'decentralized' in Argentina and Brazil) in planalto.gov.br and infoleg.gov.ar. 


\subsection{Appointments and career paths}

The databases also gather names and dates of appointment and removal of: heads of independent agencies; ministers, secretaries and undersecretaries. These total 1419 officials for Argentina and 1643 for Brazil. Each person is given a specific code, which allowed the building of an additional career path database for the people who held various of the above listed positions throughout the period. Data on appointments and removals was collected from the scanned and digital copies of both countries' daily official newsletters: the Boletin Oficial in Argentina and the Diario Oficial da Uniao in Brazil. Wikipedia and local newspapers served as complementary sources when necessary. 


\section{References}

Abranches, S. (1988). Presidencialismo de coalizão: o dilema institucional brasileiro. Dados, 31(1):5-38.

Alesina, A. and Tabellini, G. (2007). Bureaucrats or politicians? Part I: A single policy task. The American Economic Review, 97(1):169-179.

Alesina, A. and Tabellini, G. (2008). Bureaucrats or politicians? Part II: Multiple policy tasks. Journal of Public Economics, 92(3):426-447.

Bach, D. C. (2011). Patrimonialism and neopatrimonialism: comparative trajectories and readings. Commonwealth $\mathcal{E}$ Comparative Politics, 49(3):275294.

Bendor, J., Glazer, A., and Hammond, T. (2001). Theories of delegation. Annual review of political science, 4(1):235-269.

Bertelli, A. and Feldmann, S. E. (2007). Strategic appointments. Journal of Public Administration Research and Theory, 17(1):19-38.

Brans, M. (2003). Comparative public administration: from general theory to general frameworks. Handbook of Public Administration, Londres, Sage, pages $424-439$.

Calvert, R., McCubbins, M., and Weingast, B. (1989). A theory of political control and agency discretion. American journal of political science, 33(3).

Carpenter, D. P. (2001). The forging of bureaucratic autonomy: Reputations, networks, and policy innovation in executive agencies, 1862-1928. Princeton University Press.

Cheibub Figueiredo, A. (2011). Government coalitions in brazilian democracy. Brazilian Political Science Review, 1(2):182-216.

Christensen, J. (2010). Public Interest Regulation Reconsidered: From capture to credible commitment. In Regulation at the Age of Crisis. ECPR Regulatory Governance Standing Group, 3rd Biennial Conference, University College, Dublin, June.

Cingolani, L. (2013). The State of State Capacity: a review of concepts, evidence and measures. UNU-Merit Working Paper Series 2013-053.

Cingolani, L., Thomsson, K., and de Crombrugghe, D. (2013). Minding Weber more than ever? The impacts of State Capacity and Bureaucratic Autonomy on development goals. UNU-Merit Working Paper Series 2013-052. 
Dahlström, C., Lapuente, V., and Teorell, J. (2010). Dimensions of bureaucracy. A cross-national dataset on the structure and behavior of public administration, volume 13. QoG Working Paper Series.

Dahlstrom, C., Lapuente, V., and Teorell, J. (2012). The merit of meritocratization politics, bureaucracy, and the institutional deterrents of corruption. Political Research Quarterly, 65(3):656-668.

Dixit, A. K. (2006). Predatory States and Failing States: An Agency Perspective. Center for Economic Policy Studies, Princeton University.

Dixit, A. K. (2010). Democracy, autocracy and bureaucracy. Journal of Globalization and Development, 1(1).

Evans, P. B. (1989). Predatory, developmental, and other apparatuses: A comparative political economy perspective on the third world state. Sociological Forum, 4(4):561-587.

Evans, P. B. (1995). Embedded Autonomy. Princeton University Press.

Fukuyama, F. (2012). The strange absence of the state in political science. The American Interest. Blog entry, February 2012.

Gaetani, F. and Heredia, B. (2002). La economia política de la reforma del servicio civil en brasil: los años de cardoso. Technical report, Inter-American Development Bank.

Gailmard, S. (2007). Slackers and zealots: Civil service, policy discretion, and bureaucratic expertise. American Journal of Political Science, 51(4):873889 .

Gailmard, S. and Patty, J. W. (2012). Formal models of bureaucracy. Annual Review of Political Science, 15:353-377.

Geddes, B. J. (1986). Economic development as a collective action problem: individual interests and innovation in Brazil. University of California, Berkeley.

Gilardi, F. (2008). Delegation in the regulatory state: independent regulatory agencies in Western Europe. Edward Elgar Publishing.

Gilardi, F. and Maggetti, M. (2011). The independence of regulatory authorities. In Levi-Faur, D., editor, Handbook on the Politics of Regulation. Edward Elgar Publishing.

Grindle, M. S. (2012). Jobs for the Boys: Patronage and the State in Comparative Perspective. Harvard University Press. 
Haggard, S. and McCubbins, M. D. (2001). Presidents, parliaments, and policy. Political economy of institutions and decisions. Cambridge: Cambridge University Press.

Hammond, T. H. and Knott, J. H. (1996). Who controls the bureaucracy?: Presidential power, congressional dominance, legal constraints, and bureaucratic autonomy in a model of multi-institutional policy-making. Journal of Law, Economics, and Organization, 12(1):119-166.

Hanretty, C. and Koop, C. (2009). Measuring regulators statutory independence. APSA annual meeting paper.

Hanson, J. and Sigman, R. (2011). Measuring state capacity: Assessing and testing the options. APSA annual meeting paper.

Heclo, H. (1977). A government of strangers: Executive politics in Washington. Brookings Institution Press.

Hendrix, C. S. (2010). Measuring state capacity: Theoretical and empirical implications for the study of civil conflict. Journal of Peace Research, $47(3): 273-285$.

Hout, W. (2007). Development under patrimonial conditions: Suriname's state oil company as a development agent. Journal of Development Studies, 43(8):1331-1350.

Huber, J. D. and Lupia, A. (2001). Cabinet instability and delegation in parliamentary democracies. American Journal of Political Science, 45(1):18-32.

Huber, J. D. and Shipan, C. R. (2002). Deliberate discretion?: The institutional foundations of bureaucratic autonomy. Cambridge University Press.

Iyer, L. and Mani, A. (2012). Traveling agents: political change and bureaucratic turnover in india. Review of Economics and Statistics, 94(3):723-739.

Jordana, J., Levi-Faur, D., and i Marín, X. F. (2011). The global diffusion of regulatory agencies channels of transfer and stages of diffusion. Comparative political studies, 44(10):1343-1369.

Kohli, A. (2004). State-directed development: political power and industrialization in the global periphery. Cambridge University Press.

Lapuente, V. (2007). A Political Economy Approach to Bureaucracies. Doctoral dissertation, University of Oxford.

Lapuente, V. and Nistotskaya, M. (2009). To the short-sighted victor belong the spoils: Politics and merit adoption in comparative perspective. Governance, 22(3):431-458. 
Leonard, D. K. (2010). pockets of effective agencies in weak governance states: Where are they likely and why does it matter? Public Administration and Development, 30(2):91-101.

Levi-Faur, D. (2005). The global diffusion of regulatory capitalism. The Annals of the American Academy of Political and Social Science, 598(1):12-32.

Longo, F. (2004). Mérito y flexibilidad: la gestión de las personas en las organizaciones del sector público, volume 102. Editorial Paidós.

Longo, F. (2005). Diagnóstico institucional comparado de sistemas de servicio civil: Informe final de síntesis. Technical report, Inter-American Development Bank.

Majone, G. (1994). The rise of the regulatory state in europe. West European Politics, 17(3):77-101.

Majone, G. (1997). From the positive to the regulatory state: causes and consequences of changes in the mode of governance. Journal of public policy, 17(02):139167.

Mattos, P. T. (2007). The regulatory reform in Brazil: new regulatory decisionmaking and accountability mechanisms. University of San Andres - New York University Law School, Buenos Aires.

McCubbins, M. D., Noll, R. G., and Weingast, B. R. (1987). Administrative procedures as instruments of political control. JL Econ. \& Org., 3:243.

McCubbins, M. D., Noll, R. G., and Weingast, B. R. (1989). Structure and process, politics and policy: Administrative arrangements and the political control of agencies. Virginia Law Review, pages 431-482.

Médard, J. F. (1991). L'Etat néo-patrimonial en Afrique noire. États d'Afrique noire. Formations, mécanismes et crise, pages 323-353.

Melo, M. A., Pereira, C., and Werneck, H. (2010). Delegation dilemmas: Coalition size, electoral risk, and regulatory governance in new democracies. Legislative Studies Quarterly, 35(1).

Moe, T. M. (1985). The politicized presidency. In Chubb, J. E. and Peterson, P. E., editors, The new direction in American politics. Brookings Institution, Washington D.C.

Neustadt, R. E. (1960). Presidential power. Wiley New York.

North, D. C., Wallis, J. J., Webb, S. B., and Weingast, B. R. (2012). In the shadow of violence: Politics, economics, and the problems of development. Cambridge University Press. 
Oszlak, O. (1997). The argentine civil service: An unfinished search for identity. Research in Public Administration, 5:267-326.

Pacheco, R. S. (2000). Escolas de governo: tendências e desafios. Enap - Brasil em perspectiva comparada. Revista do Serviço Público, 51(2).

Praça, S., Freitas, A., and Hoepers, B. (2011). Political appointments and coalition management in brazil, 2007-2010. Journal of Politics in Latin America, 3(2).

Rasul, I. and Rogger, D. (2013). Management of bureaucrats and public service delivery: Evidence from the nigerian civil service. Working Papers, University College London.

Roll, M. (2011). The State that Works: Pockets of effectiveness as a perspective on stateness in developing countries. Technical report, Arbeitspapiere des Instituts fur Ethnologie und Afrikastudien der Johannes GutenbergUniversitat Mainz.

Roll, M. (2014). The politics of public sector performance: pockets of effectiveness in developing countries. Routledge.

Scartascini, C., Stein, E., and Tommasi, M. (2010). How Democracy Works: Political Institutions, Actors, and Arenas in Latin American Policymaking. David Rockefeller Center for Latin American Studies.

Scherlis, G. (2013). Designaciones y organización partidaria: el partido de redes gubernamentales en el peronismo kirchnerista. América Latina Hoy, 62:47-77.

Sikkink, K. (1993). Las capacidades y la autonomía del estado en brasil y la argentina. un enfoque neoinstitucionalista. Desarrollo Económico, pages $543-574$.

Tsebelis, G. (1995). Decision making in political systems: Veto players in presidentialism, parliamentarism, multicameralism and multipartyism. British journal of political science, 25(03):289-325.

Tsebelis, G. (2002). Veto players: how political institutions work. Princeton University Press.

Villoria Mendieta, M. (2007). El servicio civil de carrera en latinoamérica: diagnóstico, causas y propuestas. INAP, Argentina.

Von Soest, C. (2009). Informal institutions compared-persistence and change of neopatrimonialism in various world regions. In APSA 2009 Toronto Meeting Paper. 
Wade, R. (2010). After the crisis: Industrial policy and the developmental state in low-income countries. Global Policy, 1(2):150-161.

World Bank (2011a). Argentina at a glance. Technical report, Development Economics LDB database.

World Bank (2011b). Brazil at a glance. Technical report, Development Economics LDB database.

Yesilkagit, K. (2004). Bureaucratic autonomy, organizational culture, and habituation politicians and independent administrative bodies in the Netherlands. Administration \& Society, 36(5):528-552.

Yesilkagit, K. and Christensen, J. G. (2010). Institutional design and formal autonomy: Political versus historical and cultural explanations. Journal of Public Administration Research and Theory, 20(1):53-74.

Zuvanic, L. and Iacoviello, M. (2005). El rol de la burocracia en el pmp en américa latina. Washington: Inter-American Development Bank.

Zuvanic, L., Iacoviello, M., and Rodríguez Gustá, A. L. (2010). The weakest link: the bureaucracy and civil service systems in latin america. $C$. Scartascini, Ernesto Stein and Mariano Tommasi, How Democracy Works: Political Institutions, Actors, and Arenas in Latin American Policymaking, pages 147-176. 


\title{
Chapter 4
}

\section{The Anti-corruption Office of Argentina: Momentous, idle... and momentous again?}

\author{
Luciana Cingolani*
}

\begin{abstract}
Over the past 20 years a wave of anti-corruption agencies (ACAs) were put in place worldwide as key mechanisms to prevent and counterbalance corruption. Yet their performance has been deemed disappointing by most donors and experts. This article scrutinizes the work of the Argentine Anti-Corruption Office since its creation in 1999, by placing the focus on the critical junctures that set the agency on particular performance paths, and their implications for the agency's overall capacity. It applies process tracing and draws on official documents, media content and in depth-interviews with the ultimate goal of assessing how (non) reversible certain strategies and institutional mechanisms used to undermine its autonomy are, as well as the successful features that persisted over time. The work aims to contribute to the understanding of the many nuances these agencies face, and to provide a broader perspective on how to judge their success or failure.
\end{abstract}

\section{Introduction}

Following the success cases of the Independent Commission Against Corruption (ICAC) in Hong Kong, and Singapore's Corrupt Practices Investigations Bureau (CPIB) in the 1970s, international organizations and experts on transparency sponsored the incorporation of anti-corruption agencies (ACAs) as key tools in the anti-corruption fight.

Towards the late 1990s, a wave of ACAs sprung across all world regions. The creation of these agencies was boosted by regional organizations such as the

*Maastricht Graduate School of Governance - UNU-Merit. Email: cingolani@ merit.unu.edu 
Organization of American States (OAS), the African Union and the European Union, as well as international players like the United Nations, the World Bank, the IMF and the OECD among others.

ACAs' importance was further underpinned by the 2005 United Nations Convention Against Corruption (UNCAC), which foresees in its Article 6 the creation of preventive anti-corruption bodies at the national level, vested with the 'necessary independence' in order to implement anti-corruption policies and disseminate knowledge about the prevention of illicit activities. Soon after being in place, however, donors, practitioners and scholars have judged their performance as highly insufficient, given the objectives that were first set when created.

This article analyses the characteristics and evolution of the Argentine AntiCorruption Office (ACO), created in 1999, with the purpose of assessing its strengths and weaknesses from a dynamic perspective, and a multiplicity of political economy dimension. It looks at the critical junctures that set ACO on particular performance paths, and provides a comprehensive analysis of a) the strategies and larger institutional configurations that determine these paths, and b) the difficulty of reversing a particular performance path based on its determinants. This allows to move beyond the analysis of immediate performance alone, and look at more structural levels of overall agency capacity.

The Argentine agency is selected because it represents a young organization embedded in an overall adverse governance context, encountering high variance of performance throughout its existence. Also, the work helps bridge a substantial gap in the literature on Latin American ACAs, as well as highlight the importance of subtle mechanisms hindering agency independence in a challenging governance context. The findings suggest a steady decline in ACO's performance, although a slightly more optimistic picture emerges when overall potential is assessed on the basis of more structural aspects.

The next section provides an overview of the literature on ACAs, and the multiple determinants of their performance. Section 3 lays out the main analytical and methodological framework used. Section 4 provides a brief description of the Argentine Anti-Corruption Office and its performance, while section 5 analyses the critical junctures in time affecting ACO's work. The final section offers some concluding thoughts on the Argentine agency and ACAs more generally. 


\section{Anti-Corruption Agencies in the academic dis- course}

The academic literature on ACAs is rather compact and largely driven by the debates and strategies pursued by international donors and practitioners. As ACAs became central devices in the anti-corruption fight following the success cases of Hong Kong and Singapore, donors promulgated their adoption by national governments starting in the late 1990s. After observing their performance for only a few years, a large bulk of scholarly works dedicated efforts to the analysis of the necessary and sufficient conditions for ACAs' success across different governance contexts and world regions (Doig 1995; Pope and Vogl 2000; Meagher 2005; Doig, Watt and Williams 2006 2007; Shah 2007). Later on, authors tended to focus on the various reasons behind the many difficulties these agencies faced, some of which played a crucial role in undermining the initial high expectations (e. g. De Sousa 2010).

A few works have studied actors' motivations as well as contextual spontaneous reasons behind the creation of ACAs. Smilov (2009) sees ACAs as discourse-controlling devices by which governments gain leverage within the anti-corruption community. Meagher (2005) stresses that ACAs are very frequently the consequence of media scandals. Doig, Watt and Williams (2005) address governments' motivation of exposing the crimes from previous administrations, while Dionisie and Cecchi (2008) argue that the EU accession process served as a strong incentive for European countries to set up these agencies.

Regarding performance, many of the earlier works placed high expectations on ACAs. Meagher (2005), for example, argues that ACAs can be successful in moderately democratic contexts, and that they are able to reduce overall incentives for corruption by centralizing all existing information and intelligence about related events, as well as integrate all anti-corruption players and solve coordination problems. After numerous reports about failures and constraints, later works highlight the importance of lowering expectations and relativizing achievements (Doig, Watt and Williams 2006; De Sousa 2010).

Numerous works have developed frameworks to discuss and assess ACAs' performance in comparative perspective (Doig, Watt and Williams 2005; Meagher 2004; Johnsøn, Hechler, de Sousa and Mathisen 2011). Among the donor community, UNDP (2011) released a practitioner's guide to evaluate and strengthen the capacity of ACAs. In spite of the many performance evaluations carried out, Johnsøn, Hechler, de Sousa and Mathisen (2011) reveal a generalized lack of rigour in the area. In a meta-analysis of 13 evaluations, 
they find that the majority does not inform of any specific methodology beyond document analysis and interviews, and that clear performance indicators are missing, as well as explanations about the sources used. They conclude that these findings undermine the validity and credibility of ACAs performance assessments.

Qualitative comparative and in-depth case methodologies dominate the field. Most scholars have presented low-n case comparisons of agencies' organizational and contextual features across regions. Meagher (2004 2005) analyses ACAs in five moderately democratic settings; Doig, Watt and Williams (2005, 2006) compare five ACAs in sub-Saharan economies; Quah (2008) follows with four Asian countries; while Batory (2012) compares three Eastern European countries. Others have pursued in-depth single-case studies, such as Head (2012) on Australia, or De Speville on Hong Kong (2010).

Few works have favored larger-n comparisons (UNDP 2005; Charron 2008; Johnsøn, Hechler, de Sousa, Mathisen 2011), while statistical analysis has been scarce and mostly exploratory (e. g. Charron 2008). UNDP (2005) covers 14 ACAs in Africa, South East Asia, the Pacific and Eastern Europe. Charron (2008), in turn, looks at variations in 18 ACAs in Eastern and Central Europe, Africa, Latin America and South East Asia. Based on a survey of ACAs' directors and senior personnel, the article finds that stronger agencies in terms of autonomy, enforcement capacity, transparency, inter-agency cooperation and prevention are more closely associated with changes in corruption perceptions after the setup of the agencies.

The literature is in general consistent in terms of the factors that improve ACAs' position and performance, although some debates exist. Great importance is given to the overall governance context in which these agencies are embedded, as well as the support from changing governments (Doig, Watt and Williams 2007; Shah 2007; Head 2012; Batory 2012). Also the supporting role of complementary institutions such as prosecutors, general auditors, ombudsmen and civil service commissions acquires particular relevance in the literature (Meagher 2005; UNDP 2005; Head 2012). Meagher (2005) highlights the importance of ACAs' strategic focus when defining objectives, along with the corresponding powers and resources allocated. From a broader perspective, the author underlines the importance of political and macroeconomic stability levels, as well as the perceived political gains that stem from the anticorruption fight. Other dimensions are regarded as important: operational autonomy and leadership (Batory 2012), the role of donors and the format of their interventions (Doig, Watt and Williams 2006 2007), and agencies' past performance (Doig, Watt and Williams 2005).

In some cases the legal safeguards in terms of independence from politics 
becomes essential (e.g. Pope and Vogl 2000; UNDP 2005); while in others this is given only relative importance (e. g. Meagher 2005; Hussmann, Hechler and Penailillo 2009; Batory 2012). A few articles discuss what the ideal scope of agencies should be: some in favor of strategic long-term reform (Doig 1995) or prevention in general (Doig 2012), while others endorse a more encompassing role, where investigations and prosecutions form the core of the agency's work (Langseth 2001 in Meagher 2005). Parallel to this, scholars and practitioners have debated whether ACAs should replicate the single-agency model that concentrates prevention, prosecution and awareness roles, as pioneered in the experiences of Hong Kong and Singapore (Meagher 2005), or a multiple-agency model, in which these tasks are differentiated, therefore avoiding some of the weaknesses of the single-agency model (Doig, Watt and Williams 2006).

The literature also offers some insights regarding the inhibitors that prevent agencies from pursuing their objectives. Doig, Watt and Williams $(2005,2006)$ find a lack of congruence between the motivations and capacities of governments, donors and ACAs. They argue that ACAs' failure is normally connected to the way these are funded by donors, with most resources going to high visibility activities, while the more permanent organizational infrastructure is less favored. Also, donors can be detrimental by pushing for immediate results that hinder medium-term agency survival and performance. These authors suggest that donors would contribute better through a more passive 'hands off' approach to capacity building. Similarly, Doig, Watt and Williams (2007) highlight the different cycles governments and donors face: while donors are overall stable, local conditions can change easily and frequently, and earlier local support for ACAs can disappear as easily. Apart from some commonly acknowledged internal and external difficulties that ACAs face, De Sousa (2010) highlights some unintended mistakes in the initial setup of the agency, such as not giving enough attention to the format chosen, the management strategy or the adequacy of the financial resources in relation to the agency's goals. These are observed to have strong impacts on ACAs' subsequent development.

Given that the systematic study of ACAs is very recent, the literature leaves some important lacunae. Although academic research on corruption in Latin America is rich, comparative or single case studies on ACAs in particular are very scarce. Also, scholars have favored cross-sectional comparisons, instead of looking at ACAs trajectories and the critical factors that have set agencies on a particular performance path over time. In line with this, scholars have not assessed how reversible ACAs paths are in the context of different internal and external political economy conditions. The present contribution aims to provide new ideas in these respects. 


\section{Analytical framework}

This article examines the evolution of ACO's work between 1999 and 2012 by placing the focus on a series of institutional and organizational dimensions affecting its performance and capacities. These dimensions are derived from the previous literature review, where different authors have stressed the importance that one or more of these have for the proper functioning of agencies:

- Legal mandate (Pope and Vogl 2000, UNDP 2005, Charron 2008, De Sousa 2010): refers to the agency's legal mandate and powers to pursue its tasks independently from the ruling coalition. It is determined by the original powers granted to the agency, usually in the form of a parliamentary law that defines agency characteristics such as how its head is appointed and removed, whether it can decide upon its own budget, and how decisions are made regarding its internal functioning.

- Operational autonomy and resources (Meagher 2005, De Sousa 2010): these are the endowments in terms of budget, personnel, technical equipment and resources in general with which the agency carries out its duties. Regardless of its legal powers, these elements determine much of the de facto autonomy the agency achieves.

- Political support (Doig, Watt and Williams 2005 2007, Shah 2007, Head 2012, Batory 2012): is the extent to which the ruling coalition at the time is sympathetic towards the agency's work on anti-corruption, and whether it attempts to develop strategies to undermine its performance. This support is usually captured through the visible and less visible decisions the coalition makes regarding the agency, how it selects its leader (when appropriate) and the speed and will with which it reacts to the agency's initiatives.

- Leadership (Batory 2012): refers to the expertise, dynamism and will of the agency's head. ACAs can either count on politically-sided leaders or more independent experts on anti-corruption. The quality of the leadership determines the agency's capacity to overcome potential attacks, adapt to new context and innovate when the opportunity arises.

- Role of complementary institutions (Meagher 2005, Charron 2008): is the environment in which ACAs are institutionally embedded, and is determined by the existence and support coming from organizations that investigate similar illicit activities within the polity. These include anticorruption courts and attorneys within the Judiciary, but also other 
independent executive agencies in charge of auditing administrative processes.

- Links with international players and NGOs (Doig, Watt and Williams 2006 2007, Dionisie and Cecchi 2008): is the density of the networks developed with international donors, parallel agencies in other countries, international NGOs and local organizations concerned with anticorruption issues. These links help disseminate the agency's work as well as acquire new critical knowledge and resources.

- Agency performance (Meagher 2005, Doig, Watt and Williams 2006, UNDP 2011, Johnsøn, Hechler, de Sousa and Mathisen 2011): is the main outcome variable being analyzed, as a function of all other dimensions. It is here captured as the end-of-year results achieved by the agency in terms of file status: how many anti-corruption complaints are resolved and how (whether they are derived to the justice system or other organizations, or rather closed down or rejected).

Methodologically, the article uses process tracing in order to capture the socalled 'critical junctures' around these dimensions, whenever particular events have a strong impact on ACO's work later on. Process tracing enables the within-case exploration of the historical factors that explain temporally bound phenomena (Bennett 2008). This methodology proceeds both in an inductive and deductive manner, in this case by contrasting the evolution of ACO against scholarly theories on ACAs, as well as deriving general thoughts from the particularities of the Argentine case.

Process tracing is a key methodology for uncovering and analyzing 'critical junctures' (Capoccia and Kelemen 2007). The study of critical junctures in political science was first systematically developed by Collier and Collier (1991) in their study of labor movements in Latin America, and later permeated throughout several area studies and sub-disciplines ${ }^{1}$. It is embedded in the more general category of historical institutionalism (Thelen 1999), in particular as a complement of studies on political path-dependency (e. g. Pierson 2000; Peters et al. 2005; Page 2006) and incrementalism (Streeck and Thelen 2005). Critical junctures are here understood as "relatively short periods of time during which there is a substantially heightened probability that agents' choices will affect the outcome of interest" (Capoccia and Keleman 2007: 348).

The study of critical junctures is commonly applied to long-term macrohistorical studies, where periods of stability can be adequately observed. Yet,

\footnotetext{
${ }^{1}$ See Capoccia and Kelemen (2007) for an insightful analysis of the concept and its methodological caveats.
} 
its use has also expanded towards organizational analysis (Capoccia and Keleman 2007), which involve shorter time spans. The analysis of ACO therefore situates between the short-term assessments coming from practitioners, and the longer-term perspectives of macro-historical analyses. This medium-term time span allows both the analysis of detailed political events, as well as the study of more structural paths.

In order to meet its objectives, the research resorts to official documents, academic works, and media content, as well as eight semi-structured in-depth interviews to ACO's high officials, and external policy experts. The study of changes over time, as well as the multi-dimensional framework used for unraveling causal processes, aim to provide a comprehensive picture of the different strategies and contextual factors undermining ACO's work, as well as the successful features that were able to persist over time. Moreover, by distinguishing between potentially reversible and non-reversible performance paths, the article offers a perspective that moves beyond performance alone and accounts for more general institutional capacity.

\section{The Argentine Anti-Corruption Office (ACO)}

\subsection{Brief description}

ACO is born against the backdrop of the anti-corruption platform with which the centrist coalition Alianza led by Fernando De la Rua wins the Argentine national elections in October 1999, ending the 10-year mandate of Peronistconservative Carlos Menem. It is conceived as a replacement for the previous Public Ethics Office, which had been inactive since its creation in 1997.

The agency is instituted by law in December 1999, and endowed with both preventive and investigative powers, following the single-agency model of Singapore and Hong Kong (Meagher 2005). These powers are in line with the demands of the Inter-American Convention Against Corruption (IACAC), and are meant to represent an important tool to fight national and transnational bribery, traffic of influences and illicit enrichment.

In spite of its political profile, a signal of independence is given to the public by constituting the agency as a special unit within the Ministry of Justice. In that sense, the President preserves appointment and removal powers regarding ACO's General Director ${ }^{2}$, after a recommendation is issued by the Minister of

\footnotetext{
${ }^{2}$ The General Director is called the General Prosecutor for Administrative Affairs, and has the hierarchical level of Secretary of State.
} 
Justice. ACO cannot decide upon its own budget, but it can receive external funding, both from national and international entities. In 2012 it employed around 100 people, and had a budget above USD 4 million $(0.001 \%$ of Argentina's GDP).

Its scope of action is limited to monitoring the organizations and public servants belonging to the national executive branch (the presidency, its ministries and all their functional units, both centralized and decentralized). Among its obligations is the enforcement of the Public Ethics Law 25188, which includes the design, implementation and follow-up of a system of annual assets declaration for public servants within the executive branch. It also receives reports from other public entities, private parties and auditing bodies on potential corruption crimes to be investigated and brought to justice. In its preventive dimension, ACO sets the guidelines for the national strategies concerning legislation, administrative reform, public awareness and civil servant's formation regarding anti-corruption measures.

ACO has a simple organizational chart, with two main Departments under the General Director: the Investigations Department, which receives, evaluates, investigates and follows up on corruption complaints, and the Transparency Policies Department, which decides upon the selection of significant cases, studies the causes of corruption and potential subsequent interventions, and is in charge of civil servants' assets declaration system. A small number of Investigations Coordinators (normally five) work under the Investigations Director and undertake ACO's investigations.

The agency is financed by three parties: the national budget, other local cooperating entities and international loans and subsidies that serve specific projects.

\subsection{Agency Performance}

During its almost 15 years of existence, the Argentine Anti-Corruption Office has lived through four different administrations ${ }^{3}$, survived the public spending cuts of the 2001 and 2002 economic turmoil, and adopted different intervention strategies and activity levels.

In one of the few works dedicated to quantifying and evaluating the outputs and outcomes of ACAs from a donors' perspective, one aspect that seems constant when assessing performance is the evolution in the number of annual

\footnotetext{
${ }^{3}$ Presidents Fernando De la Rua, UCR-Frepaso coalition (1999-2001); Eduardo Duhalde, PJ party (2002); Nestor Kirchner, FPV (a subsidiary of PJ) (2003-2007); Cristina Fernandez de Kirchner FPV).
} 
investigations initiated, and the status of each at the end of the year (Johnsøn, Hechler, De Sousa and Mathise 2011). Although these investigations represent only a fraction of ACAs' overall output -and therefore ignore longer term outcomes-, they serve as simple and illustrative measures to overview performance, which is our main dependent variable in this study.

Figure 1 presents a stacked column chart providing information on the total number of cases initiated by the agency in a given year, as well as the file status reached at the end of the same year. These figures are taken from the annual reports published by the agency itself. Each file is a new investigation opened after a formal complaint enters the agency, submitted by either another public entity, a private agent or an auditing body. Also, the agency can act ex officio, as well as based on salient cases brought on by the media. One general classification divides files into a) those that, based on substantial evidence of crime, are referred to the justice system, accompanied by all relevant elements; b) those that, constituting an administrative affair, are referred to the public organization in question; c) those for which further investigation is pending; and d) those cases that are either turned down as not applicable, or that are closed due to insufficient evidence or being deemed unimportant within the agency's scope and objectives ${ }^{4}$. In spite of the many efforts, by 2012 only one sentence had been issued by the Judiciary.

\footnotetext{
${ }^{4}$ The procedural flowchart of the agency can be visualized in any of the annual ACO Reports (e.g. ACO 2001).
} 
Figure 1: Argentine Anti-Corruption Office - Number and status of files initiated per year

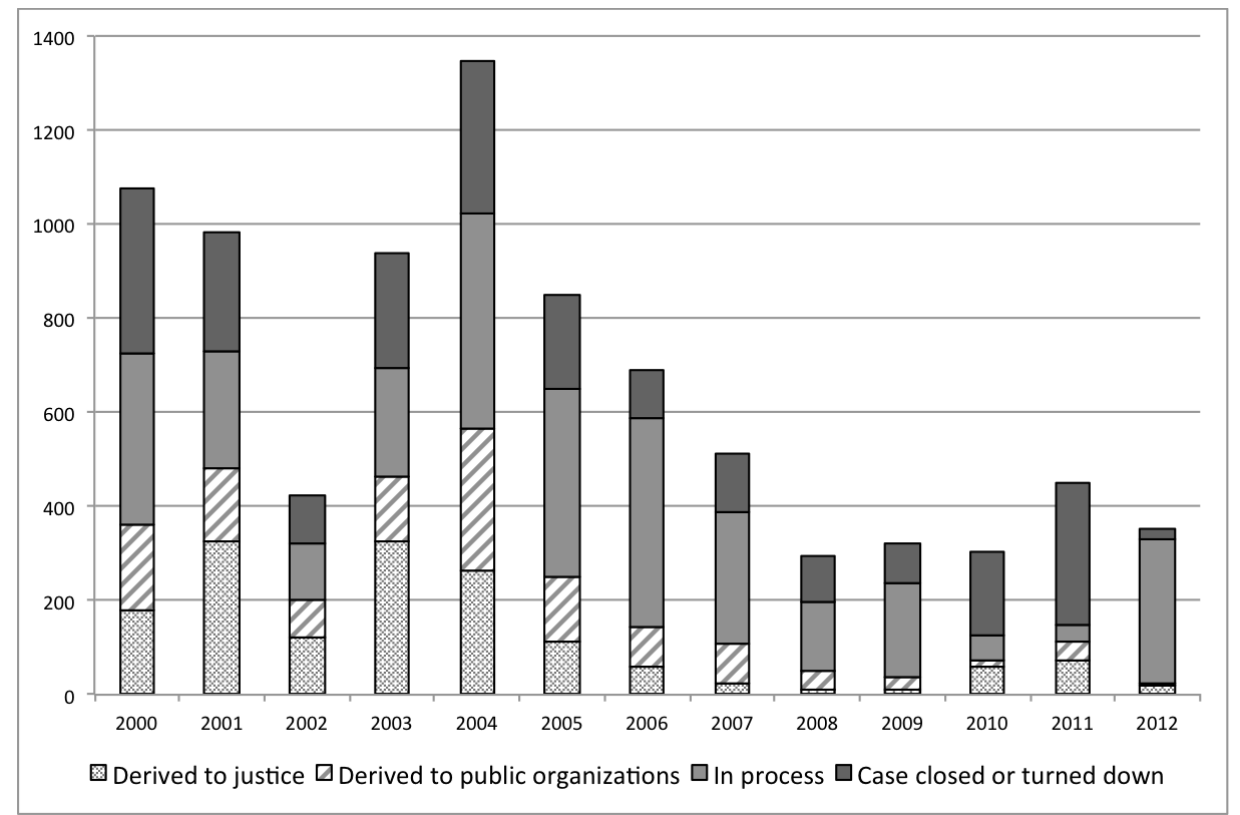

Source: Author's elaboration based on the Anti-Corruption Office Annual reports available at: www.anticorrupcion.gov.ar.

Several observations can be drawn from this simple chart. The first is the clear downwards trend in the total number of files initiated by the agency since 2004. These start at 1144 in ACO's first operational year, peak in 2004 with 1368 cases, and reach an average of 327 files between 2008-2012.

It can also be noted that the fraction of pending cases plus closed and turned down files (upper solid colors) becomes substantially higher than the number of 'resolved' cases within the agency over time (lower patterned colors). The comparison is particularly striking in the number of cases derived to justice, which fall from 325 in 2001 to 18 in 2012 (with a peak of 327 in 2003 and a trough of 9 in 2009).

These two facts suggest important changes in the operational activity of ACO, as its investigative powers in particular seem to have waned over the study period. The next section is dedicated to unravelling the trajectory of ACO from its genesis until 2012, highlighting the key junctures that explain at least part of the trend in performance sketched above, as well as the organizational and institutional foundations that may revamp ACO's activity in the future. 


\section{Inhibitors and Drivers: critical junctures}

The combination of structural conditions and contingencies set the organization on a particular institutional trajectory likely to endure, and that is difficult -although not impossible- to reverse. The next subsections assess the different phases of ACO's development, determined by a series of institutional and organizational dimensions. As previously mentioned in the analytical section, these are: a) the agency's legal mandate; b) its operational autonomy and resources; c) its political support; d) the dynamism of its leadership; e) the role of complementary institutions; f) the agency's links with donors; g) its overall performance.

\subsection{Initial momentum: political will, fertile context (2000- 2001)}

After ten years of center-right government and a long series of corruption scandals, the newcomer Alianza coalition delivers on one of its anti-corruption promises and sets up the Anti-Corruption Office within a few days of taking office in December 1999.

ACO's design is innovative and unprecedented in the Argentine context, as it combines investigation, prosecution and prevention powers, following the format of the Office of the Inspector General in the United States. Insights from the academic work of Donatella Della Porta and Alessandro Pizzorno around the mani pulite affair in Italy shape the creation of the agency (De Michele). $\mathrm{ACO}$ is meant to be kept small and dynamic, and "operate largely through incentives in a more informal way than the traditionally sluggish Argentine judiciary" (Massoni).

Similarly, its civil servants are recruited in virtually all cases through fast, informal, meritocratic contests, in order to avoid more lengthy procedures (Massoni). The resulting teams are judged highly professional and multidisciplinary (Massoni, Colombo), although their tenure is in general not secured, and the agency runs on temporary short-term contracts for about half of the staff (ACO Reports 2001 2002).

In 2001, ACO is financed in a proportion of about two thirds by the central government, with the remainder coming from cooperating entities and donors. This proportion changes substantially in subsequent years, and from 2003 onwards cooperating entities supply most of the budget ${ }^{5}$ (CIPCE 2012).

\footnotetext{
${ }^{5}$ For detailed budget figures over the period, see CIPCE 2012: 24-26.
} 
Political support for the new organization is high, in particular from the Justice Minister Ricardo Gil Lavedra, to whom the setup of the agency is delegated (Meagher 2005; Massoni). As Gil Lavedra is replaced by Jorge De la Rua (the President's brother) in October 2000, ACO continues to operate normally and retains political support, although the personal relationship between the agency's leader and the minister becomes notably more distant (Massoni). After the ministerial turnover, a conscious decision is made by ACO's management not to submit any resignation in order to highlight the agency's independent profile (Massoni). This decision sets an important precedent that increases ACO's de facto autonomy until around 2005. De facto autonomy is reinforced even further when the agency advances investigations involving high officials from the ruling administration (De Michele).

The role of complementary institutions is rather weak and highly dependent upon the personal affinity between the respective leaders. ACO absorbes only few financial and human resources from the Public Ethics Office (PEO), the Menem-initiated judicial agency that ACO is meant to replace (Massoni). Something similar happens with respect to other ministerial agencies. Relations with the General Auditor and the Executive Auditing Commission, on the other hand, are rather good during these years, if only due to the leaders' personal affinity (Massoni).

The judiciary is reticent to aid ACO in its investigative role. In Garrido's view "The judicial corporation aimed at delaying investigations until the next administration came to power". The Public Ethics Bill passed in September 1999 had foreseen that judges declare their assets before a legislative commission, but this is never implemented. Due to its lack of jurisdiction, ACO cannot enforce compliance within the judicial or the legislative branches. Still, $\mathrm{ACO}$ attempts to create some incentives by sending the innovative in-house developed software for civil servants' assets declaration both to the Supreme Court and the two legislative chambers, with no reception (De Michele, Massoni). Some lukewarm initiatives aim to extend the declaration system to union leaders as well, only to fail very quickly (LN 29-10-2002).

From around 2000 until 2003, the anti-corruption community is very developed, with a high number of active and well coordinated NGOs. ACO works closely with them, although in De Michele's perspective it tries to remain independent. On the external front, donor institutions are key players in ACO's initial institutional development. The World Bank donates crucial funds to the agency, which are used to finance the assets declaration software (De Michele). Also, a dynamic network is built during those years with other anti-corruption agencies, such as IADB's Office of Institutional Integrity and the UN's Office of Internal Oversight Services (OIOS) (Garrido, ACO Report 2001), as well 
as with the OECD (ACO Report 2001).

In Latin America, Argentina plays a strong role within the Organization of American States (OAS), as it takes the lead regarding the monitoring mechanisms of the Inter-American Convention Against Corruption (ACO Report 2001). The country also leads the Ethics Network of the Americas, along with Uruguay, Chile, Puerto Rico, Canada, the U.S., Brasil and Mexico, and fosters many bilateral exchanges, in particular in terms of cooperation with the U.S. In contrast, cooperation initiatives with other countries fail, such as Peru, Venezuela, Ecuador, Panama or Costa Rica (Raigorodsky). To a big extent, ACO's strong international position is the result of its high expertise and the good connections of the directors of the Transparency Policies department (Colombo). According to De Michele "finding external partners was critical in ACO's strategy to remain operationally autonomous".

In terms of performance, the agency initiates a high number of files given its size and budget. The asset declaration software for public servants developed with funds from the World Bank is the main milestone during these years. The previous system put in place by the Public Ethics Office was manual, badly organized and had little follow up (Massoni). Intellectual property rights for the new system remain with the Argentine state (De Michele), and the software put Argentina at the forefront in this field at an international level (Garrido). The system continues to be in place throughout the whole period of study.

All in all, these years are regarded as a big window of opportunity for ACO to be aggressive, and representatives of the anti-corruption community see them as the most dynamic (Dubinski).

\subsection{Resisting the crisis (2002-2003)}

In December 2001 the Alianza government is ousted from power by widespread street protests, amidst a wave of social discontent and deep economic recession. In January 2002 the interim Peronist government of Eduardo Duhalde takes office, lasting until May 2003.

The Duhalde administration is overall respectful of ACO's de facto autonomy (De Michele, Massoni), although the anti-corruption discourse is not perceived as a priority in Duhalde's agenda (Garrido). The agency remains as an isolated unit, given that its potential termination is deemed too politically costly at the time (Garrido). In spite of the crisis and government change, the budget is not greatly affected (CIPCE 2012). According to ACO's director, "it seemed that the new administration was concerned not to signal any influence over the 
agency" (Massoni), and ACO continued to work normally in terms of both prevention and investigations (Massoni, Garrido, Raigorodsky).

ACO's personnel continues to face difficulties in entering the permanent bureaucratic career. In Massoni's words: "the procedure to acquire tenure protection was exceedingly slow and burdensome". Some officials pass permanent career selection procedures but are never allowed to take these positions (Colombo). Salaries remain low due to cuts effected by the previous administration and a hiring freeze, which creates an uncertain horizon for the staff and endangers agency autonomy (Garrido, Colombo). In spite of all this, there is not much turnover in personnel during these years (Massoni).

As the work of ACO becomes more visible within the executive branch, complementary institutions increase their cooperation (ACO Report 2002). The tax authority (AFIP) provides now essential help in cross-validating data in the asset declarations gathered by ACO, and in instructing civil servants on how to fill these electronic declarations. The asset declarations system catches plenty of media attention (Massoni). This, in turn, has a strong impact in corruption prevention, as several officials resign after incompatibilities become clear (De Michele), and a number of federal judges follow amidst media scandals resulting from ACO's investigations (Garrido).

With Congress dialogue remains somewhat active (ACO Report 2002), although concrete progress is stalled. Key anti-corruption legislative drafts are blocked these years, such as the Free Information and Lobby Regulation initiatives (Massoni). With NGOs, however, there is an active interaction and multiple exchanges, in the context of the profound crisis the country was undergoing (ACO Report 2002 2003).

In terms of international cooperation, most links continue to be active, although the lack of financial resources affects the frequency of contacts (ACO Report 2002). Relationships within OAS continue, but these decrease with the U.N., and the U.S. American government (ACO Report 2002). The World Bank makes a third substantial donation in 2003 (ACO Report 2003), although these donations cease from then on. Argentina's collaboration with other Latin American countries slows down as well, and much of its international leverage in the anti-corruption fight is lost (Raigorodsky).

The total number of files initiated, as well as the investigations referred to the judiciary drop dramatically, although civil servants' compliance with the asset disclosure obligation remains close to 95\% (ACO Report 2002).

When ACO's first General Director, Jose Massoni, leaves the agency in December 2002, Duhalde's Justice Minister Juan Jose Alvarez replaces him with the Investigations Department Director, Manuel Garrido, who momentarily 
holds both positions. This decision translates into a smooth transition with a high degree of continuity, even after the change of government in May 2003, and the arrival of Nestor Kirchner to the Presidency.

\subsection{Revamped activity, less autonomy (2004)}

Towards the end of 2003, Kirchner's Justice Minister Gustavo Beliz appoints Daniel Morin as the new head of ACO. His leadership style is perceived to create some frictions with existing ACO staff (Garrido, Colombo). Yet, in Colombo's words: "Morin's agenda and intentions for the agency were overall positive".

When the Department of Investigations becomes acephalous in January 2004, one level of management is bypassed, as Morin interacts directly with the Investigations Coordinators within the Department, and chooses not to replace the departmental Director (Colombo).

The budget allocated to the agency by the central government is cut by $34 \%$ in 2004 (LN, 1-3-2004), in spite of which the number of investigations reaches its highest point throughout the period. This is mainly due to the big increase in complaints made by individuals (ACO Report 2004). However, none of the investigations referred to the judiciary had reached trial status by then.

The Justice Minister at the time makes attempts to improve the stability of the personnel (Montero), but many positions remain vacant, and previous contests are not resolved (Raigorodsky). Also, in Garrido's view, since the end of 2003 new recruits have less formation on anti-corruption issues.

The asset declaration system continues to grow and develop, as additional cross-validation platforms are incorporated. For example, it becomes then possible to integrate data from the automobile and vessels registries in order to check inconsistencies. Also, ACO develops a system of automatic red flags for declarations, improving overall efficiency (Raigorodsky, ACO Report 2004). Other software initiatives were, however, blocked. ACO foresees buying a powerful software for big data browsing, but the acquisition is cancelled due to budget constraints (Colombo).

One important achievement during these years is that ACO begins to be accepted as part of the prosecution by the judiciary, which was met with strong resistance earlier on. Also, the agency encourages courts to endorse a more comprehensive interpretation of incompatible activities in the public office (Colombo).

A profound disconnect exists between ACO and the national Prosecutor's 
Office of Administrative Investigations (POAI), the organization that investigates corruption externally, due to the lack of affinity between their respective leaders (Garrido, Colombo). The relationship with Congress remains weak in investigative matters, and there are only some interactions regarding transparency policies (Colombo).

As the Kirchner administration distances itself from the U.S., and Argentina becomes an upper middle income country, international cooperation withdraws from the country. This occurs at a general level, but is well reflected in the anti-corruption area in particular (Raigorodsky). ACO still receives some help from the IADB in order to compile methodologies to cross-validate data with different national assets databases, and cooperation continues with OAS, and to a lesser extent with the U.N. (ACO Report 2004). The World Bank ceases to be financially present at this point (CIPCE 2012).

After Beliz resigns as Justice minister in July 2004, Horacio Rosatti takes his place. Morin, who had been appointed by Beliz, resigns as Director of ACO in December 2004.

\subsection{Focus shift: lower investigative profile, more 'educational' policies (2005-2007)}

In January 2005 Abel Fleitas Ortiz de Rozas becomes the new Director of ACO. As he takes office, he promotes the strengthening of prevention initiatives, in particular in the area of access to information (LN 17-12-2004). In general, it is perceived that ACO's work shifts towards educational and preventive issues during these years (Mesicic Report 2011: 45), with the leadership undertaking a low-impact, less combative strategy (Garrido, Colombo).

An internal re-organization of the agency takes place. It seeks to concentrate operational efforts only on the investigations that have high chances to reach trial status, leading to a high number of cases closed (ACO Report 2005).

In a context of increasing inflation, ACO's budget is cut in nominal terms by $6 \%$ (LN 6-10-2004), and the overall number of investigations pursued falls significantly in relation to the previous year. The continuity of certain pilot projects is compromised, as in the case of the Plan Provincias programme ${ }^{6}$, which loses support during these years (Raigorodsky).

\footnotetext{
${ }^{6}$ The Plan Provincias programme sought to encourage sub-national governments to engage in anti-corruption initiatives, even though ACO had no jurisdiction over these.
} 
After a long acephaly of the Investigations Department, a new Director is appointed, Martin Montero. In Montero's view, this acephaly had not affected the department's work significantly, but there were clear infrastructural limitations. The department counted on approximately 35 people for a total of 700 ongoing files, along with around 70 prosecutions. According to Montero, there were not enough human or technical resources due to a lack of political will: "Half of the computers were obsolete. I spent two years asking for 10 new computers with printers which never arrived" (Montero).

With the arrival of Fleitas an important procedural and legal change takes place, affecting the operational dynamics of ACO. Earlier, Investigations Coordinators had autonomous powers to request judicial investigative measures in the cases where ACO was an interested party. From then on, a new front desk starts to decide which cases enter ACO. Investigations Coordinators cannot initiate files ex officio anymore, which affects their motivation levels (Colombo). According to Colombo, "This seemed like a trivial organizational issue, but was completely crucial".

The perception during these years is that the coordination with regulatory agencies and auditing bodies remains generally low (Montero, Garrido). The relationship with the General Auditor and the Executive Auditing Commission improves slightly (Montero), although the number of reports coming from these two auditing bodies becomes marginal after having peaked in 2004-2006 (CIPCE 2012).

ACO maintains cordial relationships with POAI. Some obstacles emerge when ACO refuses to share civil servants' assets declarations to POAI for further investigation (Garrido). Also, substantial problems occur with the tax authority AFIP. In mid-2006, ACO requests AFIP sensitive patrimonial information of government officials, including one top servant from AFIP itself. The tax authority refuses to provide this information, and further resorts to a legal manoeuvre resulting in AFIP ceasing to share all fiscal databases in the future (LN 24-11-2006; Montero). This represents a major setback for the agency, as its legal implications are substantial: many ongoing investigations could be potentially stalled, without the possibility of neither closing nor advancing them (Montero). This situation continues throughout the entire period of study.

On the legislative front, ACO produces important legislative drafts in this period that are handed to the Justice Ministry without much reception, as in the case of the re-edited Lobby Regulation initiative (Raigorodsky).

In $2005 \mathrm{ACO}$ receives cooperation from UNDP and the British Government, in the format of financial assistance to develop prevention policies (ACO Report 
2005). Between 2006 and 2010 UNDP grants loans representing between $9 \%$ (2006) and less than 1\% (2010) of ACO's total budget (CIPCE 2012).

During this phase, ACO is perceived to lose overall autonomy (Garrido). In Colombo's words: "Although tensions with the ruling coalition had always been present, the situation worsens notably". The case is similar for other autonomous and semi-autonomous agencies in the country, which lose power to different political 'clientele', effectively hindering horizontal coordination between the agencies (Mazzei).

\subsection{Opacity and inactivity (2008-2012)}

In January 2008 the recently elected government of Cristina Fernandez de Kirchner appoints Anibal Fernandez as the new Justice Minister. In February, the minister initiates a reform of ACO's internal procedures that further limits the work of the Investigations Coordinators. The changes prohibit the Investigations Coordinators and the Investigations Director from signing information requests. After the reform this power remains exclusively with the General Director.

The change greatly affects the operational capacity of the agency. According to Montero: "Until then no Minister had directly messed with ACO. This was the first time, and it was brutal". Later on, Fernandez issues another resolution modifying other aspects of ACO's work, including handing the complete coordination of investigations to the General Director, which renders the Investigations Department superfluous. What follows, is that many Investigations Coordinators leave the agency in the search for better positions (Montero).

The changes introduced mean in practice that the full workload was on the General Director, Fleitas (Montero). To make things worse, Fleitas suffers at the time from a terminal illness that leads to his death in early December 2008. In late January 2009 the new General Director, Julio Vitobello takes office. According to Montero, this transition was chaotic, due to the almost complete concentration of tasks in Fleitas' hands: "In this sense, his death was traumatic also at an organizational level. The transition was very messy, nobody was in charge, all activity was completely paralized." (Montero). From OAS's follow-up report on the Inter-American Convention Against Corruption policies, it emerges that these years there is a low number of people (14) pursuing investigations. The report recommends to increase ACO's personnel (Mesicic Report 2013).

Other aspects influence the operational capacity of the agency as well. While 
the budget coming from cooperating entities grows steadily over the period (following inflation), the national budget is subject to swings. In 2009, for example, these funds fall by more than a half in nominal terms. Additionally, contests to acquire tenure protection for ACO's personnel are further undermined. If until then the resolution of contests was delayed through different mechanisms, these are now fully interrupted (Montero). Finally, in terms of its organizational chart, the Fleitas administration had created the positions of Investigations Sub-Directors, but these positions remain vacant for many years and are filled only towards the end of the study period.

The coordination between ACO and the prosecutors from the Executive Auditing Commission and POAI occurs on the basis of personal relationships only, but there are no established mechanisms for this purpose (Mesicic report 2013: 46-47). Exchanges with AFIP remain scarce, after data exchanges come to an end. ACO loses most of the previous media attention it had captured: "ACO turns to complete opacity" (Garrido).

External cooperation is almost inexistent during these years. By 2010 the only external source of funding comes from UNDP and the British Government, but now represents a mere $0.007 \%$ of the agency's budget (ACO Report 2008, CIPCE 2012).

The number of investigations reaches its lowest point during these years. Moreover, the investigations that had reached the Federal Courts by 2012 were the ones initiated between 2000 and 2003 (Colombo). On occasions, the continuity of investigations can only be attributed to the fact that the same person in charge continued to work for ACO (Massoni).

Yet, some important milestones cannot be reversed, as is the case of the assets declarations. The compliance reaches almost 100\% (CIPCE 2012), and the system is seen as the most important achievement in the anti-corruption fight (De Michele, Massoni, Colombo, Raigorodsky, Mesecic report 2013) ${ }^{7}$.

\subsection{Findings}

The previous sections reveal a rather heterogeneous development in ACO's work and achievements. On the basis of the critical junctures and dimensions

\footnotetext{
${ }^{7}$ In May 2013 a bill is passed by which the asset declaration system changes substantially (Law 26.857). On one hand, the law obliges all declarations to be searchable online, which facilitates access (before a special request had to be made each time). On the other, it changes the format of the declaration, such that a great number of details are lost. Public servants do not need to account for their relatives' assets or explain the source of their wealth anymore. The initiative is harshly criticized by NGOs (LN 23-05-2013).
} 
analyzed, the findings suggest the following set of paths:

\begin{tabular}{lccccc}
\hline \hline Analytical dimensions & $2000-1$ & $2002-3$ & 2004 & $2005-7$ & $2008-2012$ \\
\hline Legal mandate & +- & +- & - & - & - \\
Operational autonomy \& resources & + & - & +- & - & - \\
Political support & + & +- & +- & - & - \\
Leadership & + & + & + & - & - \\
Compl. institutions & - & +- & +- & - & - \\
Links with donors \& NGOs & + & + & - & + & - \\
\hline Performance & + & - & + & - & - \\
\hline
\end{tabular}

The overall picture suggests a steady decline in performance throughout the period, that can be attributed to a greater or lesser extent to all dimensions pointed by the literature as important, but where the role of operational autonomy, political support and leadership are perhaps the most determinant ones. The case invites some general reflections that have implications both for the future of ACO, as well as the future of ACAs more generally.

ACO was set up in the midst of an active anti-corruption rhetoric and it gathered strong initial momentum. The agency was a high priority for the Justice Ministry at the time, and was initially endowed with high operational autonomy and highly qualified personnel. However, it was never given full independence from politics. ACO was designed to become a trademark of the newly arrived administration, with a primary focus on the previous administration's rampant corruption cases. In that sense, although the agency lacked independence, it was much more than the mere discourse-controlling instrument some scholars see in ACAs (Smilov 2009).

The lack of full legal autonomy, along with the intention of keeping ACO small and flexible paid off well at the beginning by granting it dynamism and visibility. Ultimately, however, these features shaped ACO as a parallel bureaucracy, which made it highly dependent upon circumstantial political support. This affected the endurance of its initial nature and objectives. As ACO's first General Director put it "Ultimately, ACO's informality [in its early days] meant that all critical advancements depended purely on its offcials' will and good spirit" (Massoni). In later years the agency remained as an isolated, self-contained organization.

Similarly, ACO could not achieve a high level of embeddedness within the broader governance matrix. The work with complementary institutions was erratic and highly dependent upon leaders' affinity, more so than upon institutionalized relations. This aspect hindered its autonomy and performance further. 
Although the agency was not given high independence, it still turned out difficult for the ruling coalition to intervene in its operations. In consonance with the literature, the Argentine case suggests that ACO's termination was judged to be politically costly, as did very obvious interference in its operations (e. g. De Sousa 2010). For this reason, a series of subtle legal mechanisms were put in place to undermine its capacity and autonomy.

Several of the experts interviewed agree that ACO suffers from a design error by which its legal mandate depends upon the same jurisdiction that it should control, and can therefore be easily captured (Colombo, Montero, Dubinski). In fact, although legal autonomy is not necessarily determinant in performance, as many authors anticipated (e.g. Batory 2012), its lack makes the agency highly dependent upon leadership and political support. More importantly, legal autonomy affects the degree to which undermining strategies can be reversed.

Many aspects, on the other hand, speak of the potential of ACO. Certain achievements could not be reversed, such as the assets declaration system and the stronger recognition the agency enjoys when taking prosecution roles. Also, most of the mechanisms used to hinder the powers of the agency are based on low hierarchy laws that could be easily reversed. The low amount of sentences reached (only 1 sentence in all 14 years) owes more to the malfunctioning of the judiciary than to the lack of expertise within ACO (this is exhaustively explained in ACO Report 2004). Suspects resort to innumerable formal technicalities and dilatory defensive strategies to circumvent accusations (Mesicic Report 2013: 47).

In addition, the agency was always endowed with highly formed human resources. The times in which ACO was intervened, these human resources did not necessarily leave the organization, nor did the accumulated expertise. In terms of probity, although ACO was suspected of being used for internal political games, in reality it never suffered incidents of information leakage or experienced judicial complaints against any of its officials (Montero).

Finally, although donors withdrew from much of Argentine politics, the reestablishment of exchanges and the re-activation of the anti-corruption agenda is not unthinkable, given ACO's reputation and the overall high expertise of its personnel. It is perhaps an interesting lesson that, if the withdrawal of donors happens against a backdrop of increased economic prosperity, institutional setbacks may go unnoticed. 


\section{Concluding thoughts}

The present article has reviewed the many dimensions that play an important role in determining the performance and overall capacity of anti-corruption agencies in the context of challenging governance settings. It has made two important contributions to the literature, first by helping bridge a substantial gap on Latin American ACAs, and second, by showing the dynamics of an exemplifying case that displays a high degree of variance on several key aspects throughout its organizational life.

In Argentina, the Anti-corruption Office emerged as a well-functioning institutional response to the events taking place in the country during the late 1990s. But just as many other newly formed organizations in Argentina, its initial endowments were not sufficient to offset later changes in the political context. The lack of a fully autonomous legal mandate was partially compensated with effort-driven initiatives to increase de facto autonomy through high expertise, well-developed international networks and novel technological tools. The case illustrates, however, that these types of efforts can be gradually and subtly eroded through political intervention in governance settings that are prone to unpredictability. At the same time, some initial success enabled a degree of organizational capacity that is not so easily reversible, but can only be momentarily neutralized.

The findings help confirm the importance that previous works on ACAs have given to aspects such as the agency's legal and de facto autonomy, local political support, the role of complementary institutions, the cooperation with external partners and donors, and the quality of the agency's leadership. The analysis finds the first three (autonomy, political support and complementary institutions) to be particularly essential for the Argentine case. Potential policy initiatives should be geared towards increasing legal and operational autonomy, while critically improving the coordination of ACAs with other relevant players in the anti-corruption field. Higher autonomy is critical in order to minimize the intertemporal swings in performance often intended by selfinterested ruling coalitions. The maximization of performance itself, on the other hand, relies on a virtuous coordination between the agency and other players in the judiciary more generally.

Although idiosyncratic and contextual factors are essential to understanding ACAs, the study case also prompts a series of more universal methodological lessons.

First, that in-depth research of multi-dimensional aspects, including organizational, political and institutional dimensions can greatly illuminate the com- 
plexity of historical processes. While isolating single dimensions can help resolve predictions from competing theories, the case shows that governance processes involve in reality a multiplicity of intertwined factors. Considering these comprehensively can help avoid disappointment with results, or derive too fast policy interventions. Regarding single variables, however, a lot more should be done on the quantitative side to narrowly define, measure and estimate the impacts of different factors on anti-corruption performance.

Similarly, the work has also highlighted the contribution of taking a within-case time perspective, by which agencies' performance is judged against themselves in time instead of against another country's reality. Although cross-country analyses have been preferred by international donors due to their capacity to offer benchmarking patterns, in-depth analyses of the critical junctures faced by single polities might capture strikingly different and equally interesting angles.

Finally, the case has stressed the importance of looking beyond immediate performance and assessing more structural aspects informative of ACAs' future potential in the face of changing circumstances. Estimating how reversible certain paths are, is in general a richer approach to the subject of institutional development, as it allows to judge institutional capacity more generally than outcome-based performance only. It also enables better optimization strategies whenever interventions are needed. Longer-term perspectives are of course needed to successfully monitor how the interaction between structural and contextual processes develops.

In sum, although ACAs have not yet fared as initially expected, the high political cost of their termination can only lead to subtle manoeuvres that can potentially be reversed whenever the political winds change, or new windows of opportunity emerge. This is particularly true for those agencies that gathered high momentum in their initial phases. These anti-corruption warriors are still able to gather crucial expertise over the years and can help solve coordination problems in the fight for transparency. This occurs regardless of their incidental need to remain inactive in order to preserve survival at particular times. 


\section{Sources and Websites}

\section{Official Sources:}

- Anti-corruption Office Annual Reports - Argentina: www.anticorrupcion.gov.ar

- OAS Follow up of the Inter-American Convention Against Corruption: www.oas.org

- CIPCE Centro de Investigación y Prevención de la Criminalidad Económica

\section{Media articles:}

- LN - La Nacion Journal 29-10-2002 "El patrimonio de los sindicalistas"

- LN - La Nacion Journal 01-03-2004 "Disminuyó el gasto social y subió el burocrático"

- LN - La Nacion Journal 06-10-2004 "Prevén reducir los fondos para la OA"

- LN - La Nacion Journal 17-12-2004 "Fleitas Ortiz de Rozas, en la Oficina Anticorrupción"

- LN - La Nacion Journal 24-11-2006 "Corrupción: percibir y comprobar"

- LN - La Nacion Journal 23-05-2013 "Denuncian que los funcionarios ahora podrán ocultar su patrimonio"

\section{List of interviews:}

- José Massoni, General Director of the Anti-Corruption Office, Dec 1999 - Dec 2002.

- Roberto de Michele, Transparency Policies Department Director Dec 1999 - Oct 2002.

- Manuel Garrido, General Director of the Anti-Corruption Office, Dec 2002 - and Investigations Department Director, Dec 1999 - Oct 2003.

- Nicolás Raigorodsky, Transparency Policies Department Director, Nov 2002 - Feb 2008.

- Marcelo Colombo, Investigations Coordinator of the Investigations Department, Dec 1999 - Jun 2006. 
- Martin Montero, Investigations Department Director, Jun 2005 - Jan 2009.

- Hector Mazzei, Member of the Argentine Governmental Agents Corps (AGs), expert in autonomous agencies.

- Alejandro Dubinski, former member of the NGO network "Foro Social para la Transparencia".

\section{Interviewees' Selection Strategy}

The selection strategy of interviewees consisted in mapping all hierarchical positions of ACO, which showed four main roles: ACO's General Director; ACO's Transparency Director; ACO's Investigations Director and ACO's Investigations' coordinators. All of the public servants covering these positions for which a contact email or phone was found were contacted for a short interview. The response rate was high, except for public servants that were still in these positions at the moment of the interviews (May and December 2012). Additional public administration experts and anticorruption NGOs stakeholders were contacted, based on their appearances in the two main Argentine journals, Clarin and La Nacion, in articles where the key search term "Agencia Anticorrupcion" was found between 1999 and 2012. 


\section{References}

ACO (2001). Oficina Anticorrupción. Informe de Gestión 2001. Technical report, Argentine Anti-corruption Office. Accessible: http://www.anticorrupcion.gov.ar/INFORME_20ANUAL_202001.pdf.

ACO (2002). Oficina Anticorrupción. Informe de Gestión 2002. Technical report, Argentine Anti-corruption Office. Accessible: http://www.anticorrupcion.gov.ar/EJECUTIVO_20DEFINITIVO.pdf.

ACO (2003). Oficina Anticorrupción. Informe de Gestión 2003. Technical report, Argentine Anti-corruption Office. Accessible: http://www.anticorrupcion.gov.ar/INFORME_20ANUAL_202003.PDF.

ACO (2004). Oficina Anticorrupción. Informe de Gestión 2004. Technical report, Argentine Anti-corruption Office. Accessible: http://www.anticorrupcion.gov.ar/documentos/informe_20anual_202004.PDF.

ACO (2005). Oficina Anticorrupción. Informe de Gestión 2005. Technical report, Argentine Anti-corruption Office. Accessible: http://www.anticorrupcion.gov.ar/documentos/Informe_20Anual_202005.pdf.

ACO (2008). Oficina Anticorrupción. Informe de Gestión 2008. Technical report, Argentine Anti-corruption Office. Accessible: http://www.anticorrupcion.gov.ar/documentos/Informe_20Anual_2008OA_20def.pdf.

Bennett, A. (2008). Process tracing: A bayesian perspective. In BoxSteffensmeier, J. M., Brady, H. E., and Collier, D., editors, The Oxford Handbook of Political Methdology. Oxford University Press.

Capoccia, G. and Kelemen, R. D. (2007). The study of critical junctures: Theory, narrative, and counterfactuals in historical institutionalism. World Politics, 59(03):341-369.

Charron, N. (2008). Mapping and measuring the impact of anti-corruption agencies: a new dataset for 18 countries. Prepared for the New Public Management and the Quality of Government conference.

CIPCE (2012). La oficina anticorrupción: análisis de su desempeño a 12 años de su creación. Technical report, Centro de Investigación y Prevención de la Criminalidad Económica.

Collier, R. B. and Collier, D. (1991). Shaping the political arena. Princeton University Press Princeton. 
De Sousa, L. (2010). Anti-corruption agencies: between empowerment and irrelevance. Crime, law and social change, 53(1):5-22.

De Speville, B. (2010). Anticorruption commissions: the Hong Kong model revisited. Asia-Pacific Review, 17(1):47-71.

Dionisie, D. and Checchi, F. (2008). Corruption and Anti-Corruption Agencies in Eastern Europe and the CIS: a Practitioners Experience. Bratislava: United Nations Development Programme.

Doig, A. (1995). Good government and sustainable anti-corruption strategies: A role for independent anti-corruption agencies? Public Administration and Development, 15(2):151-165.

Doig, A. (2012). Conclusion to the special issue: Time to consider prevention as well as retribution? Public Administration and Development, 32(1):129135 .

Doig, A., Watt, D., and Williams, R. (2005). Measuring success in five african anti-corruption commissions-the cases of ghana, malawi, tanzania, uganda \& zambia. U4 Issue, 12(9).

Doig, A., Watt, D., and Williams, R. (2006). Hands-on or hands-off? anticorruption agencies in action, donor expectations, and a good enough reality. Public Administration and Development, 26(2):163-172.

Doig, A., Watt, D., and Williams, R. (2007). Why do developing country anti-corruption commissions fail to deal with corruption? understanding the three dilemmas of organisational development, performance expectation, and donor and government cycles. Public Administration and Development, $27(3): 251-259$.

Head, B. W. (2012). The contribution of integrity agencies to good governance. Policy Studies, 33(1):7-20.

Hussmann, K., Hechler, H., and Peñailillo, M. (2009). Institutional arrangements for corruption prevention: Considerations for the implementation of the united nations convention against corruption article 6. U4 Issue, 2009(4).

Johnsøn, J., Hechler, H., De Sousa, L., and Mathisen, H. (2011). How to monitor and evaluate anti-corruption agencies: Guidelines for agencies, donors, and evaluators. U4 Issue, 2011(8).

Langseth, P. (2001). Anti-corruption agencies. In Experts Meeting, National Integrity Steering Committee (NISC), Jan, volume 22. 
Meagher, P. (2004). Anti-corruption agencies: A review of experience. The IRIS Discussion Papers on Institutions and Development.

Meagher, P. (2005). Anti-corruption agencies: Rhetoric versus reality. The Journal of Policy Reform, 8(1):69-103.

MESICIC (2013). Argentina: final report - fourth round. Technical report, Organization of American States. Mechanism for Follow-up on the Implementation of the Inter-American Convention Aganist Corruption. Accessible: http://www.oas.org/juridico/PDFs/mesicic4_arg_sp.pdf.

Page, S. E. et al. (2006). Path dependence. Quarterly Journal of Political Science, 1(1):87-115.

Peters, B. G., Pierre, J., and King, D. S. (2005). The politics of path dependency: Political conflict in historical institutionalism. Journal of Politics, 67(4):1275-1300.

Pierson, P. (2000). Increasing returns, path dependence, and the study of politics. American Political Science Review, 94(2):251-267.

Pope, J. and Vogl, F. (2000). Making anticorruption agencies more effective. Finance and Development, 37(2):6-9.

Quah, J. S. (2008). Anti-corruption agencies in four asian countries: A comparative analysis. In Bowornwathana, B. and Wescott, C., editors, Comparative governance reform in Asia: Democracy, corruption, and government trust. Emerald Group Publishing.

Shah, A. (2007). Performance accountability and combating corruption. World Bank Publications.

Smilov, D. (2010). Anticorruption agencies: expressive, constructivist and strategic uses. Crime, law and social change, 53(1):67-77.

Streeck, W. and Thelen, K. A. (2005). Beyond continuity: institutional change in advanced political economies. Oxford University Press.

Thelen, K. (1999). Historical institutionalism in comparative politics. Annual review of political science, 2(1):369-404.

UNDP (2005). Institutional arrangements to combat corruption, a comparative study. Technical report, United Nations Development Programme. Accessible: www.snap-undp.org.

UNDP (2011). Practitioners' guide to capacity assessment of anti-corruption agencies. Technical report, United Nations Development Programme. Accessible: www.undp.org. 


\section{Value creation of the research}

\section{Relevance}

The findings of the present dissertation entitled "Bureaucracies for Development, Oxymoron or Reality? Studies on State Capacity in Challenging Governance Contexts" have a series of implications for the institutional maturity and wellbeing of societies, in particular in developing countries.

A first finding suggests that civil services which preserve higher operational autonomy from short-term political pressure can achieve more in the implementation of health policies such as the reduction of child mortality and tuberculosis.

Considering that these health outcomes represent highly desirable social goals, the current research makes a valuable contribution towards better illuminating the governance determinants behind them. The governance aspects of health are normally less researched than more traditional economic and infrastructural factors.

Another phenomenon that was observed through the research is that the manipulation of professional civil services appears to be a chronic problem in the context of Latin American countries, in particular Argentina and Brazil. This emerges from the comprehensive examination of changes in portfolio structures and agencies in the two countries, where Argentina shows the greatest volatility. The findings ratify that institutions that set limits on power concentration help mitigate the problem.

Unravelling the particular rules and arrangements that help create a more stable and cooperative decision-making arena is an important goal. The detection of these institutions should be taken into consideration when planning comprehensive reforms in countries with a similar profile as the ones selected, and most likely before placing too much hope in policies alone.

Another of the findings concerns countries' organizational capacity in the anticorruption fight. From the in-depth examination of the Argentine Anti-Corruption 
Office, one can see that although the success of transparency initiatives depends greatly on political windows of opportunity and the original powers granted to the relevant stakeholders, the accumulation of expertise and capacity can still occur when the initial momentum is lost. It seems to be important to distinguish the factors that negatively affect organizational capacity in a structural way, from those that could be potentially easy to reverse. The Anti-corruption Office of Argentina suffered many subtle attacks, but still an important degree of capacity was built throughout the years. This finding offers an optimistic note regarding the role of anti-corruption agencies more generally, in a context where their effectiveness has been much debated.

In sum, the dissertation hopes to have made several social contributions towards a better understanding of state capacity building at different levels, and the role played by policymakers and civil servants in the context of challenging governance settings.

\section{Target Groups}

Apart from the wider academic community, the current research has informational value and entails policy implications for several other groups and organizations.

First, for national governments wanting to introduce public sector reforms or seeking to find devices to signal longer-term commitments. These may have direct economic implications, for example for international investors.

Second, for the international donor community in their efforts to seek adequate strategies for governance reforms in clientelistic or neopatrimonial polities. The findings can particularly be informative for the areas of health and anti-corruption.

Also, different NGOs and activists in the search of so called 'good governance' reforms, can see their debates enriched by some of the conclusions outlined in the present book.

Finally, policy practitioners, consultants, or experts in MDGs and anti-corruption can make use of this research to inform their decisions in the field. 


\section{Activities / Products}

In addition to the academic publications, conference presentations and media content that stemmed from this work, the following items were produced along the way:

- The development of a comprehensive database on state capacity and other relevant governance dimensions in more than 100 countries throughout a 20 year period.

- The development of an originally-compiled database on state structures, civil servants, career paths and agencification trends in Argentina and Brazil over a 20 -year period.

- The creation of novel objective indicators on both bureaucratic autonomy (BAIndex) and Organizational Chart Volatility of central public administrations (OCV).

\section{Innovation}

The products mentioned above are innovative in the field of state capacity studies and comparative public administration. The indices are original and represent new efforts to capture objective aspects of governance that can be used for comparisons across time and space. The database on state structures is highly innovative in the Latin American context, although similar efforts exist already for Ireland and Norway, and very recently parallel projects are in progress for a series of European countries: Belgium, France, the UK, Germany and the Netherlands.

\section{Schedule and Implementation}

A plan is foreseen for next three years to continue profiting from the efforts made in this dissertation, and to further develop many of the theoretical and practical ideas first outlined here. 


\section{Abstract in Dutch}

\section{Samenvatting}

Dit proefschrift onderzoekt de verschillende manieren waarop de kenmerken van de civiele diensten over de hele wereld effect hebben op welvaartsbevorderend beleid en het bouwen van de capaciteit van de nationale staat. In dit streven richt het zich op de interactie tussen een gekozen regerende coalitie en een permanente bureaucratie die probeert een zekere mate van autonomie te behouden. Gedurende de hoofdstukken, levert het diverse bijdragen via meerdere methodieken. Het eerste hoofdstuk geeft een overzicht van de literatuur over de capaciteit van de staat, beginnend bij de vroege studies van de jaren 1960. Het toont hoe het concept van staatscapaciteit is gedefinieerd en gemeten, en het brede regelen van bestaande interpretaties, afhankelijk van het disciplinaire gebied waarin het is ingebed. Hoofdstuk 2 onderzoekt de theoretische verschillen tussen staatscapaciteit en bureaucratische autonomie, en bepaalt de desbetreffende effecten op twee Millenium Development Goals, kindersterfte en tuberculose-niveaus. Gezien het gebrek aan goede alternatieven voor het meten van bureaucratische autonomie in de literatuur, biedt het een nieuwe index van bureaucratische autonomie, met drie bijzondere voordelen: het is objectief in plaats van op onderzoek gebaseerd, het is voldoende voor tijdreeksanalyses en bestrijkt een breed scala van landen. De bevindingen tonen aan dat een hogere autonomie zich vertaalt in snellere verbeteringen bij beide gezondheidsuitkomsten. Hoofdstuk 3 maakt gebruik van een oorspronkelijk samengestelde databank over bureaucratische functies in Argentini en Brazili, om uitgebreide en historische patronen vast te leggen in de relatie tussen de politiek en de bureaucratie. De resultaten tonen aan dat deze interactie twee belangrijke aspecten van de staatscapaciteit bepaalt: beleidsaanpassingsvermogen en beleidsvoorspelbaarheid, waarbij de laatste meer ontwikkeld in Brazili dan in Argentini. Het hoofdstuk verkent ook verschillende politieke economie elementen die achter het contrast zitten in de patronen die gevonden kunnen worden tussen de twee landen. Terwijl de vorige twee hoofdstukken voorstander zijn van een kwantitatieve en econometrische benadering voor de staatscapaciteit en civiele diensten, richt Hoofdstuk 4 zich op een kwalitatieve 
case-analyse om de evolutie in de prestaties van het Argentijnse Anti-corruptie Bureau van Argentini in de afgelopen jaren te laten zien. Het hoofdstuk maakt gebruik van diepte-interviews, media-inhoud en de officile verslagen om de politieke en institutionele determinanten te analyseren achter de grote variatie in de prestaties van het agentschap. In de conclusies, brengt het een aantal ideen naar voren over de mechanismen waarmee bureaucratische autonomie zowel wordt gebouwd als verarmd in de context van de opkomende economien, en het belang van het onderscheid tussen eenvoudig omkeerbare en niet-omkeerbare politieke strategien die de autonomie van het ambtenarenapparaat. Al met al, het proefschrift biedt nieuwe mogelijkheden voor de behandeling van het beleid en de instellingen in uitdagende bestuur-contexten, vanuit een grotendeels multidisciplinair perspectief dat elementen van de ontwikkeling van de economie, politieke economie, vergelijkende bestuurskunde en beleidsanalyse studies combineert. 


\section{Short Biography}

Luciana first obtained a political science degree from Buenos Aires University, and later completed an honorary MPhil in public policies at San Andres University, funded by the Argentine National Research Council (CONICET). Before joining the Maastricht Graduate School of Governance, she has worked for the Strategic Planning Office of the Buenos Aires government, the United Nations Development Programme (UNDP), and two public affairs agencies in London. As a UNU-MERIT fellow, Luciana has taken part in the project on Institutions and Long-Term growth funded by the French Development Agency (AFD). She is also a member of the Ronald Coase Institute in Washington, the European Political Science Association and the European Council of Political Research. 


\section{MGSoG Dissertation Series}

Carlos Cadena Gaitán

Green Politics in Latin American Cities - Sustainable Transport Agendas

MGSoG Dissertation Series, nr 43 (2014)

Katie Kuschminder

Female Return Migration and Reintegration Strategies in Ethiopia

MGSoG Dissertation Series, nr 42 (2014)

Metka Hercog

Highly-Skilled Migration and New Destination Countries

MGSoG Dissertation Series, nr 41 (2014)

Margaret Agaba Rugadya

Can Remittances Influence the Tenure and Quality of Housing in Uganda?

MGSoG Dissertation Series, nr 40 (2014)

Ilire Agimi

New Governance Under Limited Statehood

The Case of Local Government Reform in Kosovo

MGSoG Dissertation Series, nr 39 (2014)

Kristine Farla

Empirical Studies on Institutions, Policies and Economic Development

MGSoG Dissertation Series, nr 38 (2013)

Marina Petrovic

Social Assistance and Activation in the Pursuit of Happiness:

Shedding New Light on Old Policy Solutions to Social Exclusion

MGSoG Dissertation Series, nr 37 (2013)

Laura Torvinen

Assessing Governance Assessments; The Case of Mozambique

Governance Assessments in the Context of Aid Effectiveness Discourse

MGSoG Dissertation Series, nr 36 (2013)

Biniam Egu Bedasso

Institutional Change in the Long Shadow of Elites

Essays on Institutions, Human Capital and Ethnicity in Developing Countries

MGSoG Dissertation Series, nr 35 (2013)

Sepideh Yousefzadeh Faal Deghati

Childhoods Embargoed: Constructing and Reconstructing Multidimensional Child Poverty 
in Iran 1984-2009

MGSoG Dissertation Series, nr 34 (2013)

Robert Bauchmüller

Investing in Early Childhood Care and Education:

The Impact of Quality on Inequality

MGSoG Dissertation Series, nr 33 (2013)

Martin Rehm

Unified Yet Separated

Empirical Study on the Impact of Hierarchical Positions within Communities of Learning

MGSoG Dissertation Series, nr 32 (2013)

Dorcas Mbuvi

Utility Reforms and Performance of the Urban Water Sector in Africa

MGSoG Dissertation Series, nr 31 (2012)

Lina Salanauskaite

Distributional Impacts of Public Policies: Essays in Ex-Ante and Ex-Post Evaluation

MGSoG Dissertation Series, nr 30 (2012)

Esther Schüring

To Condition or not is that the Question?

An Analysis of the Effectiveness of Ex-Ante and Ex-Post Conditionality in Social Cash Transfer Programs

MGSoG Dissertation Series, nr 29 (2012)

Joe Abah

Strong Organisations in Weak States

Atypical Public Sector Performance in Dysfunctional Environments

MGSoG Dissertation Series, nr 28 (2012)

Zina Samih Nimeh

Social Citizenship Rights: Inequality and Exclusion

MGSoG Dissertation Series, nr 27 (2012)

Lenka Eisenhamerov

Legitimacy of Humanitarian Military Intervention

MGSoG Dissertation Series, nr 26 (2011)

Sonila Tomini

Informal Payments for Health Care Services in Albania

MGSoG Dissertation Series, nr 25 (2011)

Jinjing Li

Dynamic Microsimulation in Public Policy Evaluation

MGSoG Dissertation Series, nr 24 (2011)

Aziz Atamanov

Rural Nonfarm Employment and International Migration as Alternatives to Agricultural Employment: The Case of Kyrgyztan

MGSoG Dissertation Series, nr 23 (2011) 
Frieda Vandeninden

Poverty Alleviation: Aid and Social Pensions

MGSoG Dissertation Series, nr 22 (2011)

Juliana Nyasha Tirivayi

The Welfare Effects of Integrating AIDS Treatment with Food Transfers:

Evidence from Zambia

MGSoG Dissertation Series, nr 21 (2011)

Agnieska Ewa Sowa

Whos Left Behind? Social Dimensions of Health Transition and Utilization of Medical

Care in Poland

MGSoG Dissertation Series, nr 20 (2011)

Emmanaouil Sfakianakis

The Role of Private Actors in the Provision of Public Goods with Applications to Infrastructure and Financial Stability

MGSoG Dissertation Series, nr 19 (2011)

Siu Hing Lo

White Collars Green Sleeves

An Interonganizational Compariso of Deteminants of Energie-Related Behaviors among Office Workers

MGSoG Dissertation Series, nr 18 (2011)

Treena $\mathrm{Wu}$

Constraints to Human Capital Investment in Developing Countries:

Using the Asian Financial Crisis in Indonesia as a Natural Experiment

MGSoG Dissertation Series, nr 17 (2011)

Henry Espinoza Pea

Impact Evaluation of a Job-Training Programme for Disadvantaged Youths:

The Case of Projoven

MGSoG Dissertation Series, nr 16 (2011)

Florian Tomini

Between Family and Friends

Understanding the Interdependency of Private Transfers

MGSoG Dissertation Series, nr 15 (2010)

Michal Polalowski

The Institutional Transformation of Social Policy in East Central Europe:

Poland and Hungary in comparative and historical perspective

MGSoG Dissertation Series, nr 14 (2010)

Maha Ahmed

Defining, Measuring and Adressing Vulnerability:

The Case of Post Conflict Environments

MGSoG Dissertation Series, nr 13 (2010)

Pascal Beckers

Local Space and Economic Success 
The role of spatial segregation of migrants in the Netherlands

MGSoG Dissertation Series, nr 12 (2010)

Victor Cebotari

Complicting Demands in Ethnically Diverse Societies

Ethnopolitical Contention and Identity Values in Europe

MGSoG Dissertation Series, nr 11 (2010)

Dennis Gyllensporre

Competing and Complementary Perspectives on the EU as a Crisis Management Actor: An Examination of the Common Security and Defence Policy through the Lenses of Idealism and Realism

MGSoG Dissertation Series, nr 10 (2010)

Judit Vall Castello

Business Cycle and Policy Effects on Labour Market Transitions of Older and Disabled Workers in Spain

MGSoG Dissertation Series, nr. 9 (2010)

Keetie Roelen

False Positives or Hidden Dimentions: the definition and measurement of child poverty MGSoG Dissertation Series, nr. 8 (2010)

Denisa Maria Sologon

Earning Dynamics in Europe

MGSoG Dissertation Series, nr. 7 (2010)

Melissa Siegel

Money and Mobility: Migration and Remittances

MGSoG Dissertation Series, nr. 6 (2010)

Jessica S. Hagen-Zanker

Modest Expectations: Causes and effects of migration on migrant households in source countries

MGSoG Dissertation Series, nr. 5 (2010)

Mirtha R. Muniz Castillo

Human Development and Autonomy in Project Aid: Experiences from four bilateral projects in Nigaragua and El Salvador

MGSoG Dissertation Series, nr. 4 (2009)

Christiane Arndt

Governance Indicators

MGSoG Dissertation Series, nr. 3 (2009)

Britta Augsburg

Microfinance. Greater Good or Lesser Evil?

MGSoG Dissertation Series, nr. 2 (2009)

Geranda Notten

Measuring and Managing Poverty Risks

MGSoG Dissertation Series, nr. 1 (2008) 
The Maastricht Graduate School of Governance (MGSoG) was founded in September 2004 at Maastricht University. The mission of the School is to train specialists who combine a high level of academic scholarship with leadership, in order to strengthen democratic governance in domestic and international organizations, by focusing on policy analysis, risk assessment, policy design, monitoring and evaluation, and methodologies and techniques of policy research.

MGSoG provides multi-disciplinary top-academic training in the heart of Europe. This is achieved by building on the academic resources of the different faculties at Maastricht University as well as those of several foreign partners. From 2011 onwards, the School has become part of the United Nations University, strengthening further its international training and research network while building on the expertise of UNU-MERIT the Maastricht based research institute of the UNU. To guarantee both high academic quality and policy relevance, the MGSoG is closely involved with an extensive academic and professional network, including highly recognized organizations such as the OECD, ILO, UNDP, WB, IMF and EU. 